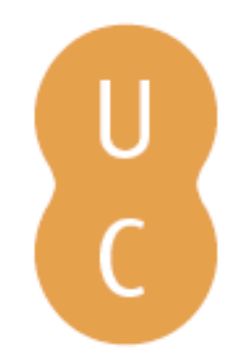

\title{
pommalina
}

\section{Francisco Manuel de Melo, historiador}

\author{
Autor(es): $\quad$ Oliveira, António de
}

Publicado por: Imprensa da Universidade de Coimbra; Ediciones Universidad

URL

persistente: URI:http://hdl.handle.net/10316.2/31516

DOI: $\quad$ DOI:http://dx.doi.org/10.14195/978-989-26-0245-5_11

Accessed : $\quad$ 26-Apr-2023 05:52:46

A navegação consulta e descarregamento dos títulos inseridos nas Bibliotecas Digitais UC Digitalis, UC Pombalina e UC Impactum, pressupõem a aceitação plena e sem reservas dos Termos e Condições de Uso destas Bibliotecas Digitais, disponíveis em https://digitalis.uc.pt/pt-pt/termos.

Conforme exposto nos referidos Termos e Condições de Uso, o descarregamento de títulos de acesso restrito requer uma licença válida de autorização devendo o utilizador aceder ao(s) documento(s) a partir de um endereço de IP da instituição detentora da supramencionada licença.

Ao utilizador é apenas permitido o descarregamento para uso pessoal, pelo que o emprego do(s) título(s) descarregado(s) para outro fim, designadamente comercial, carece de autorização do respetivo autor ou editor da obra.

Na medida em que todas as obras da UC Digitalis se encontram protegidas pelo Código do Direito de Autor e Direitos Conexos e demais legislação aplicável, toda a cópia, parcial ou total, deste documento, nos casos em que é legalmente admitida, deverá conter ou fazer-se acompanhar por este aviso. 
Marta Teixeira Anacleto

Sara Augusto

Zulmira Santos

Coordenação

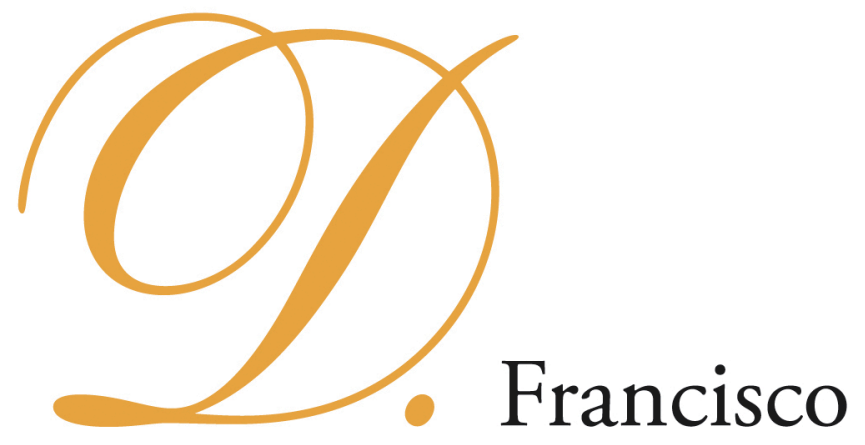

Manuel de Melo e o

Barroco Peninsular 


\title{
EDIĈ̣̃O
}

Imprensa da Universidade de Coimbra Ediciones Universidad Salamanca

\section{COORDENAÇÃo EDITORIAL}

Imprensa da Universidade de Coimbra

URL: http://www.uc.pt/imprensa_uc

Vendas online: http://www.livrariadaimprensa.com

\section{CONCEPÇÃO GRÁFICA}

António Barros

\section{REVISÃO TEXTO}

Sara Augusto

\author{
Pré-Impressão, Impressão e ACABamento \\ www.artipol.net
}

\section{IS B N}

978-989-26-0044-4 (Portugal)

978-84-7800-194-1 (Espanha)

DEPósito LEGAL

$311680 / 10$

OBRA PUBlicada COM O APOIO DE:

FCT Fundação para a Ciência e a Tecnologia

MINISTÉRIO DA CIÊNCIA, TECNOLOCIA E ENSINO SUPERIOR Portugal

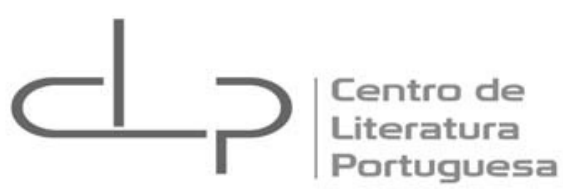

A presente publicação insere-se no Grupo "Poéticas" (coordenação de Marta Teixeira Anacleto) do Centro de Literatura Portuguesa, Unidade de I\&D financiada pela Fundação para a Ciência e a Tecnologia, ao abrigo do Programa Operacional Ciência e Inovação 2010.

(C) Agosto 2010

IMPRENSA DA UNIVERSIDADE DE COIMBRA

EDICIONES UNIVERSIDAD DE SALAMANCA 
Marta Teixeira Anacleto

Sara Augusto

Zulmira Santos

Coordenação

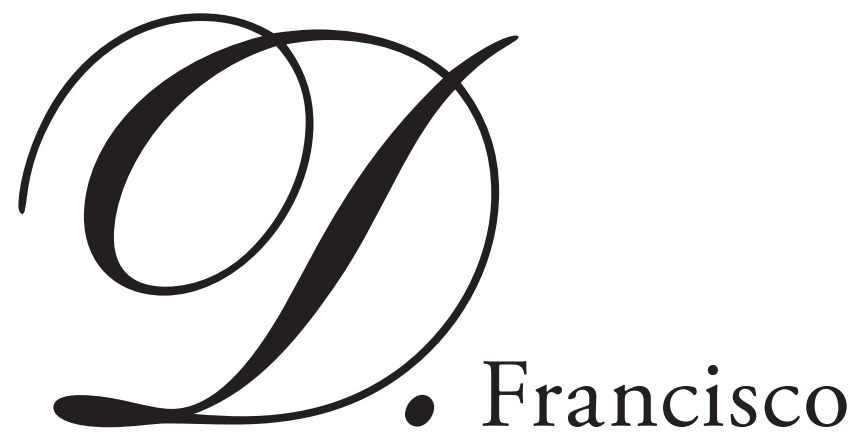

Manuel de Melo e o Barroco Peninsular

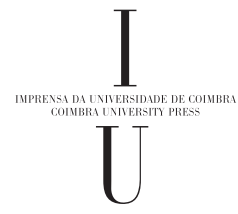


PARTE III

MODALIDADES DE ESCRITA DO BARROCO EM D. Francisco Manuel de Melo 


\section{António de Oliveira \\ Universidade de Coimbra}

\section{FRANCISCO MANUEL DE MELO, HISTORIADOR}

1.

As concepçóes historiográficas de D. Francisco Manuel de Melo têm sido estudadas com o auxílio de conceitos operatórios diversos, na senda evolutiva da teorização da História, não sendo tarefa fácil representar mais uma vez o autor ${ }^{1}$.

Lembrarei, por isso, a meu favor, a expressáo de Umberto Eco, "como este recordou a si e a todos", ao explicar o porquê de O Nome da Rosa: "os livros falam sempre de outros livros e qualquer história conta uma história já contada» ${ }^{2}$, pelo que em boa parte se tem de

*Publicado na revista Península, 9, 2010. A presente versão contém modificaçôes.

${ }^{1}$ Vide Maria Teresa Amado, A representação do poder em Francisco Manuel de Melo. Coimbra: [s. n.], 1987, dissertação de mestrado policopiada, 2 vols., sendo o segundo um apêndice documental; Maria Teresa Amado e João Luís Lisboa, Teoria da História em Francisco Manuel de Melo. [Lisboa]: Plátano Editora, 1983; Claude Maffre, «La Guerra de Cataluña: Don Francisco Manuel de Melo, écrivan et philosophe de l'histoire», Arquivos do Centro Cultural Português. Paris: FCG, vol. III (1971), pp. 371-400; Carminda Nogueira de Castro, O conceito de História em D. Francisco Manuel de Melo e a questão da veracidade na "Guerra da Catalunha». Coimbra: [s. n.], 1948, dissertação de licenciatura policopiada; Joaquim Cândido da Fonseca, D. Francisco Manuel de Melo, historiador: subsídios para um estudo completo. Lisboa: [s. n.], 1937, 63 fl., dissertaçâo de licenciatura policopiada, obra que não tive oportunidade de consultar; uma outra dissertação de licenciatura, apresentada na Universidade Complutense, Madrid, deve-se a Isidro Matías Cerro, Historiografia del siglo XVII. Francisco Manuel de Melo: Historia de los movimientos, separación y guerra de Cataluña (encontra-se citada e aproveita por José Cepeda Adán, «La historiografía”, in El siglo del Quijote 1580-1680. I. Religión. Filosofía. Ciencia. (Historia de la Cultura Española «Ramón Menéndez Pidal», dir. por Jover Zamora, José María). Madrid: Espasa, 1996, p. 81, a qual năo pudemos consultar. A problemática foi igualmente considerada pelos autores que estudaram a sua obra geral, nomeadamente nas diversas histórias da Literatura, ou, especificamente, pelos autores que editaram textos históricos, alguns dos quais vão indicados nas notas seguintes. Para o enquadramento historiográfico tenham-se em conta as histórias da historiografia, algumas delas adiante citadas. Destaque para a dissertaçáo de doutoramento de Maria Teresa Amado, A Lingua do Ver na Espanha dos Áustrias: criação de memória e fixação de ideais. Évora: [s. n.], 1997.

${ }^{2}$ Umberto Eco, Porque «O nome da Rosa»? Tradução de Maria Luísa Rodrigues de Freitas. Lisboa: Difel, 1991, 2a ed., pp. 20-21. De modo semelhante havia-se já pronunciado D. Francisco Manuel de Melo no domínio dos versos (Benjamin Nicolaas Teensma, Don Francisco Manuel de Melo, 1608-1666: inventario general de sus ideas. Gravenhage: Martinus Nijhoff, 1966, p. 115; D. Francisco Manuel de Melo, «Hospital das Letras», in Apólogos dialogais. Prefácios e notas do Prof. José Pereira Tavares (Vol. II, Escritório Avarento. Hospital das Letras. Lisboa: Livraria Sá da Costa, 1959, p. 124). Seguimos esta edição para as referências destes apólogos, mas tivemos em conta também, no que diz respeito ao Hospital das Letras, a edição de Jean Colomès. 
reencontrar o já dito, como por volta de 1637, aliás, já Descartes reconhecia saber desde o tempo do colégio, no tocante às diferenças de «opinióes dos mais doutos» ${ }^{3}$.

D. Francisco Manuel ensinou a transformar a herança em novo saber, dando vida nova a alguns aspectos do conhecimento precedente. Mas fê-lo recorrendo, para além da reelaboração de síntese interpretativa, à sua formosa expressão literária, que o estudo de algumas das fontes historiográficas que utilizou permite ajuizar, náo deixando de recordar no entanto, precisamente a propósito do acrescento do saber, que «não somos mais próximos dos outros de que nós mesmos» ${ }^{4}$.

Pelo meu lado, procurarei percorrer, através de alguns pontos de referência, um caminho de síntese dos marcos historiográficos tradicionais aos termos inovadores de transição assumidos por D. Francisco Manuel de Melo.

O amor aos versos, em D. Francisco Manuel de Melo, remonta à idade da razão, como ele próprio recorda ${ }^{5}$. O afecto à História teria igualmente despontado cedo, certamente, dado que fazia parte, do ensino médio que frequentou, a cronologia, a história e a geografia, entre outras disciplinas visando a erudição ${ }^{6}$, mas só tardiamente, já homem maduro, se afirmou como historiador ${ }^{7}$. Sintomaticamente, no entanto, os primeiros sonetos que publica, em 1628, retomam o tema da morte de D. Inês de Castro, unindo história e poética e, ao mesmo tempo, o espaço ibérico num momento de «hispanização do mito» que celebra, como acentuou Renata Belardinelli ${ }^{8}$. O tratamento poético de assuntos históricos continuou-o ao longo da vida em múltiplas criaçóes, como os «romances historiales» e compo-

\footnotetext{
${ }^{3}$ Renato Descartes, Discurso do Método e tratado das paixóes da alma. Tradução, prefácio e notas pelo prof. Newton de Macedo. Lisboa: Livraria Sá da Costa, 1943, p. 19.

${ }^{4}$ Hospital das Letras, p. 208.

${ }^{5}$ D. Francisco Manuel de Melo, Obras Métricas. Edição coordenada por Maria Lucília Gonçalves Pires e José Adriano de Freitas Carvalho. Volume I. Braga: Ediçōes APPCDM, 2006, p. 13.

${ }^{6}$ Francisco Rodrigues, A formação intelectual do jesuita. Leis e factos. Porto: Livraria Magalhães e Moniz, 1917, pp. 45-46; Margarida Miranda, "A Ratio Studiorum ou a institucionalização dos estudos humanísticos», Biblos. Coimbra: Faculdade de Letras. $2^{a}$ série, vol. V (2007), p. 122. D. Francisco Manuel de Melo, se efectivamente seguiu os estudos dos jesuítas, frequentou também o ensino superior, na parte correspondente a Filosofia (Filosofia, Matemática e Ciências Naturais), cujo ciclo, com Humanidades (Gramática, Humanidades e Retórica), deveria somar oito anos e sete meses de estudo (Miguel Correia Monteiro, Os jesuitas e o ensino médio. Lisboa: [s. n.], 2008, policopiado, cap. «Organização dos estudos inferiores»). D. Francisco alistou-se como militar voluntário aos 17 anos, seguindo então a carreira das armas, devendo ter ficado fora do plano curricular, provavelmente, apenas o ciclo de Teologia, o qual durava quatro anos.

${ }^{7}$ Aos 17 anos teria escrito, segundo Barbosa Machado, uma obra intitulada Concordancias mathematicas de antigas e modernas hypotesis (Diogo Barbosa Machado, Bibliotheca Lusitana Tomo II. Coimbra: Atlântida Editora, 1966, p. 187; informação seguida por Edgar Prestage, D. Francisco Manuel de Mello. Esboço biographico (ediçáo facsimilada da de 1914). Lisboa: Fenda, 1996, pp. 33 e 597.

${ }^{8}$ Renata Cusmai Belardinelli, «I Doze sonetos per la morte di Ines de Castro di don Francisco Manuel de Melo, introduzione, lettura critica, commento e glossario [...]», Arquivos do Centro Cultural Português. Paris: FCG. Vol. XVII, (1982), p. 854.
} 
siçóes referidas a personalidades e actos históricos, denominando um dos conjuntos «La Lira de Clío»?

Ao tempo em que publicou Doze sonetos, como se depreende da futura narrativa do naufrágio de 1627, já estava desperto às relaçóes dos acontecimentos e a captá-los na tenaz memória que possuía, bem treinada desde o tempo de escolar, como impunham os métodos pedagógicos de então, não sendo imaginação vê-lo reunir documentação que corria manuscrita ou impressa sobre os grandes acontecimentos ${ }^{10}$. Que estava atento a eles, mostrou-o também por volta de meados de 1631 ou pouco depois, ao servir-se da pena e da tinta para defender a honra da nobreza, em perigo de se tornar tributária ${ }^{11}$ através de um disfarçado imposto, que a própria nobreza qualificava de «indecente», as denominadas meias anatas ${ }^{12}$.

${ }^{9}$ D. Francisco Manuel de Melo, Obras Métricas, II vol., pp. 811 e s., de interesse para a história coeva do Autor. Muitas outras composiçôes suas podem servir de fontes históricas, algumas das quais se encontram referidas em Edgar Prestage, D. Francisco Manuel de Mello, pp. 608-609. Aspetos das relações entre poesia e história in Helena Barbas, "Laura de Anfriso" de Manuel da Veiga Tagarro. Poesia e História. Lisboa: Faculdade de Ciências Sociais e Humanas, 1990, dissertação de mestrado em Estudos Literários, capítulo IV. Consultei a versão http:/www.fcsh.unl.p/ /docentes/hbarbas/Tagarro HB.htm.

${ }^{10}$ Francisco Manuel de Melo, Epanaphoras de varia historia portugueza [...], edição fac-similada da de 1660, com introdução e apêndice documental de Joel Serrão. Lisboa: [s. n.], 1975 (?), p. 157; idem, Hospital das Letras, p. 194.

11 Trata-se do primeiro exemplar conhecido da sua prosa, no ajuizar de Edgar Prestage, o qual se intitula Memorial ofreçido al Rey nuestro Señor sobre el donativo que se trata pedir a la nobleza del reyno de Portugal, o qual ficou por concluir (Edgar Prestage, D. Francisco Manuel de Mello, pp. 57-58). Embora tivéssemos consultado o cód. 7674, da Biblioteca Nacional de Portugal, onde o manuscrito se encontra, seguimos, na parte da transcição, a que foi reproduzida por Maria Teresa Amado, A Representação do Poder..., II vol., pp. 72-85. Pouco depois, ter-se-ia oposto a uma obra de João Pinto Ribeiro, Discurso sobre os fidalgos, e soldados portugueses não militarem em conquistas alheas desta Coroa. Lisboa: Pedro Craesbeek, 1632 (Francisco Manuel de Melo; Tácito português. Vida, morte, dittos e feitos de El Rey Dom João IV de Portugal. Prefácio e leitura do manuscrito por Raul Rego. Lisboa: Livraria Sá da Costa, 1995, p. 75). Para a censura da obra de João Pinto Ribeiro, referências em Maria Teresa Esteves Payan Martins, A censura literária em Portugal nos séculos XVII e XVIII. Lisboa: Fundação Calouste Gulbenkian / Fundação para a Ciência e Tecnologia, 2001, p. 374.

${ }^{12}$ No estado em que se encontra, o escrito, como declara o autor em português, depois da cópia trancada do texto, «serve para ver algun prinçipio da nobreza e sua origem». O que o texto pretende evidenciar é a honra detida pela nobreza, mostrando com exemplos como esta sempre assim foi considerada das origens ao tempo de Filipe IV, com enquadramento inicial da história geral. Seguir-se-ia, por certo, a denominação do tributo e o desenvolvimento de «el justissimo desconsuelo con que la Nobleza deste Reyno se alla en la ocasion pressente quando con ymperio se le pide un cassi pecho, dorado con la vanidad, de alguno modesto nombre». Na anotaçáo final do escrito sobre el donativo, o autor declarou: «Mais tenho escrito deste papel mas pasouse lhe a sezão e a mi a curiozidade».

Ser «pechero», tributário, era uma desonra. Este quase pecho deverá ser a meia anata dos ofícios, começada a executar, em princípio, em 21 de Maio de 1631, cuja preparação vinha de 1629. O seu regimento é de 12 de Setembro seguinte (José Justino de Andrade e Silva, Collecção chronologica da legislação portuguesa compilada e anotada por [...] 1627-1633. Lisboa: Imprensa de F. X. de Sousa, 1855, pp. 203-204 e 220-225). O Memorial deveria ter surgido depois de uma destas datas. Neste mesmo ano foram lançadas outras imposiçóes, como a repartição por empréstimo dos primeiros 500000 cruzados, pedidos pelo poder régio em nome da defesa do ultramar, mas náo passou de uma «repartição vocal» em relação à nobreza, a qual se não dispôs a cumprir, nem genericamente cumpriu. (Vide António de Oliveira, Poder e oposição política em Portugal no periodo filipino (1580-1640). Lisboa: Difel, 1991, pp. 118 s. e 132 s.; idem, "Levantamentos populares no Algarve em 1637-1638», in idem, Movimentos sociais e poder em Portugal no século XVII. Coimbra: Faculdade de Letras / Instituto de História Económica e Social, 2002, pp. 525-527). Depois de 31 de Janeiro de 1627, data da suspensáo de pagamentos por parte da coroa castelhana, surgiu em Portugal uma epidemia de tributos até 1637. Em outras ocasiôes, para além de 1631-1632, D. Francisco Manuel teria tido igualmente oportunidade de se pronunciar sobre as novas contribuiçóes da nobreza. 
Os sucessos ocorridos em Portugal em 1637 e 1638, por sua vez, e na continuação da epidemia tributária que nele grassava depois da primeira «bancarrota» de Filipe IV, em Janeiro de $1627^{13}$, e da política de reputaçáo entáo seguida, exigindo cada vez mais homens e dinheiro ${ }^{14}$, teriam acicatado o desejo de D. Francisco Manuel se dedicar à escrita de temas políticos e militares, publicando em 1638 Política militar, en avisos de generales ${ }^{15}$, depois de em 1636 haver já solicitado a Francisco de Quevedo a crítica do manuscrito, como parece, numa atitude de procurar avaliar a prosa que elaborava por quem tinha autoridade profissional, antes de expô-la ao público ${ }^{16}$. Solicitude que tomou quando recebeu num aquartelamento militar de Flandres o Nuno Álvares Pereira de Méndez Silva (1607-1670) ${ }^{17}$, enviado pelo autor, ou quando se pôs ele próprio a tentar escrever a história de Portugal sob novos canones ${ }^{18}$. Era bastante comum, com efeito, «correrem os manuscritos» antes da impressão, como fez também, por seu lado, para indicar apenas mais um exemplo, João Salgado Araújo ${ }^{19}$.

\footnotetext{
${ }^{13}$ Já em 1596 se tinha verificado uma outra suspensão de pagamentos. (Vide Modesto Ulloa, La hacienda real de Castilla en el reinado de Felipe II. Madrid. Fundación Universitaria Española, 1977, p. 818; Carlos Xavier de Carlos Morales, Felipe II: el imperio en bancarrota. la hacienda real de Castilla y los negocios financieros del Rey Prudente. Madrid: Editorial Dilema, 2008, pp. 283 s.).

${ }^{14}$ «Tres são os fundamentos principaes, sobre os quaes se estriba a machina do governo politico, a que chamão, razão de estado, conselho, forças e reputação" (Sebastiāo César de Meneses, Summa politica: offerecida ao principe D. Theodosio Nosso Senhor pelo bispo conde eleito [...]. Lisboa: por Antonio Alvarez, 1649, p. 1).

${ }^{15}$ Politica militar en avisos de generales. Introdução e notas de Pedro de Brito. [S. 1.], Granito, 2000. Pelo menos um exemplar desta obra encontrava-se entre os livros de D. Pedro II, em 4º, pergaminho, o qual foi avaliado em 400 réis. (Virgínia Rau e Eduardo Borges Nunes, Inventário post-mortem del rei-Rei D. Pedro II. Edição e introdução de [...]. Lisboa: Instituto de Alta Cultura, 1969).

${ }^{16}$ A carta dirigida a Quevedo, datada de Madrid aos 4 de Outubro de 1636, refere apenas o envio de um «discurso». Mas acrescenta: "yo envío a V. M. este mi primero trabajo, por que se sirva de enviármele de suerte que no tema despues de su emmenda la censura de otro" (Francisco Manuel de Melo, Cartas Familiares. Prefácio e notas de Maria da Conceição Morais Sarmento. Lisboa: Imprensa Nacional / Casa da Moeda, 1980, p. 58). Colomès supôs tratar-se da Politica Militar ou do Memorial [...] sobre o donativo que se trata de pedir a la nobleça del Reyno de Portugal. Este trabalho não estava acabado e, tal como se conhece hoje, não se encontrava em condiçóes de ser enviado para apreciação. Sobre as relaçóes entre D. Francisco Manuel de Melo e Quevedo, vide Jean Colomès, "Sur les relations de D. Francisco Manuel de Melo avec Quevedo», Arquivos do Centro Cultural Português, II. Paris: FCG, (1970), pp. 573-577; Antonio Bernat Vistarini, Francisco Manuel de Melo: 1608-1666: Textos y contextos del Barroco peninsular. Palma: Universitat de les Illes Baleares, 1992, pp. 77-114.
}

${ }^{17}$ Rodrigo Méndez Silva, Vida y hechos heroicos del gran condestable de Portugal D. Nuño Alvarez Pereyra [...]. Madrid: por Juan Sanchez, a costa de Pedro Coelho, mercador de libros, 1640. Publicada com carta introdutória de Francisco Manuel de Melo, a qual também se encontra, em português, em Cartas..., pp. 84-87. É nesta carta que Melo indica ter comunicado o texto à Universidade de Lovaina, "aos sujeitos mais doutos que ali concorrem, principalmente em a História Universal e Cadeira de Boas Letras, que hoje ocupa o sapientíssimo Erício Puteano, sucesor e émulo de Justo Lípsio, que igualmente com o senhor Bispo de Ypre, ilustríssimo pelos seus ilustrres escritos, ficaram igualmente agradados deste de V. M.».

${ }^{18}$ Em referência aos dois primeiros livros de D. Teodósio, pede em 18 de Dezembro de 1648: «a grande mercê que eu lhe pedira fora os mandasse ver pelos professores de História e que V. M. nisso tivera parte, como seu estudo e engenho merecem» (Cartas.., p. 215). Atitude também tomada, por exemplo, por Gaspar Barreiros, em 1557, em relação a "Marcos de Bethania, mestre em Santa Theologia", a propósito das Censuras de Gaspar Barreiros sobre quatro livros intitulados em M. Portio Catam de Originibus, em Beroso Chaldeo, em Manethon Aegyptio, \& em Q. Fabio Pictor Romano. Coimbra: per Joam Alvares, 1561.

${ }^{19}$ A propósito da sua «historia general y nobleza del Reyno de Galiza y de las Provincias de entre Duero e Miño, y Traslommontes», João Salgado Araújo «quise a imitación de algunos escritores, embiar fuera una muestra della, a descubrir el aplauso que tendrá». (Fernando Bouza, "Dar Galicia y el gallego a la imprenta. As Gallegadas y $A$ História de Galicia de Lobariñas Feijoo, la Verdadera Descripción de Ojea y algunas iniciativas historiográficas de la primera mitad del Siglo XVII», Obradoiro de Historia Moderna. Santiago de Compostela: USC, no 18 (2009), p. 14. 
A sua fama de escritor estava já firmada por esta altura, dado que em 1639, ao chegar a Flandres, a seguir à batalha do Canal, o governador ordenou-lhe que fizesse uma relação do sucedido ${ }^{20}$ e, no ano seguinte, foi encarregado «de pôr em memória os progressos» da nova guerra de Catalunha, em que estava a participar ${ }^{21}$.

Como é bem sabido, só em 1645 conseguiu concluir e publicar, sob pseudónimo, a Guerra de Cataluña $a^{22}$ a sua obra histórica prima no tempo de ediçáo e no valor literário, depois das vicissitudes da prisão em Madrid e de se ter fixado em Portugal com a Restauraçáa ${ }^{23}$, tempo que de novo o aprisionou, mantendo-o em custódia, em mais do que um regime, de 1644 a $1662^{24}$. Foi neste período que pôde elaborar uma boa parte da sua obra, de cujo elenco se poderiam extrair em 1664, entre História ${ }^{25}$ e Política, 39 títulos, dos quais se destacam 8 impressos em sua vida e 5 posteriormente ${ }^{26}$.

${ }^{20}$ Francisco Manuel de Melo, Epanaphoras, p. 353. D. Francisco Manuel recrutou em 1639 um dos terços para Flandres, tendo chegado ao destino depois de sofrer a derrota da armada no Canal de Inglaterra, como dramaticamente descreve (Epanaphora Belica). Arregimentou parte do terço no Norte do país e o resto em Castela. Foram entâo mandados recrutar quatro terços em Portugal. A D. Francisco Manuel não passou despercebido o facto, vacilando entre supor que havia necessidade militar ou por motivo das «revoluçôes» (sic) acontecidas pouco antes, em 1637-1638 (Epanaphoras, pp. 359 s.). O «Norte do país», onde D. Francisco Manuel procedeu ao levantamento de tropa, compreendeu «Beira, Douro e Minho, Trás-os-Montes e parte de Alentejo». Para enquadramento com a actividade militar em Galiza neste momento, vide María del Carmen Saavedra Vázquez, Galicia en el camiño de Flandes: actividad militar, economía y sociedad en la España noratlántica, 1656-1648. Sada, A Coruña: Ediciós do Castro, 1996, pp. 179 s. Cf. infra, n. 340.

${ }^{21}$ Hospital das Letras, p. 194. Da Flandres passou a Madrid e, daqui, para a Junta da Cantábria (Vitória), no contexto da guerra contra a França (Edgar Prestage, D. Francisco Manuel de Mello, p. 134). Em 5 de Junho de 1640 devia estar em Madrid, tempo de despachos relativos a mercês que solicitou pelos serviços prestados (Archivo Historico de Madrid, Estado, liv. 372; Archivo General de Simancas, Guerra Antigua, m. 1334). Nesta data, com efeito, têm despacho, quanto ao que requereu: «hidalguia y habito que pide en Portugal», por motivo de ajuda de custo: se remeta à Junta de Portugal, em Madrid; sobre remuneração de serviços atrasados, remete-se para a mesma Junta; quanto "ao de tesoureiro»: «no ha lugar por que estan providos todos»; sobre "Lo del govierno de Bayona em Galicia se remita al Consejo de Guerra, aonde toca; se quiser ir servir, «se le de el sueldo que le toca por su reformacion en Flandes o Milan». (AHM, Estado, liv. 372, registo de consultas). Sobre a passagem da comenda em Portugal, ainda em 1640, doc. em Edgar Prestage, D. Francisco Manuel de Mello, p. 471, doc, $\mathrm{n}^{\circ}$ 45, de 23 de Novembro de 1640. Já em 10 de Dezembro de 1634 havia obtido um alvará de promessa de comenda (AN/TT, Chancelaria da Ordem de Cristo, liv. 28, fl. 3v). A mercê só veio a concretizar-se em 1643 (Edgar Prestage, D. Francisco Manuel de Mello, p. 490).

${ }^{22}$ Precisamente por esta altura, D. Francisco Manuel apresenta-se a um soldado e historiador cheio de fama, o conde Galeazzo Gualdo Priorato (1606-1678), como historiador de recente data, não obstante leitor de longo tempo dos temas históricos (Cartas, p. 101, datada de 11 de Junho de 1645; Edgar Prestage, D. Francisco Manuel de Mello, pp. 211-212;). Em 1654 repete a mesma ideia, dirigindo-se a um amigo (Epanaphoras, p. 274 e também pp. 349-350, 156-157 e 274 sobre matéria afim). Sobre Gualdo Priorato, vide infra, n. 28.

${ }^{23}$ Vide, a propósito, Edgar Prestage, D. Francisco Manuel de Mello, pp. 133 e s. Em Madrid solicita diversas mercês em virtude da nova situação política portuguesa. Em 2 de Março de 1641, a Junta de Execuçáo detalha as recompensas concedidas a D. Francisco Manuel de Melo (Memorial Histórico Españo., vol. XXV, p. 669; Edgar Prestage, D. Francisco Manuel de Mello, pp. 147 s., com desenvolvimento e publicação de alguns documentos, incluindo o do referido Memorial Histórico Español).

${ }^{24}$ Para as vicissitudes deste período, vide Edgar Prestage, D. Franciso Manuel de Mello, pp. 185 s.

${ }^{25}$ Incluindo os subgéneros. Muitos dos seus trabalhos, incluindo os de natureza histórica, conhecem-se apenas, no momento, pelo elenco geral dos seus títulos, como é bem sabido. Para a sistematização dos de índole historiográfica não podemos contar com a publicação de um conjunto de Obras Históricas por parte do Autor, o qual prometeu aos seus 
A maior parte dos textos históricos que redigiu dizem respeito à história do seu tempo. Escrevia, como dizia do conde Gualdo Priorato (1606-1678), de «los vivos negocios de nuestros dias», «de homens viventes», como no caso da Epanáfora Triunfante ${ }^{27}$, embora acrescente, por vezes, tratar de acontecimentos «do seu tempo mas já passado» ${ }^{28}$. História difícil de realizar em qualquer tempo de todos os tempos, porque até «a sombra dos vivos se respeitam», «enquanto as cinzas dos mortos não se temem», como dirá em 1669 Fernando Correia de Lacerda ${ }^{29}$, que foi seu amigo, mas que Francisco Manuel de Melo soube bem contornar, sem deixar de manifestar o espírito crítico que de modo geral exerceu, tendo ele próprio feito parte de um grupo de autores encarregados das «repreensóes e emenda de vícios e costumes da república ${ }^{30}$, cuja memória simbolicamente agrupou à sua volta e a seu modo no Hospital das Letras, embora nem sempre, pelo menos quanto à historiografia, tenha tido razão ou, pelo menos, estivesse bem informado ${ }^{31}$.

leitores, no primeiro de Abril de 1665. Estava então a cumprir um plano editorial que vinha pelo menos de 1664, devendo constituir o conjunto das obras históricas o primeiro volume a aparecer depois das Obras Métricas (Francisco Manuel de Melo, Obras Métricas, vol. I, p. 8). A morte, ocorrida pouco depois, em 28 de Agosto de 1666, não lhe permitiu continuar a concretização do plano inicial, de que também fariam parte as Obras Políticas, para além de outros conjuntos cujas nomenclaturas deixou exaradas (D. Francisco Manuel de Melo, Obras Morales de Don Francisco Manuel a la Serenissima Reyna Catalina Reyna de la Gran Bretaña. Parte Primera. Roma: por el Falco, 1664, nas duas páginas anteriores à «Tabla de los assuntos de la Vitoria del Hombre»). Foram entáo previstos 10 volumes, cujos conteúdos náo seriam, precisamente, os agora considerados, como se passou, por exemplo, com a edição das Obras Métricas e, eventualmente, poderia ocorrer com os próprios títulos gerais. Cf. Luís de Sá Fardilha, "Tempos e modos da edição lionesa das Obras Métricas, in Francisco Manuel de Melo, Obras Métricas, vol. I, p. XIX. «As obras históricas e / ou obras políticas» poderiam estar destinadas à oficina de "Juan Stanop», em Londres, segundo Teensma, Ocidente. Lisboa, vol. LXIV (Fev. 1963).

${ }^{26}$ Do elenco das suas obras consideradas inéditas constam muitos títulos que dizem respeito a temas históricos. Vide, para catálogo das suas obras, para além dos conjuntos apresentados por Edgar Prestage e revisitados por Teesnma (D. Francisco Manuel de Mello, 1608-1666. Varia bibliográfica. Lisboa: Separata da revista «Ocidente», vol. LXI, 1961); idem, Materiais novos para a bibliografia de Dom Francisco Manuel de Mello, ibidem, vol. LXIV (Fev. 1963), p. 94-99; Carolina Michäelis de Vasconcelos, D. Francisco Manuel de Melo. Notas relativas a manuscritos da Biblioteca da Universidade de Coimbra, II. Coimbra: Imprensa da Universidade, 1915, pp. 22-29. Vide também Teresa Amado, Representação do Poder, pp. 3 e s.

${ }^{27}$ Epanaphoras, p. 482.

${ }^{28}$ Epanaphoras, pp. 100-101. A oferta de a Guerra de Cataluña serviu-lhe de ensejo para solicitar troca de correspondência, oferecendo-se para enviar-lhe "as justas informaciones de los sucesos publicos de este Ocidente», com as quais bem poderia corrigir os erros contidos na segunda parte das suas Memórias Universais a propósito do tema da Epanáfora Bélica (Epanaphoras, p. 351). Vide supra, n. 22.

${ }^{29}$ Citado por Joaquim Veríssimo Serrão, A historiografia portuguesa, vol. II. Lisboa: Editorial Verbo, 1973, p. 204. («A Francisco Correa de Lacerda, Mestre de sua Alteza», dirigiu D. Francisco Manuel a Epistola V, «escrita em Parma, provavelmente na segunda metade de 1663», segundo Obras Métricas..., vol. II, p. 953). Perigo que vinha da Antiguidade: «Muy peligroso es escrivir las historias del siglo que corre, y del q ha poco que passo; por estar ainda vivos los descendientes de las personas de quen se trata» (Don Baltasar Álamos de Barrientos, Tacito español ilustrado con aforismos, por [...]. Madrid: por Luis Sãchez, 1614, p. 246).

${ }^{30}$ Hospital das Letras, p. 82.

${ }^{31}$ No Hospital das Letras, pp. 243 s., D. Francisco Manuel passa em revista uma longa série de historiógrafos, da Antiguidade ao seu tempo, mas nas páginas anteriores há referências a outros nomes que estão também ligados à escrita da História. As apreciações que faz de Ieronimo de Franchi Conestaggio, por exemplo, tanto no Hospital das Letras, pp. 128-129, como na Epanaphora Tragica, p. 158, foram rebatidas por Giacinto Manuppela, em contexto 
O estudo da história coeva, nomeadamente dos acontecimentos em que tomou parte ${ }^{32}$, constituiu uma decisão de gosto e um imperativo metodológico, para além de uma tendência historiográfica do momento, impulsionada já em Espanha, nos meados do século XVI, pelo cronista régio Juan Páez de Castro $^{33}$, não obstante as histórias gerais, com origens míticas, irem até aos inícios do século XVII, pelo menos em Portugal ${ }^{34}$.

A intensa actividade intelectual ajudou-o a vencer o tempo aprisionado, com manhâs enevoadas enquanto esteve nas torres que defendiam a barra de Lisboa, transformando-o em claro ócio criativo. As agruras do tempo e as grades do espaço marcaram, no entanto, o amante da liberdade e "peregrino do mundo", impondo limites e temas, pelo menos no campo historiográfico ${ }^{35}$.

Da história pátria começou precisamente por escrever aqueles sucessos, como afirmou em 1654, «cujas informaçoens, eu não pedisse ao estudo dos livros, \& só de minha lembrança facilmente os recebesse» ${ }^{36}$. O que significa, de certo modo, a prevalência do

alargado a outras apreciaçóes também erradas, Giacinto Manuppella, "A lenda negra de Jerónimo de Franchi Conestaggio e da sua Unione del regno di Portogallo alla corona di Castiglia (Génova, 1585)", Revista da Universidade de Coimbra. Coimbra: Universidade de Coimbra, vol. XXXI (1985), pp. 53-148. O artigo incorpora o essencial de dois outros trabalhos do mesmo autor, sendo um deles «Ieronimo de Franchi Conestaggio gentilhuomo genovese», in Miscelânea de Estudos em Honra do Prof. Hernâni Cidade. Lisboa: Faculdade de Letras da Universidade de Lisboa, 1957, pp. 216-287.

${ }^{32}$ Não esteve presente na "guerra brasílica», narrada em Restauração de Pernambuco (1654), estando ainda preso em Lisboa. A composição está datada de 1659 (já regressado do desterro do Brasil) e foi incluída nas Epanahoras sob o qualificativo de triunfante. Conhecia bem, no entanto, o assunto (Epanaphoras, p. 482).

33 Passar das origens e dos reis primitivos de Espanha para o presente, era um dos objectivos do referido cronista, no seu memorial intitulado De las cosas necesarias para escribir la historia, datado de 1555 (Pablo Fernández Albadalejo, «Materia de España y 'edificio' de historiografía. Algunas consideraciones sobre la década de 1540", in idem, Materia de España. Cultura política e identidad en la España moderna. Madrid: Marcial Pons, 2007, pp. 6263). Vide, também, Jenaro Costas Rodríguez, "La historiografía hispano-latina renascentista», in Humanismo y pervivencia del Mundo Clásico. Actas del I Simposio sobre Humanismo y Pervivencia del Mundo Clásico. Alcañiz, 8 a 11 de Mayo de 1990 / coord. José María Maestre, Joaquín Pascual Barea. Cádiz: Inst. de Est. Turolenses. Universidad de Cádiz, vol. I, 1993, pp. 53-54.

${ }^{34}$ Frei Bernardo de Brito (1569-1617), Monarchia Lusytana. Parte Primeira que contem as historias de Portugal desde a criação do mundo te o nascimento de nosso sñor Jesu Christo dirigida ao catholico rei Dó Philippe II do nome rei de Espanha emperador do novo mundo. Alcobaça: Mosteiro de Alcobaça, 1597. A segunda parte saiu em 1609. Os primeiros vinte livros da obra de Mariana, Juan (1536-1624, datas náo seguidas por todos os autores), Historiae de rebus Hispaniae lib. XXX foram publicados em Toledo em 1592 e a obra completa, em latim, em Mogúncia, 1605. O próprio Mariana havia traduzido para castelhano a obra, pelo que os últimos 10 livros sairam primeiro em língua espanhola (Historia General de España. Toledo: P. Rodriguez, 1601, 2 tomos). Mais tarde Mariana publica um Sumario da obra, o qual é então acrescentado até 1621. (Seguimos Fueter, Ed. Historia de la historiografía moderna. Buenos Aires: Editorial Nova, 1953, p. 248). Esta edição não tem referências bibliográficas para além de 1913. Uma resenha sobre Mariana, a obra e bibliografia, in Juan Mariana, Tratado contra los juegos públicos. José Luis Suárez García, ed. Granada: Editorial Universidad de Granada, 2004, pp. 21-39. Vide também José Cepeda Adán, «La historiografía», pp. 717 s. e 722 s.; Quintín Aldea Vaquero, Tomás Marín Martínez e José Vives Gatell, dirs., Diccionario de Historia Eclesiástica de España, tomo III. Madrid: Instituto Enrique Florez, 1973, pp. 1417-1418. Sobre histórias nacionais, vide Diogo Ramada Curto, $A$ cultura politica em Portugal (1578-1642). Comportamentos, ritos e negócios. Lisboa: [ s. n. ], 1994, pp. 350 s., dissertação de doutoramento policopiada.

\footnotetext{
${ }^{35}$ Cartas, p. 277.

${ }^{36}$ Epanaphoras, p. 274.
} 
«documento» contemporâneo, integrando-se na corrente nascente do criticismo ${ }^{37}$, embora a decisão tomada possa também espelhar, nas circunstâncias em que se encontrava, a dificuldade em efectuar investigaçóes de outra natureza. Facto, no entanto, que não significa que se tivesse servido apenas de informaçôes próprias, como é óbvio, ao longo da escrita da história.

Embora indique parcimoniosamente as fontes utilizadas, sinal suficiente para os que professam a história reconhecerem o que é ou não seu, segundo considera ${ }^{38}$, D. Francisco Manuel auto-avalia-se como "exigente em averiguar as origens e a verdade dos acontecimentos» ${ }^{39}$. O estudo das fontes que utilizou para compor a Guerra de Cataluña ${ }^{40}$ está feito e encontra-se começado trabalho semelhante para outras obras ${ }^{41}$, deparando-se-nos a publicação de documentos em a Epanáfora Política. Conhecem-se também, por outro lado, alguns dos fluxos de informação e de circulação de obras. E não se desconhece que para a elaboração de $D$. Teodósio foram aparentemente colocados à sua disposição, através de "Reais ordens», os «arquivos do Reino e Estados» ${ }^{42}$ e que se socorreu de múltiplas informações ${ }^{43}$,

${ }^{37}$ Em Espanha, o início da crítica histórica costuma marcar-se, precisamente, a partir da actividade de Nicolás Antonio, o conhecido autor de Biblioteca hispana, o qual, "antes de permanecer em Roma de 1654 a 1678", havia concebido «el proyecto de una crítica general de todos los falsos cronicones», do qual foi publicado, no século XVIII, a inacaba Censura de historias fabulosas (Jesús Villanueva López, Politica y discurso histórico en la España del siglo XVII. Las polémicas sobre los origenes medievales de la Cataluña. Alicante: Publicaciones de la Universidad de Alicante, 2004, p. 197).

38 «Por huir al fastidio, y acomodarme a la suave novedad, omito las citaciones. Los sabios, bien sabrán conocer lo que es ageno, ò mio; los legos, no importa que no lo adviertan» (El Fenis de Africa, Agustino Aurelio, obispo hypponense [...]. Lisboa: por Pablo Craesbeeck, 1649, 2a parte, prefácio; Benjamin Nicolaas Teesma, Don Francisco Manuel de Melo, p. 114).

39 Tácito, p. 44.

40 Joan Estruch, «Las fuentes de Guerra de Cataluña, de Francisco Manuel de Melo», Criticón: revista de la R. C. P. 439 del C. N. R. S. Toulouse: Université de Toulouse - Le Mirail, vol. 44, (1988), pp. 7-24; vide também as suas anotaçôes à ediçáo de História de los movimientos, onde se reflecte a sua tese de doutoramento, segundo presumimos, fundamental nesta questão, dado que procedeu a uma edição crítica da Guerra de Cataluña. Só tivemos acesso ao resumo da dissertação, que consultámos na BNP (Joan Estruch Tobella, Vida y obra de Francisco Manuel de Melo. Barcelona: Universitat, 1985).

${ }^{41}$ Para fontes francesas do naufrágio de 1627, vide Jean-Yves Blot e Patrick Lizé, eds., Le naufrage des portugais sur les côtes de Saint-Jean-de-Luz et d'Arcachon (1627). Relations de Dom Manuel de Meneses et Dom Francisco Manuel de Melo (Epanáfora Trágica) traduites par Georges Boisvert et autres documents. Paris: Éditions Chandeigne, 2000). A narrativa de Melo, "Même si quelques erreurs dues à une memoire défaillante se glissent dans sa relation, celle-ci est littérairement la plus achevé» (p. 11). Documentos de natureza militar publicados por Edgar Prestage (D. Francisco Manuel de Mello, p. 434), indicam o naufrágio como ocorrido a 14 de Janeiro de 1627. A Epanáfora II está datada, através da carta prologal, de 5 de Fevereiro de 1657. O naufrágio ocorreu entre 12 e 13 de Janeiro de 1627. A madrugada de 14 estava já muito bonançosa, como explicita D. Manuel de Meneses (Epanaphoras, p. 599).

${ }^{42}$ Francisco Manuel de Melo, D. Teodósio II. Segundo o códice 51-III-30 da Biblioteca da Ajuda. Tradução e prefácio de Augusto Casimiro. Porto: Livraria Civilização- Editora, 1944, p. 41). Facilidades concedidas que só poderiam ser satisfeitas através de interposta pessoa ou eventual saída da prisão sob palavra, numa espécie de menagem. Também Filipe IV, ao ordenar a história da monarquia a Francisco Ramos del Manzano, ou Olivares em relação a Malvezzi, entenderam, na sequência de outros exemplos, "a autoridade que os papéis de Estado" emprestavam aos escritos hitóricos. O conde-duque «deixou saquear o seu escritório» a Malvezzi e o monarca permitiu a Ramos «rebuscar a su antojo en los incomparables archivos reales de Simancas» (R. A. Stradling, Felipe IV y el gobierno de España 1621-1665. Madrid: Cátedra, 1989, p. 438). 
para além da bibliografia ${ }^{44}$. O que lhe agradava, no entanto, era o testemunho presencial dos acontecimentos, a sua observação e reflexão, «lendo, conferindo, praticando» ${ }^{45}$.

Com efeito, para além da bibliografia e das fontes que muitas vezes corriam manus$\operatorname{critas}^{46}$, lançou mão, como tanto gosta de lembrar quando historia acontecimentos coevos, em muitos dos quais tomou parte, da experiência da vida e do que soube sentir, ver, ouvir e guardar numa tenaz e pronta memória ${ }^{47}$.

«Escrevo có toda a inteireza, o que vi muytas vezes, \& quasi me passou pellas mãos», esclarece ao redigir a Epanáfora Bélica ${ }^{48}$. Dói-se por ser praticamente a última testemunha do relato da tragédia marítima de $1627^{49}$, embora a Epanáfora Trágica pareça conter inicialmente, para além da utilização bibliográfica, esboços de outros trabalhos ou, pelo menos, explanaçóes mais extensas de enquadramento ${ }^{50}$, constituindo as "digressóes» nos seus trabalhos historiográficos, como ajuíza, «verdadeiros tropos históricos e não proluxos pleonasmos, pelo que nunca costumo desculpar-me deles» ${ }^{51}$.

${ }^{43}$ Algumas delas solicitadas por cartas e ofícios (D. Teodósio, p. 41; Edgar Prestage, Dom Francisco Manuel de Mello, p. 606). Nas notas do presente trabalho vão indicadas diversas fontes referidas por D. Francisco Manuel.

${ }^{44}$ Uma ordenação alfabética dos autores citados em algumas das suas obras encontra-se em José Manuel Teixeira dos Prazeres, D. Francisco Manuel de Melo. Subsidios para a história das suas ideias. Coimbra: Secção de Textos, 1967, diss de lic., policopiada, p. 368 s. Para D. Teodósio indica 22 autores.

${ }^{45}$ D. Teodósio, p. 40.

${ }^{46}$ Historia de los movimientos, pp. 308-309. Muitos dos "papéis» catalãos foram impressos em Portugal em 1641 e 1642 (Estruch). Um deles, em Lisboa e Barcelona, o de Gaspar Sala, Epitome de los principios y progresos de las guerras de Cataluña en los años de 1640 y 1641 y señalada victoria de Momjuyque. Barcelona / Lisboa: Pedro Lacavalleria, Antonio Alvarez, 1641.

${ }^{47} \mathrm{O}$ presente «decreta sobre o passado em vista do futuro e nisso faz valer a memória sobre a investigação empírica e sobre qualquer pretensáo de antiquário" (António Horta Fernandes, Entre a História e a Vida. A teoria da História em Ortega y Gasset. Lisboa: Cosmos, 2006, p. 83).

${ }^{48}$ Epanaphoras, p. 359. Em 1639, ao chegar a Flandres, a seguir à batalha do Canal, o governador, que no momento era o cardeal infante D. Fernando, irmão de Filipe IV, ordenou a D. Francisco que fizesse uma relação do sucedido. O exemplar da primeira redacção que lhe foi entregue seguiu depois para a corte de Madrid, acabando o secretário de Estado e Guerra do infante, D. Miguel de Salamanca, que antes havia desempenhado em Flandres o lugar de Vedor Geral, por lhe pedir o original, em substituição da primeira via. Ao chegar a Aragáo, em 1640, e antes de começar a guerra de Catalunha, voltou a refazer de início o relato do "conflito do Canal de Inglaterra». A prisão a que pouco depois foi submetido, agora apenas por ser português, como ajuíza, deu origem à confiscação de todos os seus papéis, os quais seriam, na sua informação, "os mais e melhores, que até então havia escrito». Mais tarde escreverá a terceira versão da Epanaphora Bélica, que é a que se encontra publicada (Epanaphoras, pp. 353-354). Cf. infra, n. 75.

${ }^{49}$ Epanaphoras, p. 157.

${ }^{50}$ Como a evoluçáo da organização da armada de Portugal no tempo filipino; as relaçôes da monarquia hispânica com a Inglaterra; as descriçôes da Galiza ou de Biscaia ou a indicaçâo dos aventureiros embarcados. A relação abre, de resto, com a apresentação de alguma bibliografia. Em o Tácito, pp. 46-48, há também uma digressão sobre o intrincado problema dos moradores da casa real, que bem poderia constituir o esboço de trabalho independente. Sobre os graus dos «moradores» da corte, vide, por exemplo, Sérgio da Cunha Soares, "Nobreza e arquétipo fidalgo - A propósito de um livro de matrículas de filhamentos (1641-1724)», Revista de Hitsória das Ideias». Coimbra: Faculdade de Letras, vol. XIX, (1998), pp. 403-455; António de Oliveira, coord., Nova História de Portugal, vol. VI (Da Contra-Reforma à Restauração), cap. sobre "As hierarquias da diferença», no prelo. Sobre a casa real ao tempo de Filipe III, vide, Félix Labrador Arroyo, "La casa real portuguesa (15981621)", in José Martínez Millán e Maria Antonietta Viscelia, dirs, La monarquía de Felipe III: los reinos. Madrid: Fundación MAPFRE/ Instituto de Cultura, 2008, pp. 809-859.

${ }^{51}$ Epanaphoras, p. 312. 
É a supremacia do ver e ouvir que leva a optar por Francisco Alcoforado em vez de João de Barros, ao aceitar a narrativa daquele como coeva dos companheiros do redescobridor ${ }^{52}$, e a preferir a história do passado não muito longínquo, um benefício em favor da verdade do seu D. Teodósio ${ }^{53}$. Não utilizando muito as «antiguidades», que parece não gostar numa das suas dimensóes ${ }^{54}$, separando-se, assim, da historiografia renascentista, e conhecendo moderadamente o perigo dos textos sobre o passado antigo, ao mesmo tempo que náo tinha disponibilidade física para documentalmente investigar o passado que não viveu, o padrão de verdade ficava assinalado pela experiência. A verdade da Guerra de Cataluña resulta, como presumia, de nela ter tomado parte, embora não seja bem assim, como está provado.

Mas para além da experiência dos campos e dos mares da guerra, existia um outro espaço de aprendizagem e de recolha privilegiada de informaçóes, que era a corte, como Cabrera de Córdoba recordou e a que especificamente também recorreu D. Francisco Manuel. Espaço mais de ouvir do que dizer, onde se tornava preciso um grande espírito crítico para saber destrinçar o verdadeiro dos boatos, criados no próprio círculo do mentidero cortesão de Madrid e, certamente, de Lisboa ${ }^{55}$. Com efeito, foram as necessidades práticas das suas

\footnotetext{
${ }^{52} \mathrm{Na}$ descrição da ilha da Madeira, datada de 1654 no texto editado, há erros de topografia, como apontou Álvaro Rodrigues de Azevedo, ao anotar Gaspar Frutuoso, As Saudades da Terra: História das Ilhas do Porto Santo, Madeira, Desertas e Selvagens. Funchal: Typ. Funchalense, 1873, na indicação de Edgar Prestage, D. Francisco Manuel de Mello, p. 298; outras apreciaçóes negativas in António Gonçalves Rodrigues, D. Francisco Manuel de Mello e o descobrimento da Madeira (A lenda de Machim). Lisboa: Eds. Bíblion, 1935. D. Francisco Manuel esteve quase um mês na ilha, em 1655, quando em viagem para o Brasil do desterro (Edgar Prestage, $D$. Francisco Manuel de Mello, p. 276). Qual a influência na descrição da natureza, que poderia ter retocado? O que se refere à saudade é da responsabilidade de D. Francisco: "quero eu agora tomar sobre mi esta notícia». O arquipélago da Madeira, conhecido já no século XIV, recebeu os primeiros colonos entre 1419 e 1426 (Vitorino Magalhães Godinho, A expansão quatrocentista portuguesa. Lisboa: D. Quixote, 2008, 3a ed., pp. 301 e s.). Vide, a propósito da Epanáfora Amorosa, Manuel Ferro, «Arquipélago de sonho, miragem do paraíso: a Madeira na épica portuguesa do barroco e neoclassicismo», Biblos. Coimbra: Faculdade de Letras, vol. VI (2a série), 2008, pp. 271 s. e o estudo de Maria do Céu Fraga apresentado neste colóquio e, adiante, n. 63 e 64.

53 «No se puede negar, que mientras vivieron [os historiadores] mas cercanos a la edad, en que sucedieron las cosas que escrivieron, tanto son mas dignos de fe, que los que historiarô muchos ańos despues, porque se pone duda en su verdad; donde se concluy, que quien escrieve lo que sucedio en su edad, merece mas credito" (Luis Cabrera de Córdoba, De Historia para entenderla y escrivirla. Madrid: por Luis Sanchez, 1611, fl. 37v.).

${ }^{54} \mathrm{O}$ prestígio das «antiguidades», numa das suas feiçốes, era então muito grande, opondo-se-lhe Melo, pela voz de Lípsio (Hospital das Letras, p. 262). Mas na apreciação do Nuno Álvares Pereira de Méndez Silva, não deixou de anotar: «Estimando, como é justo, o copioso aparato de antiguidades que V. M. neles nos descobre» (Cartas, p. 86). E a propósito da descrição de Galiza não deixa de qualificar Gaspar Barreiros, censor de Beroso, como "eminentissimo antiquário" (Epanaphoras, p. 217). Definição de Antiquários e enumeração dos objectos que lhe correspondem em Luis Cabrera de Córdoba, De Historia para entenderla y escrivirla, p. 63; Maria Teresa Amado, A Lingua do Ver, p. 236, n. 19. Sobre censuras a Beroso, ou melhor, a Annius ou Annio de Viterbo (Giovanni Nanni), vide infra, n. 209.

55 Como já foi observado, a propósito da Carta de Guia de Casados, soube transformar a «arte exímia de cerzir mil experiências próprias» «numa carta missiva escrita com todas as regras postuladas pela epistolografia, e dirigida a noivo amigo» (Maria Lucília Gonçalves e José Adriano de Carvalho, História Crítica da Literatura Portuguesa [Maneirismo e Barroco], Direcção de Carlos Reis. Lisboa: Editorial Verbo, 2001, p. 169). Sintetizei a expressão citada entre aspas. Método que aplica, com a sua especificidade, à História que professou, transformando os fios da documentação numa obra de autor e não apenas numa figuração de cerzidor, como em certo momento achacava a Virgílio Malvezzi (1595-1654), colocado por D. Francisco Manuel entre os que «buscam os que digam por eles o que por si não sabem fazer», embora também dele fosse devedor e o qualificase, noutro local, como «autor ilustre mas animoso». Cf., adiante, n. 254.
} 
pretensóes na corte de Madrid, ou simplesmente a ociosidade, onde esteve umas dez vezes, segundo declara, que lhe permitiram alcançar, através da conversação, da prática e também do estudo, «os estilos, preeminencias, \& privilegios» dos conselhos de Estado e da Guerra de Castela, fazendo-os preceder de uma indicação sumária dos 14 outros conselhos existentes. Aula Política \& Curia Militar (1653) ${ }^{56}$ redigida, "por mandado de um grande rogo», com o intuito de ser útil à organização dos conselhos da corte de Lisboa ${ }^{57}$, dando mais uma vez testemunho de se colocar acima das fronteiras geográficas: «eu não sou natural senão da verdade», como fez um dia dizer à boa moeda de ouro denominada português ${ }^{58}$. Por sinal, escolheu por pseudónimo, para a edição francesa de Guerra de Cataluña, de 1654, «Le Sieur Cosmophile» $^{59}$.

4.

Para além do ponto comum da contemporaneidade, com as conhecidas excepçóes ${ }^{60}$, as obras históricas principais redigidas por D. Francisco Manuel, entre as quais se encontram as relaçóes que denominou Epanáforas ${ }^{61}$, apresentam a guerra como tela de fundo, como se

${ }^{56}$ Aula Politica \& Curia militar [...]. Lisboa: Officina de Mathias Pereira da Sylva, \& Joam Antunes Pedrozo, 1720, editada, com outras obras. Para «os fiadores da verdade do meu discurso», p. 3.

${ }^{57}$ Aula Politica, p. 2 e $\$$ CLIV.

${ }^{58}$ Escritório Avarento, p. 18. A mesma ideia encontra-se expressa em outros locais (Cartas, p. 100).

${ }^{59}$ Existe um exemplar catalogado na Biblioteca Nacional de Holanda (KB catalogus Boeken en Tijdschriften). Segundo Teensma, foi o próprio D. Francisco que fez a tradução (Benjamin Nicolaas Teensma, «De France vertaling von de Guerra de Cataluña de Don Francisco Manuel de Melo, Roemond, 1654", in Forum Literarum. Miscelânea de Estudos Literários, linguísticos e históricos oferecida a J. J. von den Besselaar. Amesterdam \& Maarsen: APA - Holanda University Press, 1984, pp. 133-150). Reproduzimos a informação do artigo, que se encontra catalogado na internet, dada por Antonio Bernat Vistarini, D. Francisco Manuel de Melo, p. 128, n. 300. Colomès havia antes indicado o exemplar de Roermond, que diz tratar-se de uma versão incompleta de Guerra de Cataluña, e localizado um outro na Biblioteca de Catalunha, Barcelona, afirmando, quanto ao pseudónimo, tratar-se de «Cosmopolite» (Jean Colomès, Le dialogue «Hospital das Letras» de D. Francisco Manuel de Melo. Texte établi d'après l'édition princeps. Paris: Centro Cultural Português da Fundação Calouste Gulbenkian, 1970, p. 278, n. 356). Da "Biblioteca de Catalunya», como resposta a um nosso pedido sobre a localizaçáo da obra, recebemos gentilmente uma fotografia digital do verbete ainda manuscrito da catalogaçáo, onde o autor tambem se encontra literalmente transcrito como «Cosmophile».

${ }^{60} \mathrm{Da}$ contemporaneidade das suas obras exceptuam-se, como é óbvio, a biografia que compôs de S. Francisco (a de Santo Agostinho parte da história, mas não constitui propriamente o que se pode chamar história), assim como a matéria da Epanáfora Amorosa e uma parte do que redigiu sobre D. Teodósio ou compôs a propósito das genealogias dos reis. Quanto a El Fenis, esclareceu o autor: "Aviso, no se venga a moralmente buscar a mis escritos el hilo historial de sus acciones; porque mi intención, no es otra, que discernir, por algunas; sacando dellas nuestra dotrina, y su alabança». E ainda: «No ha sido mi proposito historiar la vida de San Agustin» (El Fenis de Africa, parte primeira, "Carta a los lectores»).

${ }^{61}$ Epanáfora, que significa relação, pode ser considerada um «subgénero historiográfico» (Joan Estruch Tobella, Entre la historia y la novela: la "Epanafora Amorosa" de Francisco Manuel de Melo. Nápoles: Societá Editrice Intercontinentale Gallo, 1993, pp. 1-2, sep. de "Annali dell' Istituto Universitario Orientale» Sezione Romanza XXXV, 1; José G. Herculano de Carvalho, "Três notas filológicas a D. Francisco Manuel de Melo", Revista Portuguesa de Filologia. Coimbra: Faculdade de Letras vol. XIX, (1991), pp. 242-247. O próprio D. Francisco Manuel explicita o que entende por epanáfora em Cartas Familiares, p. 491, e no Hospital das Letras, p. 
estivesse seguindo "o cânone de Tucídedes» ${ }^{62}$. O tema amoroso foi considerado nas suas consequências públicas numa das relaçóes sobre história de Portugal, dando-lhe um tom «entre a novela e a história», na designação de Joan Estruch ${ }^{63}$, ou de simples história, «no mesmo plano das restantes Epanáforas», segundo Herculano de Carvalho ${ }^{64}$, mas é ainda uma guerra, um rapto de mulher casada, «estimada como hũa maravilha de muytas maravilhas», que lhe dá origem e sequência através de raptos de corsários, vivências de cativos e a força heróica contra o temor do mar ainda não experimentado e da natureza não explorada.

As obras de índole histórica elaboradas no século XVII, pertencem a um mundo conturbado, a um século turbulento, como D. Francisco Manuel o qualifica ao dedicar a Historia de los movimientos, separación y guerra de Cataluña ao Papa Inocêncio $\mathrm{X}^{65}$. Século

254. Os termos de uma relação, segundo o própro D. Francisco, costumavam estar «demarcados com pouca largueza», os quais estendeu, por exemplo, na Epanáfora Triunfante, tendo o cuidado de acrescentar a sentença, atribuindo-a à Antiguidade: «os escritores não só pintão para a vida do tẽpo, mas para a universalidade dos homens» (Epanaphoras, pp. 481-482). Estava muito divulgada a comunicaçáo dos eventos coevos através de cartas, avisos, relaçóes ou gazetas, as quais podiam assumir um mais abstracto jogo crítico do espírito, como procedeu Boccalino, Trajano (1556-1613), nas Raggualli di Parnaso, personalidade acolhida como «símbolo de inconformismo" por D. Francisco Manuel, segundo Giacinto Manuppela (D. Francisco Manuel de Melo, $A$ Visita das Fontes. Apólogo dialogal terceiro. Edição fac-similada e leitura do autógrafo, 1657, introdução e comentário por Giacinto Manuppella. Coimbra: por Ordem da Univrsidade, 1962, pp. 417-418).

${ }^{62} \mathrm{Na}$ indicação de Fernández Albaladejo, citando, para além de D. Kelley, Arnaldo Momigliano, La Historiografía griega. Barcelona: Crítica, 1984, cap. 2 e 8. Para Juan Páez de Castro, na expressão de Fernández Albaladejo, "La contemporaneidad era después de todo el habitat de la historia proprie nominata y la guerra su paisaje más frecuente» (Pablo Fernández Albaladejo, «'Materia' de Espańa y 'edificio’ de historiografía. Algunas consideraciones sobre la década de 1540», p. 63). O acentuar da contemporaneidade em D. Francisco Manuel, já se encontra indicada, pelo menos, em Hernâni Cidade, Liçóes de cultura e literatura portuguesas. Coimbra: Coimbra Editora, 1975, 1º vol., 6a ediçấo, p. 417.

${ }^{63}$ Joan Estruch Tobella, Entre la historia y la novela, p. 105. Por volta de 1654, D. Francisco Manuel decidiu pôr em execuçáo um antigo projecto de tratar um feito da história de Portugal que tivesse "procedido, ou ilustrado, de afectos amorosos", sugerido pela leitura de relaçôes elaboradas pelo cardeal Guido Bentivoglio, segundo declara (Epanaphoras, p. 275), mas com outras possíveis influências, como as de Agostino Mascardi e Bartolomé Leonardo Argensola, na proposta de Estruch (ibidem, pp. 102-103), segundo uma linha historiográfica denominada por Fueter de "historiografia galante ou novelesca» (Fueter, Ed., Historia de la historiografía, pp. 364 s., indicada já por Estruch). As Relaçóes citadas do cardeal Guido Bentivoglio (1577-1644) haviam sido traduzidas para castelhano em 1638 e uma delas trata, efectivamente, «da fuga de França do príncipe de Condé para livrar a esposa do assédio de Henrique IV» (Joan Estruch, Entre la historia y la novela, p. 103). O conhecimento das suas obras por parte de Francisco Manuel de Melo data antes da morte de Bentivoglio, dado que teve intenção de lhe oferecer, se tivesse sido Papa, a Guerra de Cataluña (Hospital das Letras, p. 195). Na biblioteca real portuguesa existia um exemplar das Guerras de Flandres e outro de Relações, $4^{\circ}$, pergaminho, sendo este avaliado em 200 réis no inventário post-mortem de D. Pedro II.

${ }^{64}$ José G. Herculano de Carvalho, Três notas filológicas a D. Francisco Manuel de Melo, p. 247. Como simples novela a considera Gonçalves Rodrigues, designando-a como «um dos poucos exemplos portugueses no século XVII dum género popularíssimo noutros países (António Gonçalves Rodrigues, D. Francisco Manuel de Mello, p. 45). Já em 1579, no entanto, a narrativa de Alcoforado havia sido aproveitada, como fonte histórica, por Jerónimo Dias Leite, Descobrimento da Ilha da Madeira e discurso da vida e feitos dos capitães da dita ilha. Tratado composto em 1579 e agora publicado com introdução e notas de João Franco Machado. Coimbra: Faculdade de Letras /Instituto de Estudos Históricos Dr. António de Vasconcelos, 1947.

${ }^{65}$ O Papa Inocêncio X governou a Igreja de 1644 a 1655. A dedicatória está datada de 10 de Outubro de 1645. Utilizámos a edição de Joan Estruch Tobella, Madrid, Clásicos Castalia, 1996, onde a dedicatória ocupa as pp. 62-63. O título desta edição é o que reproduzimos no texto. 
que se pode estender, entre nós, de 1580 a cerca de 1680, data tópica de muitas viragens, anunciadoras de outros tempos, incluindo para a historiografia em geral, sendo, por exemplo, de 1681 o De re diplomatica de Jean Mabillon $(1632-1707)^{66}$, de 1683 o manuscrito do Sigalion de Pedro Fernández del Pulgar ${ }^{67}$ e de muito antes, para Espanha, a actividade crítica de Nicolás Antonio, como já referimos ${ }^{68}$. Tempo já de «saber duvidar» ${ }^{69}$ e de um novo discurso historiográfico com o alvorecer do iluminismo, tempo novo anunciado já em aspectos da produção histórica de D. Francisco Manuel ${ }^{70}$.

O século turbulento foi, na verdade, um período de profundas perturbaçóes, as quais foram e têm sido expressas por diversos modos ${ }^{71}$, salvaguardando-se, no tecido envolvente, as tramas espaço-temporais com desenhos diferenciadores do sentido aparente. De qualquer modo, no que concerne ao «agitado e alvorotado", ao "turvo e ao confuso", ao "desordenado», sinonímias que os dicionários indicam para turbulento, a guerra foi uma constante, para além dos movimentos sociais das turbas.

A Espanha, com efeito, teve de travar pelo menos 76 guerras ao longo do século $\mathrm{XVII}^{72}$. Portugal, por sua vez, esteve praticamente em guerra entre 1580 e 1668, tendo-a sofrido em todos os continentes ${ }^{73}$. Pela altura da derrota dos espanhóis nas Dunas ${ }^{74}$, em 1639, onde

${ }^{66}$ De re diplomatica [...]. Lutetiae Parisiorum: sumtibus L. Billaine, 1681.

${ }^{67}$ Pedro Fernández del Pulgar, Sigalión o chiton de los chronicones fabulosos, y supuestos, que se han publicado en España, desde el año 1594 con titutlo de Historiadores Antigos. Manifestase que son ficciones de Autores modernos, y en especial el Chronicon de Auberto Hispalense. Fantasia en un Dialogo Jocoserio, dividido en dos partes, ante Sigalión Critico severo de Atenas. Ańo 1683. Transcrição do manuscrito existente na Real Academia de la Historia, de Madrid, por MariaTeresa Amado, A Língua do Ver, vol. II, anexo II. Apreciação nas pp. 401 e s. do I volume.

${ }^{68}$ Jesús Villanueva López, Politica y discurso histórico en la España del siglo XVII, pp. 195 s. Sobre a obra do Pe Jacinto Segura (1668-1751), entre outros inovadores historiográficos em Espanha, vide Henrique García Hernán, "Construcción de las Historias de España en los siglos XVII y XVIII», in Ricardo García Cárcel, coord., La construcción de las Historias de España. Madrid: Fundación Carolina. Centro de Estudios Hispánicos y Iberoamericanos / Marcial Pons, 2004, pp. 162 s. Cf. supra, n. 37.

${ }^{69}$ Guy Bourdé e Hervé Martin, As Escolas Históricas. Lisboa: Publicaçōes Europa-América, 2003, p. 63; Paul Hazard, Crise da Consciência europeia. Lisboa: Cosmos, 1971, p. 37, para o pirronismo histórico.

${ }^{70}$ Vide, a propósito da nova época historiográfica em Portugal no século seguinte, Isabel Ferreira da Mota, $A$ Academia Real da História. Os intelectuais, poder cultural e poder monárquico no século XVIII. Coimbra: Minerva, 2003.

${ }^{71}$ Idade de ferro e de ouro, consoante os modos de aquilatar as vivências e as culturas. Tempo de guerras permanentes em procura de paz vantajosa, de conjunturas de peste, de modificaçáo do clima a caminho de longa duração, época de crise, de contradiçóes, de claros e escuros, de desengano, de declinação, para além de outras apreciações contidas em bibliografia numerosa. D. Francisco Manuel alude à melancolia, desengano, declinação (Tácito, p. 53), «idade tanto de ouro como de ferro" (Tácito, p. 65) ou ao tempo «em que padeciam quase todos os príncipes da Europa intestinos e perigosos movimentos» (Tácito, p. 101). Para o desengano como tema moral, vide José Adriano de Carvalho, Aspectos do desengano e da aceitação da vida em D. Francisco Manuel de Melo. Lisboa: Ediçốes Brotéria, 1964. Sep. de «Brotéria», vol. 78 (1964).

${ }^{72}$ De 1600 a 1701: 41 anos de confronto com a França, 34 com a Holanda, 14 com a Inglaterra, etc. (Antonio Simón Tarrés, «La politica exterior», in Domínguez Ortiz, Antonio, dir., Historia de España, tomo VI. Madrid: Planeta, 1988, p. 339.

${ }^{73}$ Vide enumeração em Armando da Silva Saturnino Monteiro, Batalhas e combates da marinha portuguesa vol. VI 1626-1668. Lisboa: Livraria Sá da Costa Editora, 1995, p. 420.

${ }^{74}$ Com mais propriedade, «batalla del fondeadero de los Downes" (Víctor San Juan, La batalla naval de las Dunas. La Holanda comercial contra la España del Siglo de Oro. Madrid: Sílex, 2007, p. 10). 
navios de Portugal e militares como D. Francisco Manuel estiveram presentes ${ }^{75}$, Quevedo observava que «Primero nos faltarán lagrimas que causas de llorar» ${ }^{76}$. Não tinham ainda chegado os finais de 1640 e decénios seguintes, dentro e fora da península - Catalunha, Portugal, Andaluzia, Nápoles, Sicília ${ }^{77}$ - e o reconhecimento, em 1648, da independência das Províncias Unidas, terminando com uma guerra iniciada oitenta anos antes.

D. Francisco Manuel de Melo nasceu e viveu, assim, em pleno tempo bélico, o qual não podia deixar de influenciar a sua vida e obra. Vida de batalha, na guerra dos outros e com a que pessoalmente lhe moviam, para além da luta interior que travou consigo mesmo $^{78}$. Nasceu, com efeito, na véspera de um período de tréguas no continente de

${ }^{75}$ Francisco Manuel de Melo, Epanaphoras, pp. 349-478, correspondente à epanáfora Conflito do Canal de Inglaterra entre as armas espanholas e olandezas. Ano 1639. Epanapfora Belica. Quarta. D. Francisco Manuel de Melo justifica a sua inclusão num volume sobre história portuguesa precisamente porque «grande parte das armas, ocupadas naquelle congresso, forão regidas por nossos Lusitanos. Forças, navios, \& dispendios de Portugal, nos fazião proprio seu emprego» (Epanaphoras, p. 350). A narrativa de Melo, com muitas preocupaçóes autobiográficas, deve ser considerada no conspecto geral da luta de Espanha com os Países Baixos. Vide, a propósito, Alcalá-Zamora y José Queipo de Llano, España, Flandes y el mar del Norte (1618-1639). La última ofensiva europea de los Austrias madrileños. Barcelona: Planeta, 1975; Robert A. Stradling, La armada de Flandes. Política naval española y guerra europea 1568-1668. Madrid: Cátedra, 1992, pp. 146 s; María del Carmen Saavedra Vázquez, Galicia en el camino de Flandes, pp. 179 s.; Víctor San Juan, La batalla naval de las Dunas; René Vermeir, En estado de guerra. Felipe IV y Flandes 1629-1648. Traducción: Lieve Behiels. Córdoba: Universidad de Córdoba, 2006. Não cita o autor das Epanáforas e considera, na p. 161, que «A pesar de la casi destrucción de la flota de Oquendo, se conseguió en parte el objetivo esencial de la operación». Considere-se, no entanto, que «Olivares procuró, con el mismo afán con que se aplicó a la imposible reconstrucción de la armada, que no se divulgase la transcendencia de lo ocorrido, cosa que casi conseguiría, silenciando los ecos de la batalla de las Dunas hasta nuestros mismos días" (José Alcalá-Zamora, Razón y crisis de la politica exterior de España en el reinado de Felipe IV. Madrid: Fundación Universitaria Espańola, 1977, pp. 26 s.). A ser assim, fica explicado porque teve Melo de entregar a cópia ou borrão da primeira versão dos acontecimentos, ordenada por D. Miguel de Salamanca, tendo sido igualmente confiscada, com outros escritos seus, a segunda composiçáo ao tempo em que foi preso por motivo do movimento do primeiro de Dezembro, como anteriormente repetimos. Cf. supra, n. 48.

${ }^{76}$ Citado em Víctor San Juan, La batalla naval de las Dunas, p. 9.

${ }^{77}$ Para além dos acontecimentos em Portugal, pode ver-se: Xavier Gil Pujol, «Felipe IV y la crisis de la monarquía Hispánica. Pérdida de hegemonía y conservación (1643-1665)», in Alfredo Floristán, coord., Historia de España en la Edad Moderna. Barcelona: Ariel, 2004, pp. 513-538; J. H. Elliott, «Revueltas en la monarquía espańola», in J. H. Elliott, Roland Mousnier e outros, Revoluciones y rebeliones de la Europa Moderna. Madrid: Alianza, 1978, pp. 123144; J. H. Elliott, La rebelión de los catalanes. Un Estudio sobre la decadencia de España (1598-1640). Madrid: Siglo XXI, 1986, 3a ed. espanhola; Rosario Villari, La rivolta antiespagnola a Napoli. Le origini 1585-1647. Roma-Bari: Laterza, 1976; Pier Luigi Rovito, La rivolta dei notable. Ordinamenti municipali e dialectica dei ceti in Calabria Cita 1647-1650. Napoli: Jovane Editore, 1998; Luis Antonio Ribot García, La revuelta antiespagnola de Mesina. Causas y antecedentes (1591-1674).Valladolid: Universidad de Valladolid, 1982: idem, La Monarquía de España y la Guerra de Mesina (1674-1678). Madrid: Actas, 2002; idem, «Las revueltas Sicilianas de 1647-1648», in Antoni Simón i Tarrés, ed., 1640. La Monarquía Hispánica en crisis. Barcelona: Crítica, 1992, pp. 183-199; Antonio Domínguez Ortiz, Alteraciones andaluzas. Madrid. Narcea, 1973; idem, «La Conspiración del Duque de Medina Sidonia y el Marqués de Ayamonte», in idem, Crisis y decadencia de la España de los Austrias. Barcelona. Ariel, 1984, pp. 115-153; Luis Salas Almela, Medina Sidonia: El poder de la aristocracía 1580-1640. Madrid: Marcial Pons, 2008, pp. 309 s.

${ }^{78}$ Maria Lucília Gonçalves Pires, «O tema da «guerra interior» nas obras métricas de D. Francisco Manuel de Melo", in idem, Xadrez de palavras. Estudos de literatura barroca. Lisboa: Cosmos, 1996, pp. 53-74; Sara Augusto, "A Guerra Interior: ficção narrativa alegórica», in Estudos para Maria Idalina Rodrigues, Maria Lucília Pires, Maria Vitalina Leal de Matos. Lisboa: Departamento de Línguas Românicas / Faculdade de Letras da Universidade de Lisboa, 2007, pp. 821-822. 
Portugal com os holandeses, mas não no ultramar, iniciado em $1609^{79}$, e de paz com a Inglaterra, a qual vinha de 1604. Mas aos 17 anos, em 1625, ao alistar-se pela primeira vez como soldado numa companhia de aventureiros, a Espanha estava de novo em guerra muito activa na persecução de uma política de prestígio, de reputaçáo. No ano seguinte serviu numa das galeras espanholas das seis que guardavam o Tejo ${ }^{80}$ e em Setembro do mesmo ano, acompanhado de três criados, aconchego medieval que já tivera no primeiro alistamento, embarca também numa companhia de aventureiros da armada, que bem se sabe que são voluntários ${ }^{81}$, de que era general D. Manuel de Meneses, seu mestre também em matérias para além das armas ${ }^{82}$.

Há quem diga que foi para afastar as mágoas de amor que se alistou em 1625, sob o comando do capitão Diogo de Mendonça Furtado ${ }^{83}$. Náo creio que tivesse sido bem assim, se bem que uma novela que teria escrito na idade crítica dos 18 anos, hoje desconhecida ${ }^{84}$, possa alicerçar semelhante hipótese, não obstante o seu racionalismo, sendo pouco atreito às grandes efusôes sentimentais, pelo menos quando adulto ${ }^{85}$. De qualquer modo, D. Francisco Manuel

${ }^{79}$ Juan E. Gelabertt, «El artículo IV de la Tregua de los Doce Años (1607-1609), in Manuel-Reyes García Furtado, Domingo L. González Lopo e Enrique Martínez Rodríguez, eds., El mar en los siglos modernos, vol. II. Santiago de Compostela: Xunta de Galicia, 2009, pp. 187- 208.

${ }^{80}$ Edgar Prestage, D. Francisco Manuel de Mello, p. 432. D. Francisco tinha então 18 anos (ibidem, p. 434). Para este começo do currículo militar de D. Francisco, seguimos a documentação publicada por Edgar Prestage, D. Francisco Manuel de Mello, pp. 431-434, docs. $\mathrm{n}^{\mathrm{os}}$ 4-7. Continuação curricular em D. Francisco Manuel de Melo, Política militar, introdução de Pedro de Brito, pp. 16 s.; Paulo Silva Pereira, D. Francisco Manuel de Melo e o modelo do "cortesäo prudente e discreto" na cultura barroca peninsular. Coimbra: [s. n.], 2007, pp. 313 s., diss. de doutoramento. De 1626 até Outubro de 1638, serviu na «armada do Oceano e Coroa de Portugal» (AGS, GA, m. 1325, doc. 335). Vide infra, n. 339.

${ }^{81}$ Sinonímia em D. Francisco Manuel de Melo, Historia de los movimientos, p. 255. Mais adiante, na p. 273, equipara voluntário a soldado particular. $\mathrm{O}$ anotador da edição apresenta-o como "o voluntário que pagava os seus gastos», aduzindo também um texto de sentido idêntico de Diego Hurtado de Mendoza. No segundo embarque de 1626, em princípio de Setembro, na armada que tinha por general D. Manuel de Meneses, D. Francisco Manuel recebeu 2400 réis de soldo, mas os três criados que levou não recebiam soldo (Edgar Prestage, D. Francisco Manuel de Mello, p. 434). Sobre estes vestígios medievais, embora a nobreza constituísse agora «o nervo da infantaria espanhola», vide René Quatrefages, Los tercio españoles (1567-77). Madrid: Fundación Universitaria Espańola, 1979, p. 296.

${ }^{82}$ Francisco Manuel de Melo, Epanaphoras, p. 268. Sobre a biografia de D. Manuel de Meneses, vide também Diogo Barbosa Machado, Bibliotheca Lusitana, tomo III. Coimbra: Atlândida Editora, 1966, pp. 310-312. Cf. infra, n. 89 e 164 .

${ }^{83}$ Fernando Campos, «D. Francisco Manuel de Melo: opções para o romance O Prisioneiro da Torre Velha», Memórias da Academia das Ciências de Lisboa, Classe de Letras, tomo XXXVI, 2004-2005, p. 128. A enamorada era a prima Branca Vilhena da Silveira (Teófilo Braga, História da Literatura Portuguesa III Os Seiscentistas. Lisboa: Publicaçóes Europa-América, pp. 134 s.), que casou com o tio D. Gregório, $3^{\circ}$ conde de Vila Nova de Portimáo, e que foi a sua primeira mulher, na interpretação de Fernando Campos. D. Branca morre em 30 de Abril de 1649.

${ }^{84}$ Las fineças mal logradas. Título indicado por Barbosa Machado (Bibliotheca Lusitana, tomo II, p. 187) e conservado no elenco das suas obras por publicar em Edgar Prestage, D. Francisco Manuel de Mello, p. 599. Sobre a idade em que escreveu Las fineças mal logradas, pronunciou-se D. Francisco Manuel do seguinte modo: "Anno critico, e climaterico se não da vida, da quietação dos homens, táobem por isso muitas vezes da vida", em carta indicada no local acima citado de Barbosa Machado, a qual igualmente se desconhece. Las finezas malogradas teriam sido escritas quando tinha 18 anos (Edgar Prestage, D. Francisco Manuel de Mello, p. 33, n. 2).

${ }^{85}$ Joan Estruch, Entre la historia y la novela, p. 107; sobre "um sentir moderado pela razáo», vide Rui Manuel da Rocha Rufino, Sentir moderadamente: a influência do pensamento senequista nas Cartas Familiares de D. Francisco Manuel de Melo. Porto: [s. n.], 1996, diss. de mestrado, polic., pp. 58 s. 
estava entáo a caminho daquela idade estimada pelas damas como galante, e valorosa pelos inimigos, como enunciou e reforçou: "costumam ser Martes todos os filhos de Cúpido» ${ }^{86}$.

Com imaginação idêntica à do romancista, no entanto, prefiro antes assinalar que por volta de 1625 percorria ainda Portugal o sentimento unido da nobreza que em 1624 acorreu em defesa da Baía, retomada no ano seguinte, sobre a qual o jovem D. Francisco Manuel teria escrito «um poema em oitava rima» para celebrar o evento, segundo alguns biógrafos, embora Edgar Prestage diga desconhecer os fundamentos em que se baseiam ${ }^{87}$. Até 1640 , não haverá outro gesto militar uníssono, em comunhão com Espanha, como o de 1624.

No ano de 1625, a ameaça da armada inglesa era real, embora tivesse acabado por atacar apenas Cádis. Foram então levadas a efeito obras no presídio de Cascais, nas muralhas de Lisboa, abertura de trincheiras perto do palácio do governo, convocação de companhias específicas na capital, recrutamento de terços e armamento do país ${ }^{88}$, azáfama militar que o próprio D. Francisco Manuel referirá ao tratar da Epanáfora Trágica ${ }^{89}$.

${ }^{86}$ Epanaphoras, pp. 256 e 276.

${ }^{87}$ Edgar Prestage, D. Francisco Manuel de Mello, p. 34, continuação da nota anterior. Nesta expedição tomou parte um militar e homem de letras, D. Francisco de Portugal (1585-1632), que por sinal acabará também por conhecer a prisão no castelo de Almada em 1628 (de 6 de Maio de 1628, onde já se encontra, a 30 de Dezembro, pelo menos), por «aceitar e depois não querer» ir à Índia, e que nos legou, para além da obra literária, uma preciosa correspondência enviada a D. Rodrigo da Cunha, entre 1616 e 1631, com apreciaçôes políticas, literárias e da corte em geral. Nela se indica, em carta enviada para Braga, com data de 26 de Outubro de 1627, «as muzas não são pa todos os tempos eu tornarey $\mathrm{p}^{\mathrm{a}}$ tras esse pouco que tinha andado adiante em caza de hũ Dom fran. ${ }^{\text {co }} \mathrm{M} .^{\mathrm{el}}$ se eixercitão os engenhos do lugar q̃ sáoTibeos" (Carlos Alberto Ferreira, «D. Francisco de Portugal. I. Elementos para a sua bio-bibliografia», Biblos, vol. XXII, tomo II, 1946, p. 661; o texto vem do número anterior, onde as cartas, cujo apógrafo não é de boa qualidade, são resumidas e por vezes comentadas). Quem será este D. Francisco? Em Janeiro anterior, recorde-se, havia naufragado o futuro historiador de que nos estamos a ocupar.

${ }^{88}$ Epanaphoras, p. 175. Temia-se o ataque a Lisboa de «armadas inimigas» (Edgar Prestage, D. Francisco Manuel de Mello, p. 431, doc. 4). Documentação sobre a defesa de Lisboa encontra-se publicada em Eduardo Freire de Oliveira, Elementos para a história do municipio de Lisboa, tomo III. Lisboa: Typographia Universal, 1888, pp. $162 \mathrm{s.}$ Em 23 de Novembro de 1626, a câmara de Lisboa deliberou a propósito dos 40000 cruzados que emprestou ao governo "para a despesa do socorro de Cascais e das trincheiras que se fizeram o veráo do ano passado" (Eduardo Freire de Oliveira, Elementos, tomo III, p. 240). Crítica ao descuido de defesa e louvor à nova ordem de organização de companhias, a bem do comércio, foi registada por Duarte Gomes Solis, Alegación en favor de la compañia de la India Oriental [...]. [s. 1.: s. n. ],1628, fl. 285 r. Em 21 de Julho de 1626 foi autorizado que se despachassem para Portugal 15000 armas, sob proposta do Conselho de Guerra (Biblioteca Nacional de Espanha, ms. 2848, no 3). Certamente para distribuir pelo reino, como decorre da ordem régia de 21 de Janeiro de 1626, enviada à comarca de Viseu, por exemplo, para serem repartidas mil armas de fogo e 800 picas (Alexandre de Lucena e Vale, Um século de administração municipal: Viseu, 1605-1692 .[S. 1. : s. n.], 1954, pp. 87-88; sep. da Revista Beira Alta, vol. 13 - 1955, data da capa). Há múltipla documentação, a partir de 1622, sobre a reorganização militar do país. Para a distribuição das armas e seu pagamento, vide António de Oliveira, "Contestação fiscal em 1629. As reacçôes de Lamego e Porto", in idem, Movimentos sociais e poder, pp. 275-317.

${ }^{89}$ Vivência de naufrágio, não de batalha naval, a mais cruel entre todas as guerras, segundo o seu parecer experimentado (Politica militar, p. 48), de que nos transmitirá uma das maiores, a do Canal de Inglaterra, em 1639. Uma análise da Epanáfora Trágica em Maria Lucília Gonçalves Pires, "Epanáfora trágica. Viver e escrever a história», in Xadrez de palavras, pp. 175-186. Uma outra via, Jean Colomès, Critique et satire, cap. I, D. Manuel de Meneses morre no ano seguinte ao do referido naufrágio. D. Francisco Manuel compôs então uma Silva funebre, a qual não incluiu nas Obras Métricas, como relembra Maria Lucília Gonçalves Pires no trabalho acima citado, p. 180. Encontra-se publicada por Joan Estruch Tobella, «Un poema gongorino (inédito) de F. M. de Melo», in Manojueolo de estudios literarios ofrecidos a J. M. Blecua. Madrid: Ministerio de Educación y Ciencia, 1983, pp. 155-168, cit. pelo 
Com a vibração militar do momento, embora não tivesse já o pai para guiá-lo ${ }^{90}$, a varonia nobre e primogénita, para além da aventura, indicaram-lhe o caminho funcional, traçando a futura profissão de D. Francisco Manuel de Melo: as armas, a que se seguiria a diplomacia, funçôes acostumadas dos homens do seu estatuto social ${ }^{91}$. As Letras era uma outra via por que se lançavam os homens principais ${ }^{92}$, mas embora esta rua fosse mais curta do que a das armas, como se exprime, a predilecção foi para a milícia, «a mais gabada coisa que há no mundo», embora tivesse tanto de honrosa como de martírio, como a experiência lhe ensinará, não deixando, no entanto, de associá-la às letras ${ }^{93}$, numa figuraçáo cultural entre a nobreza muito diversa do tempo, por exemplo, de Inácio de Loiola antes da defesa de Pamplona em Maio de 1521.

A sua carreira militar foi truncada em 1644 , como bem se sabe ${ }^{94}$, não obstante a falta de comandos que existia no Portugal Restaurado, estando D. Francisco, mais uma vez,

autor; Maria Teresa Amado, A Representação do Poder, pp. 201-211 («Silva funebre primera en la morte de Don Manuel de Meneses capitan general de la armada real de Portugal».

${ }^{90}$ Cartas, p. 57, datada de 4 de Outubro de 1636. O pai, D. Luís de Melo, morreu na Ribeira Grande em 13 de Fevereiro de 1615 (Edgar Prestage, D. Francisco Manuel de Mello, p. 18).

${ }^{91}$ D. Francisco Manuel de Melo, A Visita das Fontes, pp. 70- 71.

92 Dava então indicaçóes sobre a escolha da profissão (armas ou letras) aos filhos dos outros, se o dele ainda não tinha nascido. (O autógrafo do diálogo Visita das Fontes está datado de 1657). O filho natural, D. Jorge Manuel, morreu em 1674. Segundo Barbosa Machado, teria nascido cerca de 1660, mas provavelmente muito antes, se efectivamente perdeu a vida em batalha. O embaixador D. Francisco de Melo tomou posse dos bens vinculados e de prazo na qualidade de seu parente mais próximo (o testamento de D. Jorge não o nomeava). As casas da rua das Pedras Negras, em Lisboa, pertencentes à Universidade de Coimbra, faziam parte deste conjunto de bens. Entre 14 de Novembro e 6 de Dezembro de 1677 estava a tentar-se a realização da escritura, uma data que apenas mostra que estava já morto D. Jorge Manuel. Em 1570, um Duarte de Leáo estava de posse destas casas (Simão de Figueiró, Livro da fazenda e rendas da Universidade de Coimbra em 1570 organizado por [...] escrivão das suas rendas e bens e lido e publicado por António Gomes da Rocha Madahil. Coimbra: por Ordem da Universidade de Coimbra, 1940, p. 276). Vide, a propósito, o nosso trabalho sobre A livraria de um canonista do século XVI. Coimbra: 1966. Separata da Revista da Universidade de Coimbra, vol. XXII (1970). Neste local se mostra também que Duarte Nunes do Leão, formado em Direito Civil e autor, entre outras obras, de Descripção do reino de Portugal, não foi ascendente de D. Francisco, como por vezes se diz, na esteira de Edgar Prestage.

${ }^{93}$ Vide A Visita das Fontes, pp. 238-239; Epanaphoras, pp. 380. À física contrariedade entre as armas e as letras, postulada pelos soldados, se refere o autor, por exemplo, em Epanapforas, p. 381. Reconhecia, no entanto, «el defecto que suelen tener los señores en el escribir» e exprime que «holgara de hablar a todos los señores tan cuidadosos de sus personas, partes y costumes, como suelen ellos ser de sus estados, de sus casas, sus coches, sus caballos y libreas" (Cartas, pp. 81-83). Sobre "o alcance nobilitante do saber», vide Paulo Silva Pereira, D. Francisco Manuel de Melo e o modelo do "cortesão prudente e discreto", pp. 367-374). Das Letras, de certas letras, não tinha boa recordação em 1657 , data em que dava o seu conselho sobre a escolha da carreira aos homens principais. D. Francisco Manuel conhecia já muito bem certos letrados, tornados familiares pelos trabalhos em que se viu envolvido em 1644, e de quem não gostava ( $A$ Visita das Fontes, p. 73), assim como critica, talvez por volta de 1649, "os professores de letras civis» que foram colocados nas correiçóes das comarcas e governo central, em favor do engrandecimento do poder régio (Epanaphoras, p. 27). As correiçôes, caídas em desuso nos finais do século XV, foram renovadas, mas não iniciadas, por D. João II. Já constam das Ordenaçôes Afonsinas (liv. I, t. XXIII).

${ }^{94}$ Edgar Prestage indica a data de 19 de Novembro de 1644 para a sua prisão acusado de assassínio. Há cartas de 6 de Julho e de 4 de Novembro, datadas «De aqui», que sugerem já estar preso nesta data. Cartas, p. 97; Benjamin Nicholaas Teensma, Dom Francisco Manuel (1608-1666) Varia bio-bibliografica. Lisboa: [s. n.], 1961, p. 4, sep. da revista Ocidente, LXI (1961). 
${ }^{95}$ João Franco Barreto denunciou a falsa autoria de La Victoria del Hombre, mas não foi capaz de dizer a verdade sobre os motivos da prisão de D. Francisco Manuel, os quais, com ou sem razão, não podiam deixar de ser do domínio público. Ao não dizer nada de concreto, creio, no entanto, que Franco Barreto disse tudo: «per varios subçeços não esquizitos a sua idade, e proffiçáo, lhe imputarão um crime de major imcomveniente que descreditto" (Bibliotheca Luzitana, tomo III, fls. 464v-465, exemplar fotocopiado da BNP; Virgínia Rau, Cartas de D. Francisco Manuel de Melo a Duarte Ribeiro de Macedo. Publicadas com um estudo introdutório por [...]. Lisboa: Publicaçóes da Revista da Faculdade de Letras da Universidade de Lisboa, 1968, p. 14).

O Conselho de Guerra, apoiado pelos governadores das províncias, solicitou ao monarca, em 27 de Março de 1654, a comutaçáo do degredo do Brasil para uma das fronteiras portuguesas. Em vez de usar de clemência, cujas circunstâncias estão previstas nas Ordenaçôes Filipinas (liv. V), embora houvesse crimes que náo admitiam comutação ou perdão, o poder régio, pela mão do monarca, despachou na margem da consulta: «Eu trato de fazer justiça, não comodidades, e noto muito assi fazer se consulta sobre esta matéria, como pedirem no os governadores das armas».

Documentos conhecidos e há muito publicados e aproveitados. (A consulta, com data de 27 de Março de 1654, encontra-se publicada por Gastão de Melo de Matos, «Documentos inéditos sobre D. Francisco Manuel», Anais da Academia Portuguesa de História, II série, vol. 6, Lisboa, 1955, p. 188. Fonte já aproveitado por Virgínia Rau, Cartas, p. 24). Renovo-a para sublinhar a qualificação dada por João Franco Barreto ao crime cometido, transcrita na nota anterior. Ao mesmo tempo aproveito para assinalar uma característica de D. João IV, "o seu sentimento de justiça», aplicado também, por exemplo, a D. Sebastiăo César de Meneses e ao irmáo, Frei Diogo César, presos por inconfidência (colaboracionistas, em tempo de guerra, com os castelhanos). Não obstante a intercessão de altas personalidades em seu favor, o rei «a todos respondia com sincero pesar, náo poder satisfazer-lhes os seus pedidos, pois que a isso se opunham os seus sentimenttos de justiça», não concedendo perdão mesmo na hora da sua morte. Só depois do falecimento, na regência de D. Luísa, foram soltos e sob fiança» (Aida Antunes Pinheiro, D. Sebastiāo César de Meneses. Coimbra: [s. n.], 1963, pp. 25-26, diss. de lic., polic.; Frei Rafael de Jesus, Segundo volume da 18a parte da "Monarchia Lusitana Tomo II. Manuscrito original publicado por M. Lopes de Almeida, Damiāo Peres, César Pegado. Coimbra: Biblioteca Geral da Universidade, 1942, pp. 75-76). Era a «justiça, não as comodidades», de que o monarca tratava. O que bem pode explicar a atitude para com D. Francisco Manuel de Melo (e outros), o qual se aventurou à pena de morte, uma vez falecido o monarca, fugindo do desterro do Brasil em Março de 1658, «num jogo de perder ou ganhar» (Edgar Prestage, D. Francisco Manuel de Mello, pp. 291-292).

De acordo com as Ordenaçôes Filipinas, a pena a aplicar aos condenados para o Brasil que náo cumpriam o degredo era o da duplicação do tempo, no caso de condenação temporária, e a morte para os condenados para sempre (Ordenaçôes Filipinas, liv. 5, CXLIII). Sendo assim, D. Francisco arriscou a pena de morte, como referimos. Lembre-se que por decreto de 6 de Maio de 1654 foi notificado a L. A. de Mesquita, condenado pela Relaçáo a degredo para o Brasil, «que a todo o tempo que constar que elle se sahio do dito degredo, ou for achado fora delle, morra morte natural». O próprio Henrique Correia da Silva, preso no Limoeiro em 18 de Abril de 1628, por ter quebrado o degredo para África ao incorporar-se na força armada destinada a libertar a Baía em 1624, foi de novo remetido para Tânger «sem lhe acrescentar pena, com declaração, que o embarcarão preso». Valeu-lhe, certamente, o ter-se incorporado na jornada da Baía. (Citado por Carlos Alberto Ferreira, «D. Francisco de Portugal», Biblos, vol. XXII, p. 52). No que diz respeito ao Brasil, era fácil sair dele um degredado em virtude da condenação não estipular capitania onde residisse, norma jurídica que foi mudada em 18 de Janeiro de 1677, acabando com o genérico Brasil. Considerese, na intrincada história de todo o processo de D. Francisco, que pelo menos no reforço da prisão em 1650 intervém o Secretário de Estado: "foi sua a ordem de minha reclusão», o que deve ter invocado uma razão de Estado e o conhecimento do monarca (Edgar Prestage, D. Francisco Manuel e Mello, p. 250). O secretário de Estado, que não era seu amigo, chamava-se Pedro Vieira da Silva. Dirigiu a devassa contra Francisco de Lucena, que o conduziu à morte, substituindo-o no lugar de secretário, depois de ter também intervido na repressão dos levantamentos do Algarve. (Para a sua biografia, vide Rocha Martins, "Pedro Vieira da Silva", in Os Grandes vultos da Restauração de Portugal. Lisboa: Empresa Nacional de Publicidade, 1940, pp. 406-412; D. Francisco Manuel de Melo, Alteraçōes de Évora / 1637, introdução e notas de Joel Serrão. Lisboa: Portugália Editora, 1967, pp. 122-123, nota; António de Oliveira, Movimentos sociais e poder, pp. 597-598, texto e nota). Por esta altura, D. Francisco tinha "grandes e grandes ministros» a seu lado (Cartas, p. 392), mas que lhe não puderam valer em 1654, impondo-se a vontade régia. 
de um homem, uma vez livre da acusação de assassinato ${ }^{96}$. Tempo em que se viu impedido de continuar nos efectivos teatros da guerra, embora sobre eles desse conselhos, como o da defesa da barra de Lisboa, por sinal cogitada a partir das observaçóes que fez a partir do local onde então se encontrava preso, a Torre Velha ${ }^{97}$. E quando o perdão régio surgiu, na fase decisiva da Guerra da Restauração ${ }^{98}$, D. Francisco Manuel de Melo não retoma as armas, depois de tantos anos sem as praticar. Colocou então o seu cosmopolitismo, cortesania e experiência de vida ao serviço da diplomacia de Portugal ${ }^{99}$ e, mais uma vez, combate com a pena ${ }^{100}$, colaboração que nunca recusou, mesmo quando na prisão.

D. Francisco Manuel, moralista e melancólico, pelo menos a partir de 1637, como acentua Prestage ${ }^{101}$, era um militar, mas não um belicista. $\mathrm{Na}$ oração com que termina $E l$ Mayor Pequeño, pede o patrocínio do biografado não apenas para si, família real e pátria, mas também para a "católica paz» de todas as coroas cristãs ${ }^{102}$. Mas era a guerra a sua profissão e não admira, por isso, que ao voltar-se para a escrita de Marte ${ }^{103}$ se ocupasse da

\footnotetext{
${ }^{96}$ Vide Edgar Prestage, D. Francisco Manuel de Mello, pp. 185 s. e 423 s., doc. no 1, «Primeiro memorial».

${ }^{97}$ Sobre esta torre e as condiçốes materiais do espaço onde se encontrava retido, vide Pedro de Aboim Inglez Cid, A Torre de S. Sebastião de Caparica e a arquitectura militar do tempo de D. João II. Lisboa: Ediçóes Colibri, 2008.

${ }^{98}$ Em 11 de Abril de 1660, ainda Dom Francisco Manuel «não estava livre de perseguiçóes» (Edgar Prestage, $D$. Francisco Manuel de Mello, p. 297). Tinha, forçosamente, grandes apoios políticos que certamente o livraram de nova prisão e de novo processo, vindo definitivamente a ser perdoado do desterro perpétuo e do seu quebramento (sendo este formalmente justificado por motivo de doença) em 30 de Julho de 1662, por ocasiáo da graça concedida ao tempo do advento do rei D. Afonso VI. Perdóes acostumados ao tempo de "públicas alegrias e novos governos». Para além de dezoito anos de infortúnio (embora o texto da chancelaria aponte para vinte, mais ou menos), "por ter sido culpado na morte de Manuel Francisco Cardoso", Melo havia pago as penas pecuniárias em que havia sido condenado, obtido perdão das partes ofendidas, aspectos indispensáveis à obtenção de perdão, sendo considerado, ao mesmo tempo, o "seu zelo e suficiência», tornando-o digno de ser ocupado no «serviço público deste reino" (AN/TT, Chancelaria da Ordem de Cristo, liv. 47, fl. 261, registo; encontra-se publicado por Teófilo Braga, História da Literatura Portuguesa III Os Seiscentistas, pp. 223-224. O original da Chancelaria tem a anotaçáo a lápis de estar publicado por «Teófilo nos Seiscentistas em 1916»). Recorde-se que a regência de D. Luísa havia terminado em 26 de Junho e que D. Gregório Taumaturgo, conde de Vila Nova de Portimáo, morreu em «11 de Abril ou Maio de 1662» (Fernando Campos).

${ }^{99}$ Em 27 de Outubro de 1662 é-lhe dada a instrução, assinada pelo conde de Castelo Melhor, relativa à sua ida a Parma. Da mesma data é a instrução para Roma (Edgar Prestage, D. Francisco Manuel de Mello, pp. 330 s.).

${ }^{100}$ Em 1664, sob pseudónimo, escreve as duas intervençóes: Declaracion que por el reyno de Portugal ofrece el doctor Geronymo de Santa Cruz [...]. Lisboa: en la imprenta de Antonio Craesbeecky, 1663; Demonstracion que por el reyno de Portugal agora ofrece el Doctor Geronimo de Santa Cruz [...]. Lisboa: na officina de Antonio Craesbeek de Mello, 1664. A Declaracion encontra-se republicada por António Cruz, Papéis da Restauração. Selecção e estudo prévio por [...], vol. 2º. Porto: Marânus, 1969, pp. 105-142.

101 Edgar Prestage, D. Francisco Manuel de Mello, pp. 82-83. Pelas Cartas familiares "perpassa uma visão amargurada de um mundo mentiroso, mau, perigoso, cheio de «sem razóes», maldito, enfim, um mundo pouco propício a uma vida tranquila, onde pairam as incertezas e as ameaças» (Rui Manuel da Rocha Rufino, Sentir moderadamente: a influência do pensamento senequista nas Cartas Familiares de D. Francisco Manuel de Melo, p. 10).

${ }^{102}$ El mayor pequeño vida, y muerte del serafin humano Francisco de Assis / recuerdalas a la piedad universal D. Francisco Manuel. Lisboa: por Manuel da Sylva, 1647, fl. 163.

${ }^{103}$ Como o autor se exprime em a Política Militar, cuja oferta ao conde-duque tem a data de 20 de Abril de 1638 , os diversos livros existentes sobre matérias de guerra incidiam «sólo a la defensa u ofensa material, así en los ejércitos como en las plazas» («Al que leyre»). Os cuidados do capitão-general «no es tan proprio el arte del obrar como la del mandar obrar a los otros». Sobre a escrita teórica e prática da matéria de guerra, vide Rui Bebiano, A pena de marte.
} 
teoria do mando do general, que vinha a propósito numa determinada fase da sua vida ${ }^{104}$, da evolução da armada portuguesa em tempo filipino ${ }^{105}$, ou do mundo turbulento ao ocupar-se da escrita da história coeva.

Náo apenas, certamente, por ter vivido os acontecimentos, ao modo das Histórias de Tácito e não dos seus Anais ${ }^{106}$, ou por considerar a vida como milícia, neste ponto o contraditório de ócio ${ }^{107}$, mas também porque eram estas temáticas a que sobretudo se dedicavam os que professavam a história, recente ou mais antiga. Por outras palavras, eram os feitos militares, as acçóes gloriosas, heróicas, as que sobretudo faziam parte do objecto historiográfico de então.

5.

Às «Histórias», explicitou Antonio de Solís y Ribadeneyra (1610-1686), na dedicatória a Carlos II, em 1684, da sua Historia de la conquista de Mexico, costumava a Antiguidade chamar «livros de reis». Os livros de história são os livros dos reis, "porque se compóem de suas acçôes e sucessos» ou porque «o seu principal ensino visa directamente a arte de reinar» ${ }^{108}$.

A História, na verdade, era uma disciplina que fazia parte da educação dos príncipes. Para a educação do príncipe Baltazar Carlos, por exemplo, a quem D. Francisco Manuel, como seria de esperar, dedicou poesia laudatória ${ }^{109}$, foi lembrado ao seu mestre, Juan Isasi Idiáquez, em 1634, que «la historia es una viva representación de lo passado que da documentos grandes y enseña para librarse de algunas cosas en que otros príncipes an sido

Escrita da guerra em Portugal e na Europa (sécs. XVI-XVIII). Coimbra: Minerva, 2000; Luís Costa e Sousa, $A$ arte na guerra. A arquitectura dos campos de batalha no Portugal de Quinhentos. Lisboa. Tribuna, 2008, pp. 53 s.

${ }^{104}$ Vide, adiante, n. 316.

${ }^{105}$ Epanaphoras, pp. 165 s., narração necessária à compreensão dos acontecimentos focados, constituindo, ao mesmo tempo, uma crítica à organização e funcionamento das instituiçôes de guerra do seu tempo, como sublinha Jean Colomès, Critique et satire, pp. $17 \mathrm{~s}$.

${ }^{106}$ Demetrio Estébanez Calderón, Diccionario de términos literarios. Madrid: Alianza Editorial, 1999, p. 511, entrada «Historia e Historiografía».

${ }^{107}$ Antonio Bernat Vistarini, Francisco Manuel de Melo, p. 56; «La vida es milicia; la muerte batalla» (El mayor pequeño..., p. não numerada).

${ }^{108}$ Antonio de Solís y Ribadeneyra, Historia de la conquista de Mexico, población y progressos de la America septentrional conocida por el nombre de Nueva España. Madrid: en la imprenta de Bernardo de Villa-Diego, 1684. Consultámos a edição de 1863 incluída na «Biblioteca de Autores Españoles. Historiadores de Sucesos Particulares», tomo 2, sendo da p. 205 as citaçōes referidas. O autor era «secretario de su Majestad, y su cronista mayor de Indias». Fueter considera que «El libro carece de valor historico» (Historia de la historiografia, vol. I, p. 332). Outras apreciaçōes em Juan Luis Alborg, Historia de la literatura española, tomo II. Madrid. Editorial Gredos, 1993, pp. 927-930.

${ }^{109}$ Obras Métricas, vol. I, pp. 18 e 19. 
notados» ${ }^{110}$. Para além desta lição, o príncipe tinha necessidade de conhecer a história dos seus reinos futuros, havendo composto o cronista-mor Frei António Brandão, em 1634, um Directorio sacado de las vidas $i$ hechos de los esclarecidos Reies de Portugal ${ }^{11}$, destinado à aprendizagem do herdeiro de Filipe IV. E caso mais sintomático se passou com o próprio Filipe IV, que já depois de ser rei procurou instruir-se através da História ${ }^{112}$, chegando a traduzir Francisco Guicciardini ${ }^{113}$, cuja História de Itália leu como leitor-autor e sob cifra política, e a formar uma biblioteca instalada na Torre Alta do Alcácer de Madrid, de cujo índice, elaborado em 1637 por Francisco de Rioja ${ }^{114}$, se destaca a História como a disciplina mais representada, constituindo com a Poesia metade das matérias, com 1007 entradas, na sistematização de Fernando Bouza ${ }^{115}$.

Com os estudos de História estavam intimamente ligados os de Política, indispensável à formação de um príncipe. A História «ocupa no pensamento de Lípsio lugar-charneira», na expressão de Martim de Albuquerque ${ }^{116}$, e, naturalmente, em todos os que se dedicavam à política.

D. Francisco Manuel de Melo, que estudou a educação de D. João, duque de Bragança, não deixou de sublinhar que não foi educado para a majestade, atribuindo a $\mathrm{D}$.

${ }^{110}$ Fernando Bouza, El libro y el cetro. La Biblioteca de Felipe IV en la Torre Alta del Alcázar de Madrid. Madrid: Instituto de Historia del Libro y de la Lectura, 2005, pp. 150 e 31; idem, "Proprio Marte. Majestad y autoridad en la Alta Edad Moderna», in idem, Corre manuscrito [...]. Madrid: Marcial Pons, 2001, p. 308.

${ }^{111}$ BNE, ms. 2850, 74 fls. Vide Fernando Bouza, La herancia portuguesa de Baltasar Carlos de Austria: El Directorio de fray Antonio Brandão para la educación del heredero de la monarquía católica, "Cuadernos de Historia Moderna». Madrid: Universidad Complutense, vol. 9 (1988), pp. 47-62 (corre na internet); António de Oliveira, D. Filipe III. Lisboa: Temas e Debates, 2008, pp. 265-266.

112 Como ele próprio escreveu no Epílogo da tradução: «El leer historias también me pareceó punto muy esencial para conseguir el fin a que encaminaba mis deseos de alcanzar noticias, pues ellas son la verdadera escuela en que el Príncipe y Rey allarán ejemplares que seguir, casos que notar, y medios por donde encaminar a buenos fines los negocios de su Republica» (Cartas de Sor María de Jesús de Agreda y de Filipe IV. Edición y estudio preliminar de Seco Serrano, Carlos, ed., $2^{\circ}$ vol. Madrid: Atlas, 1958, p. 232). Igualmente aproveitado por Fernando Bouza, El libro y el Cetro, pp. 148 s., e António de Oliveira, D. Filipe III, pp. 108 s. Era na História, repetia-se em 1730, na censura do Santo Ofício para publicação de um texto pretensamente atribuído a Manuel de Meneses, feita pelo Pe. Frei Manuel da Consciência, que os reis «podiam aprender os dictames mais acertados para o governo, as direcçóes mais prudentes para a vida, os arbítrios mais uteis para o bem comum dos seus Povos, os modos mais proprios para a observancia das suas leis, e os meios mais eficases para a conservação dos seus estados [...]. (Chronica do muito alto, e muito esclarecido principe Dom Sebastiáo [...]. Lisboa: Officina Ferreyriana, 1730). Matéria comum nos diversos autores.

${ }^{113}$ Fernando Bouza, El libro y el cetro, pp. 147-148 e 152-154; idem, "Proprio Marte. Majestad y autoria", pp. 303 s.; "Uma parte do labor de tradução" de Filipe IV incidiu também na obra do sobrinho de Francisco, Guicciardini Luigi, Descriptión de todos los Paises Bajos, conocidos también como Baja alemania (1567), que aproveitou igualmente para sua formação (R. A. Stradling, Felipe $I V$, p. 440, n. 36); António de Oliveira, $D$. Filipe III, p. 109. Sobre a apreciação historiográfica de Francisco Guicciardini, vide Fueter, Historia de la historiografía, vol. I, pp. $84 \mathrm{~s}$.

${ }^{114}$ Fernando Bouza, El libro y el cetro, pp. 39 s.

${ }^{115}$ Fernando Bouza, El libro y el cetro, pp. 77-78.

${ }^{116}$ Martim de Albuquerque, Um percurso da construção ideológica do Estado. A recepçáo lipsiana em Portugal: estoicismo e prudência política. Lisboa: Quertzal, 2002, p. 33. 
João IV um deficiente conhecimento de política ou, pelo menos, do latim erudito para a alcançar, se bem que esta, como fez Filipe IV numa tendência então em voga, poderia ser aprendida pela experiência transmitida através das obras de História, não necessariamente já em latim, delas brotando uma nova ciência, a Política ${ }^{117}$.

Náo foi por acaso, certamente, que D. Francisco Manuel de Melo, no Hospital das Letras, deu entrada aos livros de história a seguir aos políticos, nem que, por exemplo, a projectada academia palatina de Artes Liberais no Alcázar de Madrid, proposta nos meados da década trinta do século XVII, incluísse entre os temas da Política «las Historias y Respúblicas y Leys» ${ }^{118}$. Ou que o infante D. Fernando, indo a caminho do governo de Flandres, não deixasse de ordenar ao embaixador em Roma, então o marquês de Castelo Rodrigo, Manuel de Moura, que solicitasse autorização papal para ler quaisquer livros políticos, ainda que proibidos, argumentando, exactamente, que, por causa do governo em que estava investido, «lhe parecia ser necessário ler alguns deles» ${ }^{119}$.

Compreende-se, assim, para de novo citar Solís Ribadeneyra, que os historiadores tivessem «por seu o magistério dos maiores ouvintes» ${ }^{120}$. A História, com efeito, «esta dedicada a la enseñança de los Grandes», repete, com outros, o Padre Pierre Le Moyne (1602-1671), religioso da Companhia de Jesus ${ }^{121}$. É através do conhecimento das histórias, dirá por sua vez Cabrera de Córdoba, que se alcança «a prudência, táo necessária na arte de reinar» ${ }^{122}$, havendo-se já Maquiavel dedicado à história na medida em que interessava às suas concepçóes políticas ${ }^{123}$.

Nada melhor do que a experiência, dirá por seu turno Botero (1540-1617), para aperfeiçoar a prudência «e o bom governo da república». E, como afirma, «a melhor experiência é a dos mortos. O homem aprende através do teatro da história com comodidade, à custa dos outros»" ${ }^{124}$.

${ }^{117}$ Tácito, p. 5.

${ }^{118}$ Fernando Bouza, El libro y el cetro, p. 75.

${ }^{119}$ Fernando Bouza, El libro y el cetro, p. 71. Sobre Manuel de Moura, vide Martínez Herrnandéz, «Os marqueses de Castelo Rodrigo e a nobreza portuguesa na monarquia hispânica», Ler História. Lisboa: Associação de Actividades Científicas, vol. 57 (2009), pp. 20 s.

${ }^{120}$ Antonio de Solís y Ribadeneyra, Historia de la conquista de Mexico, p. 205.

${ }^{121}$ Pierre Le Moyne, Arte de historia. Escrito en lengua francesa por el Padre [...] y traducido en la castellana por el Padre Francisco Garcia [...]. Madrid: en la Imprenta Imperial, 1676, p. 216. As conversas do mestre de príncipes, no domínio da História, «son con los Reyes, y sus Ministros, y con los Generales e los Exercitos». Por isso, o decoro não sofre "que ande con trage vulgar" (p. 216).

${ }^{122}$ Luis Cabrera de Córdoba, De Historia para entenderla y escrivila, p. 11.

${ }^{123}$ Ed. Fueter, Historia de la historiografia, vol. I, pp. 79-80.

${ }^{124}$ João Botero, Da Razão de Estado. Prefácio de Luís Reis Torgal. Tradução de Raffaella Longobardi Ralla. Coimbra: Instituto Nacional de Investigação Científica, 1992, pp 40-41. O que vai entre aspas tem uma parte que adaptámos. Não é pura citação. 
A história passa, assim, a ser um guia das acçóes políticas, induzidas da experiência, que era a história ${ }^{125}$, num momento em que a ciência nova, de raiz matemática e experimental, se começava a constituir ${ }^{126}$. «Os exemplos passam a ser matéria de observação», no dizer de Maravall ${ }^{127}$, e da experiência, que é história, são induzidas as «leis» da política, nova ciência, as quais não são mais do que «uma experiência acumulada e transmitida através de exemplos» ${ }^{128}$, chegando Sancho de Moncada, em 1619, a propor a criação de uma nova faculdade do saber para o efeito, necessariamente instalada na corte ${ }^{129}$. Os livros denominados de política irão proliferar, assim como os de história, de onde as experiências políticas deviam ser sacadas directamente ou pela via didáctica dos aforismos ${ }^{130}$. "A notícia das historias da

125 «A experiencia he a guia do entendimento, regra da vontade, alma da prudencia: sem ella nem na paz se pode governar, nem na guerra acertar» (Sebastiâo César de Meneses, Summa politica, p. 29). Sobre o autor, vide Martim de Albuquerque, Um percurso da construção ideológica do Estado, cap. V, com bibliografia.

${ }^{126}$ Para o valor da expeeriência na elaboração do novo conhecimento, vide, por exemplo, Steven Shapin, $A$ evolução científica. Lisboa. Difel, 1999, pp. 94 s. Sobre experiência e história: Joel Serrão, "Introdução» a Francisco Manuel de Melo, Epanapforas, p. XLII s.; José Antonio Maravall, «Empirismo y pensamiento Político (Una question de orígenes)", in Estudios de Historia del Pensamiento Español Serie III El Siglo de lo Barroco. Madrid: Centro de Estudios Políticos y Constitucionales, 1999, pp. 17-38; Modesto Santos Lopéz, «Experiencia e historia en el pensamiento político español del siglo XVII», in Peña Xavier, coord., Poder y Modernidad. Concepciones de la Politica en la España Moderna. Valladolid: Universidad de Valladolid, pp. 105-125; José A. Fernández-Santamaría, Razón de Estado y política en el pensamiento español del Barroco (1595-1640). Madrid: Centro de Estudios Constitucionales, 1986, pp. 123 s. e 144). Considere-se, no entanto, que D Francisco Manuel, como por exemplo Saavedra Fajardo, «conhecia o risco de governar por exemplos». Para este, José A. Fernandéz-Santamaría, ibidem, pp. 219 s.

${ }^{127}$ José Antonio Maravall, «La idea de la historia en Fray Pedro Simón», in Historia del Pensamiento, vol III, p. 458.

${ }^{128}$ Antonio Perez, Suma de preceptos justos, necesarios y provechosos en Consejo de Estado al Rey Felipe III, siendo príncipe. Aforismos sacados de la História de Publio Cornelio Tácito. Intodución e notas de Modesto Santos). Madrid: Anthropos, 1991, p. XII. Na biblioteca real portuguesa existia um exemplar de uma edição francesa de Cornélio Tácito, em $4^{\circ}$, pasta, o qual foi avaliado em 800 réis no inventário post-mortem de D. Pedro II.

${ }^{129}$ José Antonio Maravall, «Un primer proyecto de Facultad de Ciencias Políticas en la crisis del XVII. El "Discurso VIII" de Sancho de Moncada", in Estudios de Historia, vol. III, pp. 117-149; Modesto Santos, "Introdución» e «Hacia una ciencia política...» in Antonio Perez, Suma de preceptos pp. XI e s. Sobre a nova ciência como modo de superar a fase final da concepção organicista da história de Espanha, que impregnava a cultura, considere-se Ángel Rivero Rodríguez, «Política y políticos en el tiempo de Felipe III: Tácito, Séneca, Lipsio, in José Martínez Millán e Maria Antonietta Visceglia, dirs., La monarquía de Felipe III: la Casa del rey (volume II). Madrid: Fundación MAPFRE / Instituto de Cultura, 2008, pp. 136-148.

A marcha da história como instrumento de acção política, desde há muito que se encontrava aberta, nomeadamente, entre os espanhóis, com Sebastián Fox Morcillo (ca.1526-ca.1560)) ou Juan Páez de Castro (c.1512-1570). Vide Maria Teresa Amado, A Língua do Ver, vol. I, p. 355 e idem, A Representaçâo do Poder, p. 80; Jenaro Costas Rodríguez, "La historiografía hispano-latina renacentista...», pp. 52-57. Fox Morcillo foi autor, entre outras obras que lhe granjearam renome de neoplatónico, de De Historiae Institutione. Dialogus (1557), a qual está publicada, em tradução portuguesa, por Maria Teresa Amado, A Lingua do Ver, de que nos servimos. Uma tradução espanhola encontra-se em Antonio Cortijo Ocaña, Teoría de la historia y teoría política en el siglo XVI. Sebastián Fox Morcillo De historiae institutione dialogus = Diálogo de la enseñanza de la historia (15557). Alcalá: Universidad de Alcalá de Henares, Servicio de Publicaciones, 2000, volume que não conseguimos consultar.

130 «La obra de Tacito encaja con la corriente barroca, que destaca ante todo el uso de la razón natural que busca en la historia modelos que puedan servir para resolver en las grandes materias de Estado» (Modesto Santos, "Introdución» in Perez, Antonio, Suma de preceptos, p. XIII ). Sobre razōes que justificam a divulgação em Espanha de Justo Lípsio, vide infra, n. 140. 
authoridade nos negoceos da republica, grangea respeito, como viva experiencia», explicitará, por sua vez, Sebastião César de Meneses, em $1649^{131}$.

A experiência política extraída da História sairá, no entanto, dos figurinos historiográficos criados por Tácito. No desenvolvimento da contra-reforma política, e sobretudo depois de Maquiavel ter sido colocado no Índice, em 1559, o historiador Tácito transforma-se então em político, como se encontra explicado no Hospital das Letras ${ }^{132}$ ou no Epitome de Manuel Faria e Sousa, em texto muito paralelo ${ }^{133}$, tornando-se, para Justo Lípsio (15471606), uma «alternativa do Florentino, seu par ou sucedâneo», na expressão de Martim de Albuquerque $^{134}$, tendo-o temperado através da doutrina do neoestoicismo.

Justo Lípsio chamou a atenção para o valor político de Tácito já em 1572 e ao publicar as suas Políticas ${ }^{135}$, em 1589, extraiu dele a maioria das citaçóes contidas nesta obra ${ }^{136}$, a qual é «uma tentativa de compromisso entre a moral e as condiçôes da acção eficaz» ${ }^{137}$.

Como se exprime D. Francisco Manuel de Melo, os seis livros sobre as Políticas tinham aparência não de um livro, «mas uma cadea de sentenças de sabios, dirigidas ao proveito dos príncipes e respúblicas», apreciação correcta que o denominado Lípsio, que é o próprio Melo, naturalmente aceita em conferência de especialistas que tratam da saúde dos livros, reunidos em hospital simbólico ${ }^{138}$.

A obra de Justo Lípsio teve larga recepção em Portugal, encontrando-se um exemplar das suas obras na própria livraria do rei D. Pedro II, no qual, certamente, como já foi notado, não tocaria ${ }^{139}$, encontrando-se igualmente as Politicas, na tradução castelhana de 1604, na biblioteca de Filipe IV.

${ }^{131}$ Summa Politica, pp. 32-33. Outras expressóes semelhantes, tiradas da Arte de Furtar ou de Pedro Barbosa Homem, Discursos de la juridica y verdadera razon de Estado, formados sobre la vida y acciones del Rey don Juan el II de buena memoria, Rey de Portugal, llamado vulgarmente Principe Perfecto. Contra Machavelo y Bodino y los demas politicos de nuestros tiempos sus sequazes. Coimbra: Nicolao Carvalho, 1626, in António de Oliveira, Movimentos sociais e poder, p. 149, n. 34.

${ }^{132}$ Hospital das Letras, p. 212.

${ }^{133}$ Manuel de Faria y Sousa, Epitome de las Historias portuguesas dividido en quatro partes: Por [...]. Adornado de los retratos de sus reyes con sus principales hazañas. Bruxelas: por Francisco Foppens, 1677, fls. 3-3v.

${ }^{134}$ Martim de Albuquerque, Um percurso da construção ideológica do Estado, p. 35.

135 Politicorum sive Civilis Doctrinae Libri Sex, quid ad Principatum maximè Spectant [...], as quais foram traduzidas para castelhano nos princípios do século XVII: Los seis libros de las políticas o doctrina civil de Justo Lipsio, que sirven para gobierno del reino o principado. Madrid: Juan Flamenco, 1604, tradução de Bernardino de Mendoza. Há edição moderna de Javier Peńa Echeverría e Modesto Santos López. Madrid: Tecnos, 1997.

${ }^{136}$ Martim de Albuquerque, Um percurso da construção ideológica do Estado, p. 30, referenciando a contagem de Peter Burke. No índice dos autores citados, no início de Politicorum sive civilis doctrinae libri sex, Cornélio Tácito aparece destacado.

137 Expressão atribuída a Christian Lazzeri, segundo Martim de Albuquerque, Um percurso da construção ideológica do Estado, p. 31, extraída de «Le gouvernement de la raison d'État».

${ }^{138}$ Hospital das Letras, p. 207. A obra de Lípsio escapou à censura portuguesa até 1597 , mas não já ao índice de 1624 (Martim de Albuquerque, Um percurso da construção ideológica do Estado, pp. 71 s., onde e encontram explicados os motivos de tal situação).

${ }^{139}$ Martim de Albuquerque, Um percurso da construção ideológica do Estado, p. 164. 
Em Portugal, o «tacitismo puro» não teve grande aceitaçáol ${ }^{140}$, procurando-se antes a teorização de uma política cristã através de outros historiadores, como João de Barros ${ }^{141}$ e, nomeadamente, por meio da história de $\mathrm{D}$. João $\mathrm{II}^{142}$, político então muito em voga, ou de outros exemplos extraídos de autores notáveis ${ }^{143}$.

D. Francisco Manuel de Melo, moralista, opunha-se-lhe politicamente, embora tenha sido historiograficamente influenciado por Tácito ${ }^{144}$ e Justo Lípsio ${ }^{145}$, para além de utilizar com certa abundância as suas máximas no decorrer da argumentação de Astrea Constante ${ }^{146}$.

Certamente que também escreveu um Tácito Português, a partir da «vida, morte, ditos e feitos» de D. João IV, experiência fundadora de nova política ${ }^{147}$. Redigiu igualmente

${ }^{140}$ Martim de Albuquerque, Maquiavel e Portugal. Estudos de História das Ideias Políticas. Lisboa: Aletheia Editores, 2007, p. 81. Sobre tacitismo, para além da obra referida, vide Enrique Tierno Galván, «El tacitismo en las doctrinas políticas del Siglo de Oro espańol», in Escritos (1950-1960). Madrid: Tecnos, 1971; Baltasar Álamos de Barrientos, Discurso politico al Rey Felipe III al comienzo de su reinado. «Estudio introductorio» de Modesto Santos. Madrid: Anthropos, 1990, pp. 7 s. Para a recepção do tacitismo em Espanha, com bibliografia, vide Beatriz Antón Martínez, El tacitism en el siglo XVII en España. Valladolid: Secretariado de Publicaciones, Universidad, 1992; idem, «El humanista flamengo J. Lipsio y el receptio del tacitismo en Espańa», in Humanismo y pervivencia del Mundo Clásico, vol. I, pp. 237-249; Jorge del Palacio Martín, «Las 'Politicas' de Justo Lipsio. Un ensayo sobre el poder de las ideas», in José Martínez Millán e Maria Antonietta Visceglia, dirs., La monarquía de Felipe III: la Casa del rey (volume II), pp. 148-160. Sobre vias da "política cristã», vide Luís Reis Torgal, Ideologia Politica e Teoria do Estado na Restauração. Coimbra: Biblioteca Geral da Universidade, 1982, pp. 135 s.

${ }^{141}$ Fernando Albia de Castro, Aphorismos y exemplos politicos y militares: sacados de la primera Decada de Juan de Barros. Lisboa: Pedro Craesbeeck, 1621. Existia na biblioteca de Filipe IV. Sobre o autor, vide Martim de Albuquerque, Um percurso da construção ideológica do Estado, pp. 75 s. De João de Barros explicitou D. Francisco Manuel: «[...] porque se bem alguns críticos o caluniaram de casual e quase incivil, pela inteireza com que se não diverte a alguma apóstrofe ou aforismo político, basta que insensivelmente os deixe com grande arte embebidos na narração ..." (Hospital das Letras, p. 254).

${ }^{142}$ Pedro Barbosa Homem, Discursos de la juridica y verdadera razon de Estado; António de Oliveira, «Para a história do embargo à publicação de D. Agostinho Manuel de Vasconcelos, Vida y acciones del rey Don Juan el Segundo, in idem, Movimentos sociais e poder, pp. 143-157; idem, "A censura historiográfica no período filipino. Uma nota para o seu estudo", in ibidem, pp. 159-171.

${ }^{143}$ Eugenio Narbona, Dotrina civil, escripta por aforismos: sacados de la dotrina de los sabios, y exemplos de la experiencia. Madrid: por la viuda de Cosme Delgado, 1621.

${ }^{144}$ Jean Colomès, Critique et satire, pp. 179-181, na apreciação de Historia de los Movimientos; Joan Estruch Tobella, "Introducción» à sua edição de Historia de los movimientos, p. 30; Marcelino Menéndez y Pelayo, "La historia considerada como obra artistica", p. 22; Paulo Silva Pereira, D. Francisco Manuel de Melo e o modelo do "cortesão prudente e discreto», pp. 50 e 283 s.

145 Cartas, p. 512; Benjamin Nicolaas Teensma, Don Francisco Manuel de Melo, pp. 120-121; Martim de Albuquerque, Um percurso da construção ideológica do Estado, pp. 117-125.

146 «El Tacito, que todo lo dexó advirtido a los monarcas» (Astrea, p. 95). Cita também Lípsio nas suas Políticas.

147 Sobre a existência de diversas cópias desta obra inacaba, vide Benjamin Nicholaas Teensma, «Um manuscrito desconhecido do Tácito Portuguêz de Dom Francisco Manuel de Mello», Revista de Portugal. Série A. Língua Portuguesa. Lisboa, no 201, vol. XXVII, (Janeiro, 1962), pp. 75-102. O mesmo autor deu depois indicação de uma outra edição de Tácito, que diz encontar-se in 1640. Revista bibliográfica, vol. 1, Lisboa, 1940). Esta obra de Melo estava a ser escrita por volta de 1650 (Tácito, p. 50). Um Tácito espanhol havia aparecido em 1614, mas nada tem a ver com a estrutura da obra de Melo. Trata-se de uma tradução de obras de Tácito com aforismos tirados destas obras e impressos nas margens do texto traduzido (Tacito español ilustrado con aforismos, por Don Baltasar Álamos de Barrientos, 1535-1624, já acima citado). Na livraria de D. João IV existia um exemplar desta tradução, em pergaminho, o qual foi avaliado em 1200 réis à morte de D. Pedro II. Um Tacito 
Verdades pintadas e escritas, o que pressupóe uma psicologia da conduta. Mas esta obra, segundo Barbosa Machado, «constava de cem emprezas morais, debuxadas por sua mão, e ilustradas com discursos» ${ }^{148}$. Se os emblemas eram morais, só poderiam pertencer à política com o intuito da sua moralização, dada a má impressão que D. Francisco Manuel tinha dos políticos ${ }^{149}$.

Afirmou Jean Colomés que D. Francisco foi «de la jeunesse à la mort, passionné de politique, aussi bien des idées théoriqies que de l'action gouvernementale publique ou secrète» ${ }^{150}$. Aparentemente, basta considerar que no mesmo ano em que publicou a Guerra de Cataluña, embora continuando preso desde 1644, participou na polémica contra um texto anónimo escrito a pedido de Filipe IV sobre como recuperar Portugal, compondo para o efeito o Ecco Polytico ${ }^{151}$. Seguiram-se diversos trabalhos de índole histórica, elaborados ao mesmo tempo que outros de géneros diferentes, alguns deles solicitados pelo poder régio em datas diversas, como D. Teodósio, Manifesto ${ }^{152}$, Declaración, Demonstración, Astrea Constante

Portuguez, ou traduçam politica dos tres primeyros livros dos Annaes de Cornelio Tacito, foi publicado por Luis do Couto Feliz. Lisboa: Na Off. Real Deslandesiana, 1715.

A edição do Tácito português, de D. Francisco Manuel de Melo, certamente que necessita de uma edição crítica, como já em 1947 reclamava Mário de Sampayo Ribeiro, numa recensão crítica à obra de Jean Colomés, Hispanisants portugais du XVII'me siécle. D. Agostinho Manuel de Vasconcelos et la défense des Braganes. Coimbra, 1947, 52 páginas, a qual foi publicada na revista Biblos, vol. XXIII, tomo I (Janeiro-Abril), 1947, pp. 227-234. Sampayo Ribeiro era de opiniấo que os apógrafos existentes do Tácito Português, estavam «claramente deturpados nos primeiros livros, e cuja autoria (pelo menos tal como se nos apresenta redigida) não pode ser atribuída sem fundas reservas a $\mathrm{D}$. Francisco Manuel de Melo». "[...] O Tácito português deve-se evidentemente à pena de inimigo jurado da Casa de Bragança e, até, da causa portuguesa e ati-maquiavélica». Remete, depois, para as p. 53 e 54 da ediçáo de 1940. Nestes pontos, pelo menos, não deve ter razão em virtude da documentação hoje conhecida.

${ }^{148}$ Bibliotheca Lusitana, tomo II, pp. 187-188. Continha 14 emblemas «com o mesmo corpo e letra e allegoria» dos que se encontravam em Diego Saavedra Fajardo (1584-1648), Idea de un principe politico representada en cien empresas, segundo carta de Melo citada por Barbosa Machado e datada de 14 de Dezembro de 1649. A obra de Saavedra havia já tido ediçóes a partir de 1640 (Munique: Emprenta de Nicolao Eurico).

${ }^{149}$ Os emblemas destinar-se-iam, pelo menos, à educação do príncipe, a qual não poderia deixar de ser moral. Alguns deles, a darmos crédito à referida carta de Melo, que actualmente se desconhece, coincidiam com 14 dos de Saavedra, como indicámos em nota anterior. Outros conteúdos poderiam ser da natureza dos que o Prof. Vistarini expôs e interpretou a partir da poesia, na conferência que pronunciou neste colóquio.

${ }^{150}$ Jean Colomés, D. Francisco Manuel et la littérature française, in «V Colóquio Internacional de Estudos Luso-Brasileiros Coimbra 1963. Actas». Volume III: Coimbra: [s. n.], 1966, p. 491.

${ }^{151}$ Ecco polytico: Responde en Portugal a la voz de Castilla [...]. Lisboa: por Paulo Craesbeck, 1645. A obra saiu só no ano seguinte, sem embargo da data no título, dado que as últimas licenças são de 16 e 17 de Janeiro de 1646 (Edgar Prestage, D. Francisco Manuel de Mello, p. 208, n.). A dedicatória ao monarca está datada da Torre de Belém (S. Vicente do Restelo) a 11 de Junho de 1645. Sobre a apreciação do Ecco e dos polemistas portugueses que intervieram na matéria, vide Maria Teresa Amado, A representação do poder, pp. 126-132. O eco é a resposta, por questóes, ao que diz o "papel anónimo». Um exemplar desta obra, em pergaminho, $4^{\circ}$, existia na biblioteca real portuguesa, o qual foi avaliado, à morte de D. Pedro II, por 200 réis.

${ }^{152}$ Manifesto de Portugal. Lisboa: por Pablo Craesbeeck, 1647. Encontra-se republicado em António Cruz, Papéis da Restauração, vol. 2º pp. 84-103. Publicação por «orden de su Magestad». Mandado fazer pelo Conselho de Estado (Cartas, p. 308; Epistola declamatoria, p. 120, ed. de 1720). O poder régio mandou depois distribuir a obra pelo reino e conquistas, o mesmo acontecendo no estrangeiro, através dos seus embaixadores (D. Teodósio, p. 32). Foi o tempo, no entanto, como o autor anotou, «que eu (também por ofícios de meus émulos), era de novo condenado a perpétuo desterro para entre bárbaros, como homem indigno de viver em companhia dos outros» (ibidem). 
e El Pueblo Lusitano ${ }^{153}$, tornando-o um escritor de intervenção na política oficial, actividade que parece que não desgostava, a crer na opinião que emitiu sobre o Eco Político ${ }^{154}$, embora o trabalho tivesse sofrido críticas $^{155}$, levando-o de momento a cuidar de estudos seráficos, acabando, no entanto, na fase final da vida, por ser encarregado de missóes diplomáticas. Mas a diplomacia era a arte da dissimulaçáo, e, naturalmente, também a da prudência. $\mathrm{E}$ sobretudo, a política tinha por vezes seguir o que era útil, como já ensinara Lípsio, não se detendo na distinção «entre as coisas virtuosas e não virtuosas», objecto da Ética, não da Política ${ }^{156}$.

Mas a política dos estadistas, ao desterrar a «franqueza e a verdade», sentenciou D. Francisco Manuel em Guerra de Cataluña, fez do engano ciência ${ }^{157}$. E ao considerar, em El fenis de Africa, que nem todos são convenientes para ministros, grandes ou príncipes, remata confiscando aos políticos qualquer ponta de moralidade, os quais, como homens, inventaram outra filosofia, «donde no ay distincion entre, util, y honesto» ${ }^{158}$, o que denota não ter sido apagado, pelo menos em termos práticos, um certo maquiavelismo da realidade política que podia passar amparada por Séneca e Tácito, sendo este «uma tinha universal, pegada na cabeça dos monarcas» ${ }^{159}$.

Ao tempo ainda do seu longo e atribulado julgamento, na corte de Lisboa liam-se e ensinavam-se, como se exprime, as «artes e tretas aos Tácitos e Maquiavelos» ${ }^{160}$. E na Aula Política $^{161}$, justifica a secura do seu trabalho como um bem, em virtude de se encontrar

${ }^{153}$ Vide Edgar Prestage, D. Francisco Manuel de Mello, pp. 248; Maria Teresa Amado, A representação do poder, pp. 123-125, tendo publicado, no vol. II, Astreia Constante (fls. 81-115 v) e El pueblo lusitano (fls. 117-130).

${ }^{154}$ Cartas, p. 112; Edgar Prestage, D. Francisco Manuel de Mello, p. 209. No entanto, Melo esclareceu: «Não fui ministro, nem apeteço de o ser, nem Deus permita, que em dano público, minha honra se aumente, como sucederia, quando com insuficiencia manejasse algum negocio comum» (Aula Politica, p. 6).

${ }^{155}$ Cartas, p. 239.

${ }^{156}$ Martim de Albuquerque, Um percurso da construçâo ideológica do Estado, p. 35, a quem pertence a expressão entre aspas. Para a problemática actual da ética nas Ciências Sociais, vide Sottomayor Cardia, Racionalismo, consciência metodológica. Lisboa: INCM, 1996, pp. 155 s. Sobre as ideias políticas de D. Francisco Manuel de Melo, vide Maria Teresa Amado, A representação do poder; pp. 29 s.; José Manuel Prazeres; Paulo Silva Pereira, D. Francisco Manuel de Melo e o modelo do "cortesão prudente e discreto», pp. 277 s. As Cortes da Razão, que Barbosa Machado intitula Cartas (sic) de la Razón Idea politica (Bibliotheca Lusitana, tomo, II, p. 188), não deviam constituir um texto de pura política (Cartas, p. 345 e respectiva anotaçáo). No elenco das obras que apresentou em Obras Morales, Melo colocou Cortes de la Raçon entre as que denominou de «Exquisitas». As razóes «são as melhores as que são para todos» (Cartas, p. 345).

${ }^{157}$ Guerra de Catalunha, p. 328; má impressâo das «políticas», Hospital das Letras, p. 239.

${ }^{158}$ El fenis de Africa, p. 171.

${ }^{159}$ Hospital das Letras, p. 211. Martim de Albuquerque, Maquiavel e Portugal, pp. 76 e 80.

160 Cartas, p. 184; Edgar Prestage, D. Francisco Manuel de Mello. p. 224. Para uma apreciação contra Maquiavel e Bodin, Hospital das Letras, p. 213. Recorde-se, a propósito, que embora considerando que D. João II actuou "com grande severidade desacostumada» no caso dos Braganças, reconhece que, como príncipe cristáo, «mostrou não confundir a rectidão com a política, distinguindo na pena os culpados dos inocentes» (D. Teodósio, p. 109). Um dado autobiográfico?

${ }^{161}$ Edgar Prestage dá indicação de uma cópia manuscrita existente na Biblioteca Nacional do Brasil com a data de 1653 (D. Francisco Manuel de Mello, p. 584, nota), onde declara supor tratar-se de uma cópia destinada ao príncipe. Na biblioteca real estaria também um manuscrito do Tácito Português, embora nenhuma das obras 
«livre dos escuros laços da eloquência de Patérculo [19 a.C. - 31 d.C] e das ambíguas sentenças de Tácito».

Estava a querer justificar, certamente, um estilo breve, repudiando o das prolixas crónicas, mas não o do estilo que impunham os aforismos e era usado na poesia, moral ou mesmo por alguns historiadores ${ }^{162}$. Estilo com brevidade, mas recheado, aos modos de Tácito ${ }^{163}$, a partir da compreensão do autor.

A história não podia ser escrita de modo seco, limitar-se apenas a expor os factos, como acontece, por exemplo, com D. Manuel de Meneses, na «ocupação de cronista» ${ }^{164}$. Com efeito, a história «se quer vestida, e revestida de juízos, sentenças, secretos, malícias e discriçóes; porque, enfim, uma História nua, sobre desonesta, é desaproveitada» ${ }^{165}$. À seca expressão das relaçóes, antecipação da escrita metódica dos finais do século XIX, uma escrita temperada pela mundividência do historiador.

Esta tomada de posição, feita no contexto explicativo de como o historiador Tácito se tornou político, é autorizada por D. Francisco, no entanto, dentro das «artes de história»,

conste do inventário dos bens de D. Pedro II, provavelmente incluídas na parte em que as espécies que nela figuravam não puderam ser inventariadas individualmente).

${ }^{162}$ Em França sobressaiu Pierre Mathieu (1563-1621), conhecido em Espanha como Pedro Mateo (Jean Colomés, D. Francisco Manuel de Melo et la littérature française, pp. 498-499, onde são indicadas obras do autor e as referências que lhe faz D. Francisco Manuel, o qual ainda cita, entre os historiadores franceses, René de Ceriziers, para além de outros anteriores, como Commynes). Na sua Histoire de Louis XI (1610), Pierre Mathieu «fait suivre la narration d'une longue liste de sentences estraites des Mémoires de Commynes et classées par thèmes». «O estilo que uza, imitado de Tácito, suscitou admiradores e opositores», como se adverte no texto que estamos a aproveitar. Em Itália seguiu-o Malvezzi (Jean Laffond, «Le champ littéraire des formes brèves», in Moralistes du XVIIe siècle De Pibrac à Dufresny. Jean Laffont, ed. Paris: Robert Laffont, 1992, p. 6. Vide também Paulo Silva Pereira, D. Francisco Manuel de Melo e o modelo do cortesäo prudente e discreto, p. 501; local onde se encontram dados, com bibliografia, sobre Malvezzi (pp. 493 s.).

${ }^{163}$ Como se exprimiu Martim de Albuquerque, seguindo Mark Morford: «Ninguém como Tácito escreveu história - em que pôs dinamismo, colorido, dramaticidade, pragma, tensão ética - e a história, vinque-se bem, para Lípsio é teatro, espelho, mestra e exemplo da vida» (Martim de Albuquerque, Um percurso da construçäo ideológica do Estado, pp. 33-34). O que já vinha da transmissão ciceroniana do De Oratore (Jenaro Costas Rodríguez, «La historiografía hispano-latina renascentista», in Humanismo y pervivencia del Mundo Clásico, vol. I, 1993, pp. 42-44).

${ }^{164}$ Redigiu boa parte da crónica de D. Sebastiáo e «escreveo em mar \& porto, a restauração da Bahia, tambe区 por expresso mấdamento delRey: hũa, \& outra erão historias secas, \& de extraordinario estilo, porém fiel». Mesmas características na posterior relação que escreveu do naufrágio de 1627 (Epanaphoras, pp. 268-269). A relação do naufrágio encontra-se republicada por Joel Serrão, in Epanaphoras, pp. 582-601 e foi recentemente traduzida para francês (cf., n. 41). Uma versão da "Recuperação da cidade do Salvador», in Revista do Instituto Histórico e Geográfico Brasileiro, XXII, 1859, pp. 357 s. O manuscrito da Crónica de D. Sebastiäo esteve localizado no convento de Alcobaça, segundo Barbosa Machado (Bibliotheca Lusitana, III, p. 312). Sobre a autoria da crónica que saiu sob o seu nome em 1730, na Oficina Ferreiriana, vide, para além de Barbosa Machado, Inocêncio Francisco da Silva e outros (Diccionário Bibliográphico, vols. VI e XIII), e Joaquim Veríssimo Serrão, A historiografia portuguesa, vol. II, p. 153 e vol. III, pp. 133-159, para D. Sebastiāo. Vide n. 82 e 89.

${ }^{165}$ Hospital das Letras, p. 212. Orientaçáo comum dos historiadores de então, como transparece da opiniấo de Agostinho Manuel de Vasconcelos, parente de D. Francisco Manuel: a história não se pode escrever apenas com a verdade dos acontecimentos: «tiene sequedad» a história onde se náo "descubran los consejos i se haga examen dellos». Recorde-se que D. Agostinho Manuel de Vasconcelos, ao considerar a história como mestra da vida, entende que «ninguna parece mas justa de proponerse, que las de Principes excelentes, para que los imiten los que alcançan la gran fortuna de reinar» (António de Oliveira, «Para a história do embargo à publicação da obra de D. Agostinho Manuel de Vasconcelos...”, in idem, Movimentos sociais e poder, pp. 148-149. 
apenas pelo italiano Agostino Mascardi (1590-1640), único tratadista de história que parece citar, cuja Dell 'Arte historica trattati cinque teve ediçôes em 1636 e 1648, para além de outras ${ }^{166}$. De 1611 datava a obra de Luís Cabrera de Córdoba (1559-1623), De historia, para entenderla y escribirla ${ }^{167}$, a qual certamente conheceu, como tem sido referido e cujas qualidades didácticas se impóem ${ }^{168}$, se bem que os modelos possam ser criados a partir da leitura de obras histórias ${ }^{169}$.

\section{6.}

Se as obras de história se destinam a fornecer liçóes aos que detinham o poder, os que unicamente gozavam de honra heróica, se «o historiador passa a ser considerado um profissional com efectiva capacidade interventiva no governo da sociedade presente», na expressão de Teresa Amado ${ }^{170}$, a selecção dos factos só poderia ir numa direcção.

É a D. Afonso VI que D. Francisco Manuel oferece as Epanaphoras, "como histórias heróicas», enquanto à rainha de Inglaterra dedica as Moralidades e ao infante D. Pedro, pela sua idade, as Obras Métricas. Alguns dos sonetos que publicou em Obras Métricas levam a qualificação de heróicos pela matéria que tratam, a qual igualmente se reflecte nas principais

${ }^{166}$ Agostino Mascardi, Dell 'arte historica trattati cinque, in questa ultima impressione, con ogni diligenza rivisti, e corretti. Roma: per Giacomo Facciotti, 1636. Edição mais completa: 1648. Na BNE, encontra-se referenciada uma edição de 1655. Sobre a primeira informação, vide Maria Luisa Doglio, «Mascardi, Agostino», in Dizionario Critico della Letteratura Italiana a cura di Vittore Branca, vol. II. Turim: UTET, 1973, pp. 547-549, artigo que consultei na internet. No Hospital das Letras, p. 246, Melo considera o tratado «livro de grande e bem logrado estudo».

${ }^{167}$ Esta obra de Luís Cabrera de Córdoba existia na biblioteca da Torre Alta, de Filipe IV, mas em 1637 foi catalogada na rubrica «Libros varios de diversas linguas», denotando ainda a dificuldade de classificação da sua matéria.

${ }^{168}$ Joan Estruch Tobella, na introdução à sua edição de Historia de los movimientos, pp. 26-28. Como objectivo do volume, Cabrera de Córdoba indicou: «Escrivo la importancia de la historia, la del buen historiador, las partes que ha de tener, las de la legitima, y perfeta historia, y como se hara tal» («Al teatro»). Sobre os tratadistas da História em Espanha, vide Maria Teresa Amado, A Lingua do Ver.

${ }^{169}$ Uma delas, referida em Historia de los movimientos, p. 294, foi a de D. Diego Hurtado de Mendoza (15031575), Guerra de Granada [...]. Lisboa: Giraldo de la Vińa, 1627, 1ª ed., o qual imitou Tácito. («Escriviô la historia da ultima guerra de Granada seguiẽdo mucho el estylo de Tacito con excelente linguaje, i modo de dezir inimitable». "[..] es absolutamente la mejor que se escrivió en nuestra lingua», fl. Av. Esta edição contém um acrescento de Don Juan de Silva, conde de Portalegre, fls. 100v-102v, o qual também escreveu uma «introducción». O manuscrito publicado, o «mas original», foi corrigido por Lavanha a partir da lição que possuía o conde de Portalegre. «Este texto es el que sigo sin alterarle en nada, i es el genuino i proprio de quiẽ en su introdució habla aquel gran Conde», "Al Lector»). Outros historiadores, obviamente, foram influenciados por Diego de Mendoza. Manuel de Faria e Sousa enumera entre os seus mestres, depois de indicar nomes da Antiguidade: «[...] tengo delante a Don Diego de Mendoça en la de Granada, y a Antonio de Fuen-Mayor en la de Pio Quinto; y a Mariana en la General, y a Barros, y a Osorio, y a Mafeo, en la Indica, que son los que mas atinaron con el verdadero modo de historiar no imitei cada uno a todos los maestros, ni a uno solo en todo, y algunos dellos a uno en poco [...]». Exposição integrada numa «Satisfacion apologetica a lo de que tuvo noticia averse notado por algunos en esta Historia quando salio la primera vez» (Manuel de Faria e Sousa, Europa portuguesa, vol. I. Lisboa: Antonio Craesbeeck de Melo, 1678, p. 16; trata-se da «segunda edicion correta, ilustrada, y añadida en tantos lugares, y con tales ventajas que es labor nuevo por su autor»).

${ }^{170}$ A Lingua do Ver, p. 242. 
obras de história, onde, forçosamente, invoca «casos memoráveis», como naturalmente reclama para a Guerra de Cataluña ${ }^{171}$.

Embora D. Francisco Manuel de Melo privilegie os factos praticados pelos heróis, necessariamente de natureza política ou militar, também neste ponto, no entanto, se afasta do sentir comum. Não são já os tempos de glória que apresenta em Guerra de Cataluña, mas o das «adversidades, sidiciones, trabajos y muertes» provocados por uma guerra civil ${ }^{172}$. Náo tem sentido acrescentar glória aos que morrem ou ficaram feridos em Montjuic, quando adquirida «en tan siniestro día para su nación ${ }^{173}$. Matéria triste ${ }^{174}$, trágica, de guerra civil, mas que ainda assim pode servir de exemplo numa concepção determinista da sociedade: «Ah, señores, lleno está el mundo de historias y las historias llenas de sucesos que nos encaminan a la templanza» ${ }^{175}$.

Bom senso do conde de Ońate, como consultor. Mas venceu o partido da guerra, o do não senso ${ }^{176}$. Desde o tempo de D. Fernando o Católico, ajuíza D. Francisco Manuel no Eco político, não sucederam «reboluciones, y levantamientos» que não tivessem sido motivados pelos que mandam ${ }^{177}$.

A Guerra de Cataluña, como é arquisabido, é um modelo literário de história. Um outro «modelo linguístico e literário» é a História do México, de Solís ${ }^{178}$. Mas entre uma e outra há diferenças muito grandes.

Solís apresenta «um argumento de histórias grandes», «rico em façanhas triunfais e em maravilhosos golpes da fortuna», como já acentuou Eduardo Fueter ${ }^{179}$. Trata de heróis, "glorificando Cortés e esquecendo a tragédia dos Aztecas», como também já foi dito ${ }^{180}$, enquanto Melo fala de soldados, no sublinhado de Picón, acerca de um século, na

${ }^{171}$ Historia de los movimientos, p. 71. «El que ha de escrivir los sucesos de un Principe, lo q primero ha de referirr, es los exercitos, fuerças y grãdezas q̃ passe en su Imperio [...]» (Baltasar Álamos Barrientos, Tacito español, p. 193, aforismo I. 37).

${ }^{172}$ Historia de los movimientos, p. 73.

${ }^{173}$ Historia de los movimientos, p. 384.

${ }^{174}$ Historia de los movimientos, p. 74.

${ }^{175}$ Historia de los movimientos, p. 164.

${ }^{176}$ Como já acentuou Joan Estruch, o voto do conde de Ońate apresentado por D. Francisco Manuel, embora revestido de retórica, corresponde à versão que dele faz J. H. Elliott, La rebelión de los catalanes, pp. 402-404. Os vassalos «públicamente pedían y deseaban la paz» (Historia de los movimientos, p.74). Entre os conselheiros de estado, o $5^{\circ}$ conde de Ońate (Íńigo Vélez de Guevara y Tassís) «fazia gala de certa independência», no ajuizar de J. H. Elliott, El conde-duque de Olivares. El político en una época de decadencia. Traducción de Teófilo de Lozoya. Revisión de Antonio Feros y el autor. Barcelona: Grijalbo Mondadori, 1998, p. 645.

${ }^{177}$ Ecco, fl. 8v.

${ }^{178}$ Desta obra existia um exemplar na biblioteca dos reis portugueses, o qual, em pergaminho, foi avaliado em 1500 réis à morte de D. Pedro II. Por sinal, a «Historia de Catalunha por D. Francisco Manuel», em quarto e pergaminho, que fazia parte da mesma biblioteca, valia 200 réis.

${ }^{179}$ Ed. Fueter, Historia de la historiografía moderna, vol. I, p. 332.

${ }^{180}$ Enciclopédia Wikpedia, na internete. 
introdução que fez para a edição de 1912 da obra de D. Francisco Manuel ${ }^{181}$. Por outro lado, este não deixou de louvar Tácito, nos Anais, embora seja "coisa de muito admirar», como observa, o ter "descido a falar de coisas tão pequenas como a venda das hortas dos histrióes e as valas do Tibre» ${ }^{182}$. Querendo imitá-lo, assumiu o compromisso, na obra sobre D. Teodósio, de «não esquecer nenhuma circunstância referente ao seu assunto, por medo de baixar, referindo-o» ${ }^{183}$, se bem que reconheça que nem tudo serve à história ${ }^{184}$.

As referências à história das coisas banais, na Guerra de Catalunha, não revelam cor local, são descriçôes tópicas ${ }^{185}$. Mas estão inseridas as instituiçôes no meio geográfico e social a que respeitam e, sobretudo, tanto nesta obra, como na Epanaphora Politica, com muitos pontos em comum, revela-se um extraordinário cultor da história social, desejando que as memórias que apresenta, como projecta em $D$. Teodósio, sejam úteis náo apenas ao Príncipe, mas também à Nação ${ }^{186}$.

A Guerra de Cataluña é um título sincopado, como se sabe, que se usa por comodidade de citação, mas que não revela o seu conteúdo, ao contrário do título estirado da primeira ediçãa $^{187}$, o qual é composto por três partes, sendo as duas primeiras referentes à Historia de los movimientos, y separacion de Cataluña. A terceira, a guerra entre Filipe IV e a «Deputación General» deste Principado ${ }^{188}$.

A obra, no seu conjunto, sofreu as primeiras grandes críticas no século XIX, vindas em primeiro lugar, segundo parece, a partir de França, segundo Teensma ${ }^{189}$. Em Espanha, uma das apreciaçóes ficou a dever-se a Menéndez y Pelayo, proferida em $1883^{190}$.

${ }^{181}$ Jacinto Octavio Picón, em «Introducción» à Historia de los movimientos, separación y guerra de Cataluña [...] nuevamente publicada pela Real Academia Espańola. Madrid. Libreria de los Suc. de Hernando, impresores y Libreros, 1912, p. LIV.

${ }^{182}$ D. Teodósio, p. 43.

183 «No sólo sirven a la república las obras heroicas» (Historia de los movimientos, p. 73). O Tácito, por exemplo, é «obra do mais útil e não do mais grande», como esclarece (p. 1-2). Fox Morcillo, por sua vez, havia escrito em 1557: «náo se há-de escrever tudo o que é verdadeiro e tudo o que aconteceu se nem for útil, nem deleitoso de modo a aliciar facilmente o leitor pela sua utilidade e pelo seu agrado» (De Institutione, p. 13). Transcrito de Maria Teresa Amado, A Lingua do Ver, p. 245, n. 49).

${ }^{184}$ Por incerta ou muito inconveniente. Para estes factos, "costumo valer-me da arte para tornar menos clara uma passagem se alguma surge em que devesse fazer omissão» (D. Teodósio, p. 43).

${ }^{185}$ Historia de los movimientos, p. 146.

${ }^{186}$ D. Teodósio, p. 200.

${ }^{187}$ Clemente Libertino, Historia de los movimientos, y separacion de Cataluña, y de la guerra entre la magestad catolica de Don Felipe el cuarto rey de Castilla, y de Aragon y la Deputacion General de aquel principado. Lisboa: Paulo Craesbeek impresor de las Ordens Militares, 1645.

${ }^{188} \mathrm{Na}$ dedicatória ao Papa Inocêncio X, intitula-a, como mais consentânea, Historia de la separación del Principado de Catalunha y su primero rompimiento en guerra com el rey católico Don Felipe IV el Cuarto.

${ }^{189}$ Benjamin Nicolaas Teensma, Don Francisco Manuel de Melo, p. 119, citando Eugène Rosseeuw Saint- Hilaire, Histoire d'Espagne depuis les premiers temps historiques jusq à la mort de Ferdinand VII. Nouvelle éd., rev. et corr., T. XI. Paris, 1873, p. 61, nota. Esta edição encontra-se na Biblioteca Nacional de Holanda (BNH), mas os repertórios digitais indicam ediçóes anteriores, a começar em 1837. Não tive oportunidade de verificar qualquer das ediçóes.

${ }^{190}$ No discurso de ingresso na Real Academia de la Historia, intitulado La historia considerada como obra artistica. Encontra-se publicado nas suas Obras completas, vol. VII de Estudios y discursos de crítica Historica y Literari. Santander: Aldus, S. A. de Artes Gráficas, 1942, pp. 21- 22. Este vol. é o XII da «Edición nacional de 
Embora entenda que a Guerra de Cataluña seja «una obra excepcional, o más bien única, de tétrica y solemne belleza, rica en amarguras e desengaños, aguzados con profundidades conceptuosas», não lhe atribui a categoria de história, mas antes a de um «folheto político de acerbísima oposición, hábilmente disimulada con aparencias de histórica mansedumbre». Em vez de censor, Melo apresenta-se como um «enemigo oculto», onde a «indulgencia tiene trazas de lúgrebe ironia». Por outro lado, é uma obra «donde encontró voz por caso único en nuestra literatura, la tremenda elocuencia de los tumultos populares».

Menéndez y Pelayo, no seu discurso sobre filosofia da História através da expressão literária, náo podia advinhar que cerca de um século depois eram precisamente os levantamentos populares que estavam no centro da historiografia económico-social, dando nova visibilidade e importância à Guerra de Cataluña e às Alteraçóes de Évora e não propriamente à história dos feitos militares e políticos, desvalorizada ao tempo da afirmação de novas correntes historiográficas, embora de novo aguerrida através da escrita dos modos da guerra e de quem a faz, de que a proliferação de biografias régias, de governantes ou militares são expressôes diversificadas ${ }^{191}$.

Os movimentos populares em Catalunha têm por causas próximas o aboletamento dos militares. Os soldados, em campanha ou a caminho dela, «não são os homens bisonhos nascidos nas aldeias ou tirados dos sectores artesanais ou de vagabundagem dos centros urbanos», como acentuou Yves-Marie Bercé ${ }^{192}$. O soldado, «nómada, guerreiro e ocioso de momento passa a pertencer a uma sociedade acima das leis, em contraste com a comunidade de onde saiu e se aloja, sedentária e pacífica», na formulação do mesmo autor ${ }^{193}$. Os bandos gerais relembram aos soldados a disciplina e, a lei, a obrigatoriedade do seu acolhimento, mas a fome e a situação de guerra potenciam a sua força e os desmandos fora e dentro das casas sossegadas que os acolhem. D. Francisco Manuel de Melo, que nos soube transmitir a desumanidade do recrutamento, em que por vezes se viu envolvido, condoendo-se ${ }^{194}$, não

las obras completas de Menéndez Pelayo». Citação aproveitada, por exemplo, em Benjamin Nicolaas Teensma, Don Francisco Manuel de Melo, p. 120. Para a crítica de Pujol y Camps, vide, adiante, n. 244 e texto.

${ }^{191}$ A biografia, como subgénero historiográfico, difunde-se no século XVII sob a forma «sentenciosa e glosada» (Ángel Ferrari). Citado por Jean Colomés, D. Francisco Manuel de Melo et la littérature française, p. 499, expressão extraída da obra de Ángel Ferrari Núñez, Fernando el católico en Baltasar Garcián. Madrid: Espasa Calpe, 1945. Pierre Mathieu, que em 1624 viu traduzido em castellano Pedazos de Historia y de Razon de Estado, teria sido um dos iniciadores do subgénero, seguido mais tarde de Malvezzi, no ajuizar de Colomés. A biografia foi cultivada em Portugal por diversos autores, entre eles D. Francisco Manuel de Melo. Sobre a a especificidade da sua abordagem, Luis Cabrea de Córdoba, De Historia, fls. 77v e s.). Para Portugal, convém relembrar, com anterioridade, André de Resende, Vida do infante D. Duarte, dirigida ao Senhor D. Duarte, duque de Guimaräes, seu fillho (1565), mas apenas editada no século XVIII (Lisboa: na Off. da Academia Real das Sciencias, 1789).

${ }^{192}$ Yves Marie Bercé, Histoire des croquants: étude des soulévements populaires au XVII siècle dans le sud-ouest de la France. Genéve: Librairie Droz, 1974, pp. 548 e s., "Les émeutes contre les gens de guerre», de onde é extraída a ideia. Sobre o levantamento de Jerez de la Frontera contra os soldados alemães, em 1664, vide Antonio Domínguez Ortiz, "Les mouvements populaires en Anadalousie au XVII ${ }^{e}$ siècle», in Jean Nicolas, ed., Mouvements populaires et conscience sociale XVI'-XVII siècles. Paris: Maloine S. A. Éditeur, 1985, pp. 295-296.

${ }^{193}$ Yves Marie Bercé, Histoire des croquants, p. 560.

${ }^{194}$ Epanaphoras, pp. 360-361 e 398 s. 
calou as vexaçóes dos soldados ${ }^{195}$. Opressóes inicialmente multiplicadas pela forçosa mobilidade dos exércitos de Filipe IV, obrigados por vezes a passar de uma província para outra, consoante os exércitos franceses acometiam ${ }^{196}$. Muito pior aconteceu quando o exército se repartiu "em vários quartéis, consoante a capacidade dos povos», sendo então proibido aos advogados colocar acçôes contra «as queixas comuns dos soldados». Ordem que fez ceder o dique da contençáo: «o último desconsolo do miserável é tirar-lhe a voz para pedir remédio», sentenciou D. Francisco Manuel $^{197}$. A resposta não podia ser outra que não fosse a vingança da agressão, originando em cadeia a revolta ${ }^{198}$ que culmina em revolução ao tempo da festa do Corpo de Deus ${ }^{199}$.

Uns três anos antes, em Agosto de 1637, também em Portugal se verificou um sismo socio-político, com epicentro em Évora, tendo por causa próxima o exarcebamento de uma epidemia de tributos, vindo a luta para a rua, depois de uma série de descontentamentos públicos iniciados pelo menos no Porto, em $1629^{200}$.

7.

Desde a primeira linha do texto introdutório da Guerra de Cataluña, ou, se se preferir, desde a dedicatória, D. Francisco Manuel de Melo, com alguma obsessão, como ocorre também nas outras suas obras de história, não cessa de afirmar que só escreverá verdades. $\mathrm{O}$ mesmo acontece com os outros historiadores, incluindo os que tratam de prodígios ${ }^{201}$, não deixando os tratadistas da História de insistirem neste ponto, seguindo velhos princípios, vindos já de Cícero ${ }^{202}$. O que cada historiador pretende é precisamente a reputação de verdadeiro. $\mathrm{O}$ autor da História de Portugal Restaurado, por exemplo, não desejava «maior

195 «Publicabánse cada vez más y mayores delitos de la soldadesca, escribíanse procesos, sacábanse desde los púlpitos memoriales, hablábanse en las plazas, motejábanse en las conversaciones y acusábanse desde los púlpitos. Todo el escándalo y descontentamento de los nobles y plebeos tenia por objecto la opresión de su pátria [...]" (Historia de los movimientos, p. 97).

${ }^{196}$ Historia de los movimientos, p. 83; J. H. Elliott, La rebelión de los catalanes, cap. 11, intitulado «La guerra con Francia".

${ }^{197}$ Historia de los movimientos, p. 98. «É a satisfação consequência dos justos benefícios, quando regularmente se parte. Ao contrário, dos injustos procede o queixume, dele a parcialidade, mãe da rebelião, ruína do seu Império» [do Príncipe] (Tácito, p. 43). Cf. J. H. Elliott, La rebelión de los catalanes, cap. 14, «Un ejercito al que alojar».

198 «Marchaban las compañias de unos lugares a otros y salián a recebillas armados los paizanos como a gente contraria (Historia de los movimientos, p. 105).

${ }^{199}$ Historia de los movimientos, p. 122. «La revolta dels pagesos va transformar-se en la revolución catalana repetim, contra els desigs de Barcelona», segundo J. Reglà, Els virreis de Catalunya, p. 117. Transcrevemos de Joan Estruch, Historia de los movimientos, p. 129, nota.

${ }^{200}$ António de Oliveira, "Contestação fiscal em 1629. As reacçôes de Lamego e Porto", in Movimentos sociais e poder, pp. 275-317.

${ }^{201}$ Gregório de Almeida, Restauração de Portugal Prodigiosa [...]. Lisboa: por Antonio Alvarez, 1643, pp. 23-24.

${ }^{202}$ Em matéria de História, Cícero (Orator 62) havia já estabelecido «três regras fundamentais: não dizer nada de falso; ousar dizer toda a verdade; evitar a menor suspeita de parcialidade, inspirada pelo favor ou inimizade» (Jenaro Costas Rodríguez, La historiografia hispano-latina, p. 43). 
recompensa que o reconhecimento de que até agora não saiu ao mundo história mais verdadeira, pois sem afeição, ódio, esperança ou temor, não perdoei a requisito algum, necessário para a história, que me ficasse para escrever [...]» ${ }^{203}$. D. Francisco Manuel, por sua vez, explicita que a História de Cataluña, lhe "grangeara opinião de verdadeiro» ${ }^{204}$. E numa carta, a um dos muitos amigos, desabafa: «Sofro muito bem o louvor à verdade da história que escrevi» ${ }^{205}$.

A insistência em afirmar que se escreve verdade em História, ciência como saber organizado, e a satisfação dos autores em serem autorizados como verdadeiros, depois de sujeitos à crítica, a qual por vezes era muito contundente e desencorajadora, revelam que seria muito vulgar não apenas o erro, mas também o falso em matéria de História, traduzindo possivelmente a falta de verdade uma expressão social que não escapou a Baltasar Gracián ${ }^{206}$.

Historiograficamente, com efeito, o século XVII amanheceu envolvido ainda no nevoeiro das falsidades do século anterior sobre a história antiga de Espanha e Portugal, vindas de Beroso e Ânio de Viterbo, popularizadas e acrescidas depois por historiadores naturais até meados de seiscentos ${ }^{207}$. São bem conhecidas, na verdade, as falsificaçôes de alguns humanistas italianos ${ }^{208}$, com infiltraçóes na historiografia portuguesa e espanhola, sentindo-se também D. Francisco Manuel de Melo na necessidade de joeirar a falsidade, socorrendo-se, entre outros, de Gaspar Barreiros ${ }^{209}$. Mariana (1536-1624), por exemplo, havia já negado, genericamente, a validade de Beroso, como acentua Caro Baroja, mas a primeira parte da Monarquia Lusitana conserva-se ainda no tempo da história de Portugal que vai do criação do mundo ao aparecimento de Cristo, como explicita o seu título, acima transcrito em rodapé, tendência das origens que, vinda de muito longe, se vai manter ainda. Posteriormente, os seus continuadores publicitarão documentos falsos, não importando, para agora, as razões deste acto em Portugal, acção que é igualmente praticada em Espanha ${ }^{210}$.

${ }^{203}$ Luís de Meneses, História de Portugal Restaurado, vol. I. Porto: Livraria Civilização, 1945, p. 8.

${ }^{204}$ D. Teodósio, p. 32.

${ }^{205}$ Cartas, p. 112.

${ }^{206}$ Uma crítica à falta de verdade na sociedade, em Gracián, Baltasar, El críticón. Edición de Santos Alonso. Madrid: Catedra, 1996, terceira parte, pp. 585 s.

${ }^{207}$ Julio Caro Baroja, Las falsificaciones de la historia en relación con la España. Barcelona: Seix Barral, 1992, p. 99.

${ }^{208}$ Ed. Fueter, Historia de la historiografía, pp. 149-151, referindo-se sobretudo a Annius de Viterbo, de nome Giovanni Nanni.

${ }^{209}$ Francisco Manuel de Melo serve-se de Beroso, mas com dúvidas, dado que tanto ele como Viterbo «são de suspeitosa fé, em seus escritos», baseando-se na censura do «eminentíssimo antiquário» Gaspar de Barreiros. Mas diz que tanto Beroso como Viterbo, certamente seguindo Barreiros «em o famoso livro de suas Memorias», foram adulterados por "João Aneo» (Epanaphoras, p. 217, ao descrever a Galiza). No mesmo local refere Floriáo do Campo (1495?-1558), com um "parece», quanto ao nome original de Pontevedra. Tem consciência da necessidade de estremar, "como he razão, as verdades das fabulas». A obra indicada de Gaspar Barreiros está datada de 1561 (vide, n. 18). Sobre histórias gerais de Galiza na primeira metade do século XVII, vide Fernando Bouza, «Dar Galicia y el gallego a la imprenta...", Obradoiro de Historia Moderna. Santiago de Compostela: USC Editora, 18 (2009), pp. 944. Foram, certamente, fontes de D. Francisco Manuel de Melo.

${ }^{210}$ D. Francisco Manuel de Melo considera o cronista dos reinos de Castela (1629) e de Aragão (1637) e cronistamor do rei (1640), José Pellicer de Ossau Salas y Tovar (1602-1679), como autor «fantastico, sobre incerto» (Hospital das Letras, p. 238). Por sua vez, R. O. Jones considera que «no es muy crítico y ni siquiere muy escrupuloso en quanto a datos y pruebas» (Historia de la literatura española, 2 Siglo de oro: prosa y poesía. Barcelona: Ariel, 1992, p. 281). 
Com esta actividade de falsificação, não admira, pois, que os historiadores se reclamem de verdadeiros e que a censura literária, agora também através do Desembargo do Paço ${ }^{211}$, esteja activa, embora nem sempre atenta, quanto à produção historiográfica.

Assim, por exemplo, em 1629, o predicador régio Frei Francisco de Jesus, representava, em contexto do parecer emitido sobre o embargo à obra de Agostinho Manuel de Vasconcelos, intitulada Vida y acciones del rey Don Juan el Segundo, sobre o «descrédito em que se encontrava a nação perante as estrangeiras por causa das histórias que nelas se escreviam a seu propósito, não respeitando as leis rigorosas que deveriam guardar» ${ }^{212}$. Por algum motivo os bolandistas desenvolveram a diplomática, Fernández Pulgar escreveu Sigalión, os historiadores se sangravam em protestos de escreverem apenas a verdade e a lei cominava penas contra todos os falsários, quer fossem de moeda, selos, documentos, «drogas, pedras e medicinas ${ }^{213}$.

O falso encontrava-se facilmente nas Relaçôes ${ }^{214}$, em Histórias Gerais ou em documentos destinados a fazer prova, estando já alguns historiadores precavidos quanto a alguns falsos, embora os falsários se adaptassem a contornar a nova crítica documental ${ }^{215}$.

Forjou um cronicão (Julio Caro Baroja, Las falsificaciones, pp. 104-105). É autor, entre mais de 200 obras, de Beroso de Babilonia en Chaldea, distinguido del Beroso de Viterbo en Italia: con la chronologia de los reyes antiquissimos de Asiria, y Babilonia. Valencia: por Geronimo Vilagrasa, 1673. Pellicer, no entanto, acabou por se converter à história crítica (Jesús Villanueva López, Política y discurso historico, pp. 199 s., onde trata de «El Pellicer de madurez»).

${ }^{211}$ Diogo Ramada Curto, O discurso politico em Portugal (1600-1650). Lisboa: Universidade Aberta, 1988, pp. 81 s; António de Oliveira, "A censura historiográfica no período filipino. Uma nota para o seu estudo", in idem, Movimentos sociais e poder, pp. 159-171; Maria Teresa Esteves Payan Martins, A censura literária em Portugal nos séculos XVII e XVIII, pp. 373 s. Em 1646 foi dado parecer negativo à impressão da obra de Traiano Boccalini, Comentarii sopra Cornelio Tacito, que corria manuscrita, em virtude da «malignidad» que continha sobre «Carlos V, Filipe II e, de modo geral, contra os espanhóis» (Fernando Bouza, El libro y el cetro, p. 27, onde se encontram examinados outros exemplos).

${ }^{212}$ Reproduzo em síntese a partir do parecer publicado em António de Oliveira, «Para a história do embargo à publicaçáo da obra de D. Agostinho Manuel de Vasconcelos», in idem, Movimentos sociais e poder, p. 155. A historiografia de Espanha, ao tempo de Filipe IV, acabou por ficar dependente do Conselho de Estado da monarquia (Enrique García Hernán, «Construcción de las Historias de España...», pp. 154 s.).

${ }^{213}$ Gaspar Barreiros, Censuras, fls. Cij e Ciij.

${ }^{214}$ Hospital das Letras, p. 218.

215 Ed. Fueter, Historia de la historiografia, p. 362. Falsos eram igualmente muito textos de autores com autoridade, a começar por D. Francisco Manuel de Melo. João Franco Barreto, na entrada que redigiu sobre D. Francisco Manuel para a sua Bibliotheca Luzitana, colocou a verdade acima da amizade ao denunciar a verdadeira autoria de La Victoria del Hombre, achaque furtivo que contagiou também, por exemplo, o bispo, estadista e inquisidor Sebastiāo César de Meneses, entre muitos outros em Portugal e Espanha, por exemplo. Com efeito, na Summa Politica encontram-se "vários passos retirados ou plagiados de Ramírez de Prado. Por outro lado, mais de 60\% da obra é decalque de um tratado de Scipione de Castro", segundo Martim de Albuquerque, Um percurso da construção ideológica do Estado, pp. 147 e 155, apresentando o confronto entre textos em pp. 203 s. E já em 1947, por exemplo, Costa Pimpão denunciava "Um plágio de Francisco Joseph Freire (Cândido Lusitano)», Biblos, vol. XXIII, tomo I, Janeiro-Abril de 1947, pp. 203-290. Para La Vitoria del Hombre, vide Jean Colomés, D. Francisco Manuel et la littérature française, pp. 491-511. Para outros deslizes de Melo, Valeria Tocco, «Andanças do barroco: apontamentos sobre Giovan Battista Marino e Portugal», in Estudos para Maria Idalina Rodrigues, Maria Lucília Pires, Maria Vitalina Leal de Matos, pp. 931-933. Doença que sofreram, antes da fixação dos direitos de autor, os próprios historiadores, estando apontados, no que diz respeito à história de D. Sebastiāo, alguns casos em Joaquim Veríssimo Serrão, Itinerários de el-Rei D. Sebastiāo (1568-1578). Lisboa: Academia Portuguesa da História, 1987, 2a ed., p. 14. 
Um destes tipos de falsificação, embora ingénuo em relação aos subsumidos nos exemplos anteriores, encontramo-lo ao tempo das alteraçóes em Portugal de 1637-1638, precisamente quando o conde de Basto negociava com Olivares o tipo de perdão a conceder aos revoltados. O conde de Basto argumentou historicamente a favor de um perdão geral sem excepçóes, que desejava que fosse concedido, mas a prova documental de um perdão deste tipo que apresentou foi facilmente rebatida como falsa pelos acessores de Olivares, senão por ele próprio, até pela biblioteca que possuía, caindo a possibilidade de invocar um exemplo anterior ${ }^{216}$.

Foram as «muito falsas opinióes» que corriam sobre os acontecimentos de Catalunha, segundo D. Francisco Manuel, que o levaram a escrever o seu livro, supondo ser capaz de fazer conter o amor ou o ódio das facçóes ideologicamentente divergentes ${ }^{217}$. Proeminalmente, adverte o leitor para náo continuar a folhear o livro, se não for a verdade que procura. A matéria de deleite novelesco havia ficado de fora, ao contrário da Epanáfora Amorosa $^{218}$.

A verdade em história, dadas as implicaçóes morais que se extraía dos exemplos, não dizia respeito apenas aos factos. Segundo Morcillo, a força para impor a moralidade era tanto maior quanto o autor era reconhecido como «orador de talento, prudentíssimo e versado na vida pública ${ }^{219}$. E, naturalmente, tido como verdadeiro. A sua autoridade representava uma das primeiras forças para ser imposta a moralidade, dado que o historiador não actuava ao modo de confessor ${ }^{220}$, deixando ao leitor a conclusão da experiência que apresentava, tornando-se o leitor em co-autor: «yo con lo que refiero, tú con lo que persuades», senten-

${ }^{216}$ António de Oliveira, «Levantamentos populares do Algarve em 1637-1638», in Movimentos sociais e poder, p. 592. Um dos conselheiros de Olivares nestas matérias seria Francisco de Rioja, falecido em 1659. É relativamente fácil encontrar dados não fidedignos em obras de caracter histórico de então, por vezes simplesmente forjados. Ainda do tempo de D. Francisco Manuel é a Chronica da Companhia de Jesu no Estado do Brasil e do que obrarão seus filhos nesta parte do Novo Mundo [...]. Lisboa: na officina de Henrique Valente de Oliveira, 1663, de Simáo de Vasconcelos (1597-1671), que por vezes sofre deste achaque, para além, ao mesmo tempo, de ter sido censurada depois de impressa (Zulmira Santos, «Em busca do paraíso perdido: a Chronica da Companhia de Jesu do Estado do Brasil de Simão de Vasconcelos, S. J.», in José Adriano de Feitas Carvalho, dir., Quando os frades faziam História. De Marcos de Lisboa a Simão de Vasconcellos. Porto: Centro Interuniversitário da Espiritualidade, 2001, pp. 145-178).

${ }^{217}$ Hospital das Letras, p. 195. Vide, a propósito, Antoni Simon i Tarrés, Les orígenes Ideològics de la Revolució catalana de 1640. Barcelona: Publicaciones de l’Abadia de Montserrat, 1999.

${ }^{218}$ Para a «história verdadeira», respeitando a verdade, e a fingida, vide a introdução de José Adriano de Carvalho a Francisco Rodrigues Lobo, Corte na Aldeia. Introdução, notas e fixação do texto de José Adriano de Freitas de Carvalho. Lisboa: Presença, 1992.

${ }^{219}$ De Institutione, p. 4, segundo texto transcrito, de onde aproveitamos, por Maria Teresa Amado, A Lingua do Ver, p. 234, n. 15. Mesma ideia em S. José, Geronimo de, Genio de la Historia, ibidem, pp. 381-382 e $384-$ 385; a autora publica também a versão manuscrita, de 1639, cotejada com a impressa.

220 Christian Lazzeri, «Os moralistas franceses do século XVII: a supremacia do amor-próprio e do interesse», in Alain Caillé, Christian Lazzeri, e Michel Senellart, dirs., História crítica da Filosofia Moral e Política. Lisboa: Editorial Verbo, p. 308; Jean Lafond, «Le champ littéraire des formes brèves», textes établis, presentés et annotés par [...], in Jean Lafond, dir., Moralistes du XVII siècle. Paris: Éditions Laffont, 1992, pp. 55 s., que se inicia com a rubrica "Sénèque et Tacite, modèles sans lendemain». 
ciava D. Francisco Manuel de Melo ${ }^{221}$. O mesmo sucedia para a conduta política. Verdade nos factos e verdade na doutrina deles extraída.

Mas o que era a verdade? Dentro da filosofia popperiana, só nos é permitido falar numa «aproximação à verdade», ninguém estando seguro de que «algo seja verdadeiro» ${ }^{222}$, embora haja hoje novas medidas de verosimilhança ${ }^{223}$. Com menos fundamentação, sem dúvida, mas citando Séneca, já Méndez Silva, em 1639, no entanto, explicitava que «quem trabalha por não errar está mais próximo da verdade» ${ }^{224}$, embora pela mesma época (1637), Descartes considerasse que «mesmo as histórias mais féis» «omitem quase sempre as mais baixas e menos ilustres circunstâncias, donde resulta que o restante náo parece tal qual é» ${ }^{225}$.

Para não cair no erro, o historiador tentava ser, com exemplos formais em séculos anteriores, "um escrivão da verdade»: "La verdad es la que dicta, yo quien escribe», convence-se D. Francisco ${ }^{226}$. E para a conhecida gravura que o primo elaborou para rosto de $D$. Teodósio, D. Francisco Manuel encontrou um dístico que duplicava o sentido da imagem, sobressaindo a ideia, para o que agora nos importa, de que «pinta a Verdade o que lhe dita a Memória» ${ }^{227}$. Noutro local, afirma: «Hablo como historiador, según las noticias de lo que he visto y oído", ao evitar pronunciar-se, embora pintor de almas, sobre a integredidade de certo personagem ${ }^{228}$. «Vi por miz ojos», «oy despues por mis oydos», insiste em Astrea Constante, invocando acontecimentos da batalha do Canal, em $1639^{229}$.

Mas aqui, no ver e ouvir, começam as primeiras dificuldades. D. Francisco Manuel sabia muito bem que a informação dos olhos podia ser bem duvidosa, sobretudo quando averiguada pelo temor ${ }^{230}$, como reconhecia que os mesmos factos podiam ter versóes diferentes ${ }^{231}$. Mas era "com o socorro dos olhos», com o testemunho ou intervenção, que «a faculdade do entender, acima do sentido do ver, fortificava o juizo ${ }^{232}$, tornando certo e

${ }^{221}$ Historia de los movimientos, p. 66.

${ }^{222}$ Kurt Hübner, Crítica da razão cientifica. Lisboa: Ediçốes 70, 1993, p. 179. Para a verdade formal como construto, Sottomayor Cardia, Racionalismo, consciência metodológica, 2007, pp. 98 s.

${ }^{223}$ Hermínio Martins, "Verdade, realismo e virtude» in Conhecimento prudente para uma vida decente: Um Discurso sobre as Ciências revisitado. Boaventura Sousa Santos, org. Porto. Ediçōes Afrontamento, 2003, pp. 386-387.

${ }^{224}$ Prólogo de Vida y hechos heroicos del gran condestable de Portugal D. Nuño Alvarez Pereyra.

${ }^{225}$ Renato Descartes, Discurso do Método, p. 9.

${ }^{226}$ Historia de los movimientos, p. 72. Em história militar, os soldados, forçosamente, eram "como testemunhas da verdade" (Francisco de Brito Freire, Nova Lusitânia, história da guerra brasílica. Lisboa: na officina de Joam Galram, 1675, Ao leitor). A história já foi entendida "como narrativa dos acontecimentos testemunhados» (Isabel de Barros Dias, Metamorfoses de Babel. A historiografia ibérica, sécs XIII-XIV. Construçóes e estratégicas textuais. Lisboa: FCG/FCT, 2003, p. 381).

${ }^{227}$ Cartas, pp. 246-247.

${ }^{228}$ Historia de los movimientos, p. 154; D. Teodósio, pp. 43-44.

${ }^{229}$ Astrea Cconstante, fl. 113v Por volta de 1605, também Atanasio de Lobera, com o intuito de escrever a sua Corónica grande el Reyno de Galicia, tinha por desejo «ver por vista de ojos las cosas que ay en el reyno de Galicia dignas de Historia [...]». Trascrevemos de Fernando Bouza, «Dar Galicia y el gallego a la imprenta», p. 10.

${ }^{230}$ Historia de los movimientos, p. 382.

${ }^{231}$ Epanapforas, p. 374.

${ }^{232}$ Demonstración, fls. 1-1v. Para o sentido da verdade em D. Francisco, vide Joel Serrão, «Introdução", Epanaphoras, pp. XXXIII-XXXIV. 
evidente o que o historiador narrava, tornando a História uma ciência. Dos sentidos e da percepção, os conceitos e os juízos.

O nome de ciência, segundo D. Francisco Manuel de Melo, «só cabe onde há certeza e evidência», embora o senso comum entenda que "toda a doutrina que se aprende e ensina parece ciência» ${ }^{233}$. A muitos dos saberes aplica D. Francisco a palavra ciência. Assim, a nova "guerra reduziu-se a termos de ciência», a conhecimento como regulaçáo: «a ordem alcança mais do que a fortaleza», reproduzindo saber antigo ou a própria experiência ${ }^{234}$. A previsão não pode assentar em «discursos sobre matérias incertas» ${ }^{235}$, como expóe em estilo breve e frases concisas.

Para escrever certezas no domínio da História, disciplina que Descartes inclui nas «Diversas consideraçóes sobre as ciências» do Discurso do Método, devia recorrer-se à aplicação geométrica e numérica. «De todas as ciências humanas verdadeiras, é a Matemática a que tem a maior reputação, dado que nas outras ciências se prova com a força da razão, enquanto que a Matemática recorre à infalibilidade das demonstraçóes, que consistem em conta, peso e medida» ${ }^{236}$. Com esta transcrição não literal, não é difícil encontrar a matriz galénica da natureza como um livro escrito em caracteres matemáticos. Como Copérnico (1473-1543) ${ }^{237}$, Bacon (1561-1626) ou Galileu (1564-1642), D. Francisco está voltado para a experiência, que para si é História, de que a invenção, «uma nobre parte do talento das pessoas», se por um lado lhe permite, tradicionalmente, traçar nos livros «figuras, disfarces, tropos e símbolos» ${ }^{238}$, por outro, recorrendo a alegorias, pode reduzir «as linhas, círculos, corpos e ângulos» da matemática às diversas nomenclaturas militares de "linhas, circunvalaçóes, corpos e baluartes com seus ângulos», para além da correspondência das escalas geométricas e do tesouro dos números. A nova frente contra os castelhanos deu-lhe oportunidade, por volta de 1663-1664239, de quantificar despojos, demonstraçáo matemática irrefutável da declaração especulativa que antes havia feito.

Para esta modernidade na demonstração da História, teria contribuído o Padre Baltasar Teles (1595-1675), filósofo antes de se tornar historiador, de quem D. Francisco Manuel se declara amigo e discípulo ${ }^{240}$. Conhecedor profundo de Aristóteles, soube deixar influenciar-

${ }^{233}$ Hospital das Letras, pp. 266-267.

${ }^{234}$ Historia de los movimientos, pp. 333 e 194. Sobre o novo exército, Epanaphoras, pp. 178-184. «No século XVII, a palavra ciência [...] tendia a designar qualquer corpo de conhecimento correctamente constituído (isto é, o conhecimento de verdades universais e necessárias)» como entende Steven Shapin, A Revolução Centífica, p. 27, nota.

${ }^{235}$ Historia de los movimientos, p. 182.

${ }^{236}$ Demonstración, fls. 1-1v.

237 «Por isso disse bem a nosso intento aquele clérigo da Polónia - Copérnico, ou como lhe chamam - que a Terra e os homens era sempre o que andava ao redor, não já o céu, o Sol nem as estrelas» (Escritório Avarento, p. 28. Na fala do Vintém.

${ }^{238}$ Hospital das Letras, p. 189.

${ }^{239}$ Batalhas: Ameixial, 1663; Castelo Rodrigo, 1664; Montes Claros, 1665. Sobre batalhas da Restauração vide, entre outros: Gabriel do Espírito Santo, Restauração 1640 / 1668. Colecção História de Portugal. Guerras e campanhas militares. Lisboa: Quidnovi, 2008.

${ }^{240}$ Cartas, pp. 502-513. Texto redigido para a História Geral de Ethiópia a Alta, ou Preste Joam, e do que nella obraram os padres da Companhia de Jesus composta na mesma Ethiopia, pelo Padre Manoel d'Almeyda [...] abreviada com nova releyçam, pelo Padre Balthezar Tellez. Coimbra: na officina de Manoel Dias, 1660 (há ediçóes modernas). Baltasar Teles é autor também da Chronica da Companhia de Jesu na Provincia de Portugal; $e$ 
se "pelos sábios e pensadores profanos da sua época», na expressão de José Sebastião da Silva Dias, o qual o considera também «a cabeça mais livre e lúcida da Companhia de Jesus, desde a morte de Pedro da Fonseca, até à quarta década do século XVIII ${ }^{241}$.

E se, no Hospital das Letras, D. Francisco andava de candeias às avessas com Descartes, provavelmente, segundo Teresa Amado, pela oposição acção-racionalidade ${ }^{242}$, na Visita das Fontes explicita já a aquisição do conhecimento a partir da dúvida que passará a ser um método $^{243}$.

Com estes pressupostos, pode causar estranheza a crítica que lhe endereçou, a propósito da Guerra de Cataluña, Pujol y Camps em 18 de Abril de 1886, denunciando inverdades que continha ${ }^{244}$.

A veracidade da obra decorria da frequente afirmação nesse sentido do autor e do facto dele ter participado nos acontecimentos, embora o tenha feito só numa parte do final de 1640, na trajectória do marquês de Los Vélez de Saragoça a Tarragona, sendo Melo preso pouco depois de 24 de Dezembro ${ }^{245}$.

O conteúdo da crítica de Pujol y Camps, feita dentro de um modelo historiográfico com conteúdos e conceitos prevalecentes ao tempo em que escreveu, é bem conhecido, como também se sabe a estupefacção de Vítor Balaguer (1824-1901), a quem coube responder ao discurso académico onde foi proferido ${ }^{246}$, e as reacçóes de defesa ${ }^{247}$.

do que fizeram, nas conquistas d'este reyno, os religiosos que na mesma Provincia entràram [...]. Lisboa: Paulo Craesbeeck, 1645-1647, 2 vols. Trata-se de «uma leitura exageradamente providencialista da história», segundo Nuno Gonçalves da Silva, Baltasar Teles, cronista da Companhia de Jesus, in José Adriano de Feitas Carvalho, dir., Quando os frades faziam História. De Marcos de Lisboa a Simão de Vasconcellos, p. 98.

241 José Sebastião da Silva Dias, Portugal e a cultura europeia (sécs. XVI a XVIII), «Biblos». Coimbra: Faculdade de Letras, vol. XVIII, (1952), p. 254. (Há reed. recente: Porto, Companhia das Letras, 2006). Vide ainda Edgar Prestage, D. Francisco Manuel de Mello, pp. 32-33, onde se encontra também o desenvolvimento da matemática em Santo Antão.

${ }^{242}$ A representação do poder, p. 49.

243 Visita das fontes, pp. 243, 552 (n. 349). Outra aparente influência, D. Teodósio, p. 44. Sobre o ambiente português seiscentista em relação a Descartes, vide, com bibliografia, António Alberto Banha de Andrade, "Descartes em Portugal nos séculos XVII e XVIII", in idem, Contributos para a história da mentalidade pedagógica portuguesa. Lisboa: INCM, 1982, pp. 169 s.

${ }^{244}$ Melo y la revolución de Cataluña en 1640. Discursos leidos ante la Real Academia de la Historia en la recepción pública de D. Celestino Pujol y Camps el día 18 de Abril de 1886. Madrid: Imprenta y Fundación de Manuel Tello, 1886; uma apreciação crítica sobre Pujol, in J. H. Elliott, La rebelión de los catalanes, pp. 526-527.

${ }^{245}$ Historia de los movimientos, pp. 235, 310 e 319. Los Vélez saiu de Saragoça em 8 de Outubro de 1640. Ia já em Tarragona, a caminho de Barcelona, quando o general recebeu oficialmente a comunicaçáo do sucedido em Portugal no primeiro de Dezembro e a ordem para prender alguns dos comandos portugueses do seu exército, contando-se entre eles D. Francisco Manuel. A prisão em Castela e as vicissitudes por que então passou não lhe permitiram que escrevesse de imediato a relação dos acontecimentos de que inicialmente havia sido incumbido. Em 1645, porém, com maior distanciamento dos sucessos e num contexto político ao avesso, foi capaz, como escreve, de expor aos pés do Papa «as vigílias de alguns anos de estudo, juntas em um livro» (Cartas, p. 111). Da prisão em que se encontrava havia solto uma das obras primas em termos literários centrada na história da guerra da Catalunha, das origens à batalha de Montjuic.

246 Celestino Pujol y Camps, Melo y la revolución de Cataluña en 1640, p. 101. Víctor Balaguer é autor de Historia de Cataluña y de la Corona de Aragón: escrita para darla a conocer al pueblo recordándole los grandes hechos de sus ascendientes en virtud, patriotismo y armas y para difundir entre todas las clases el amor al pais y la memoria de sus glorias pasadas. Barcelona: Salvador Manero, 1860-1863, 5 vols. 
A Guerra de Cataluña contém erros, muitas vezes devidos às fontes que utilizou e que os novos editores assinalam, contém silêncios, pequenos anacronismos e uma ideia de estrutura, mas não a que propôs Pujol, continuando a ser, para além de um modelo literário, uma boa fonte histórica que, como todas, tem de ficar sujeita aos cânones da crítica histórica por parte de quem a pretende aproveitar ${ }^{248}$. Mal feito fora que ao longo de mais de três séculos e meio não tivessem surgido novidades quanto à matéria. O que importa salientar, naturalmente, é o valor histórico no momento em que foi redigida. E quanto a este aspecto, o juízo está feito por Joan Estruch, o qual exarou: «estamos en condiciones de afirmar que la obra de Melo es sustancialmente verídica, la más verídica e imparcial de cuantas se escribieron entonces sobre aquellos hechos. Sólo pueden reprochársele de que algunos de ellos no son imputables a Melo, sino a las fuentes de que se servió» ${ }^{249}$.

Julgamento que parece ser final e que se encontra no sentido das intençóes declaradas por D. Francisco Manuel de Melo como historiador, ao procurar seguir, a exemplo da Poética, as «leis severas e rigorosas que não faltam à História, tanto nos preceitos dos antigos, como crítica dos presentes» ${ }^{250}$.

8.

Os possíveis erros e falsidades contidas em alguns textos históricos podiam surgir por muitas razóes. Uma delas, bastante corrente, era devida à adulação, "enfermidade própria dos que historiam» ${ }^{251}$, no entender de D. Francisco, embora, por sua conta, na Epanáfora Triunfante, descarte à partida a doença: «Eu conto os casos como elles forão, pella pauta da verdade; não como quererão que fossem a adulação ou o queixume» ${ }^{252}$. A necessidade de medrar, de editar obras ou de escrever por encomenda particular, ou simplesmente a paixão, eram ídolos táo poderosos que levavam os homens, como se exprimiu D. Francisco, «a sacrificar por eles as coisas mais preciosas que temos, que são a vida e o entendimento» ${ }^{253}$. Um destes exemplos que aponta no Hospital das Letras é o de Malvezzi em duas obras, tendo-lhe valido uma delas uma série de mercês, postos e honras ${ }^{254}$.

${ }^{247}$ Jacinto Octavio Picón, «Introducción» de Historia de los movimientos, separación y guerra de Cataluña. Uma apreciação recente (1996) favorável da Guerra de Cataluña, de Melo, em Cepeda Adán José, "La historiografía...", pp. 802-804.

248 «A obra de Melo não é uma obra histórica: é antes a manifestação de uma ideia política habilmente desenvolvida» (Celestino Pujol y Camps, Melo y la revolución, p. 37).

${ }^{249}$ Vida y obra, p. 3. A obra clássica de hoje sobre a revolta de Catalunha é a de J. H. Elliott, La rebelión de los catalanes. Este autor adverte que Melo «depende demasiado da su imaginación y no es de fiar», mas remete apenas para Celestino Pujol y Camps.

${ }^{250}$ D. Teodósio, p. 43.

${ }^{251}$ Cartas, p. 85.

252 Epanaphoras, p. 375.

${ }^{253}$ D. Teodósio, p. 243.

${ }^{254}$ Hospital das Letras, pp. 261-262. Os técnicos de saúde do hospital diagnosticaram e prognosticaram grave padecimento a um dos textos, denominado Sucesos principales de la Monarquia de España en el año de mil $i$ seiscentos $i$ trinta $i$ nueve. Madrid: en la Enprenta Real, 1640. A outra obra, que guindou o autor a embaixador na Grã-Bretanha 
Pela doença da lisonja, no entanto, roçou D. Francisco Manuel em 1638, ainda jovem, na dedicatória da Política Militar, mas, como acentuou Teensma, «mostra-se sereno, prudente e sincero $»^{255}$ no discurso proferido por volta de 1660-1662 na Academia dos Generosos sobre «el descontentamento de algunos autores quejosos de los príncipes, por falta de premio» ${ }^{256}$. A maturidade a prevalecer. A história da sua vida prova que tinha asco à lisonj $\mathrm{a}^{257}$ e podemos afoitamente aceitar que não pintou com ódio ou amor ${ }^{258}$, «não escreveu com pena parcial a algum partido» ${ }^{259}$ e não calou o erro ou o louvor ${ }^{260}$, procurando ser objectivo, referindo os factos como sucederam ${ }^{261}$, não impondo, apenas escrevendo-os, para seguir tópicos da sua auto-avaliação ${ }^{262}$. Imagem de "independência e serenidade» ${ }^{263}$ que, contudo, nem sempre humanamente conservou, como ao desculpar, em nome de antiga colaboração, alguns actos do marquês de Los Vélez, em relação aos quais fontes cataláes (ou mesmo castelhanas) dos mesmos factos não confirmam ${ }^{264}$, ou «fingir uma atitude de imparcialidade desmentida pelo seu silêncio unilateral», no ajuizar de Colomés ${ }^{265}$. Por vezes disfarçava com o estilo, quando as circunstâncias o exigiam, embora procurando manter «uma cristã e verdadeira imparcialidade, entre amigos e inimigos» ${ }^{266}$. Mas muito mais parcial

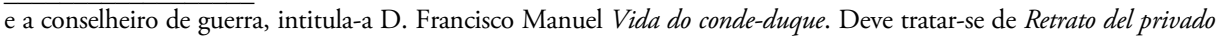
christiano politico: deducido de las acciones del Conde Duque. Nápoles: por Octavio Beltran, 1635. Traduçâo do italiano. Há edições de Bolonha e Nápoles, onde se acrescenta: escrito alla Catholica Maestá di Fillipo III il Grande. Sobre a embaixada extraordinária a Inglaterra, vide J. H. Elliott, El conde-duque de Olivares, pp. 629-632.

${ }^{255}$ Don Francisco Manuel de Melo, p. 117.

${ }^{256}$ Obras Métricas, vol. II, pp. 1020-1025.

${ }^{257}$ Cartas, p. 82.

${ }^{258}$ Tácito, p. 111.

${ }^{259}$ Epanapforas, p. 252.

${ }^{260}$ Historia de los movimientos, p. 73.

${ }^{261}$ Historia de los movimientos, p. 154.

${ }^{262}$ D. Teodósio, p. 45.

${ }^{263}$ Benjamin Nicholaas Teensma, Don Francisco Manuel de Melo, p. 115.

264 Bem identificados na edição de Historia de los movimientos, a cargo de Joan Estruch, por exemplo. Considere-se que D. Francisco Manuel de Melo, em D. Teodósio, p. 146, deixou exarado, em relaçáo ao quinto marquês de Los Vélez y Molina, D. Pedro Fajardo Zúńiga y Requesens: "Tão grata memória devo aos seus benefícios que, sem receio, prefiro a gratidão a qualquer juízo, com grande desculpa por tấo boa causa violentado». D. Francisco Manuel de Melo, no local referido, dá-o apenas como «adiantado-mor do reino de Múrcia, homem notável destes tempos e que, podendo ser conhecido pelas suas virtudes, o foi mais pelas suas desgraças em todos os postos que ocupou até seu recente e malogrado fim». O general e vice-rei da Catalunha, por sinal, não tinha experiência militar (J. H. Elliott, La rebelión de los catalanes, p. 440). Noutro local, o mesmo autor considera que «as suas credenciais eram sobretudo de natureza política, mas ia ter à sua disposição técnicos militares para o aconselharem». Por outro lado, "Olivares julgaria que seriam precisos mais dotes políticos do que militares para a pacificação de Catalunha» (J. H Elliott, El conde-duque, pp. 641-642; resumimos a citação). O próprio D. Francisco Manuel de Melo explicitamente declara que foi escolhido "para aconselhar e assistir» Los Véllez e que detinha grande poder «em aquelle Exercito, igual ao dos mayores Cabos delle; sem meu parecer mandava hum só passo, quem o governava» (Epistola, p. 124).

${ }^{265}$ La critique et la satire, p. 44.

${ }^{266}$ D. Teodósio, p. 45. 
se comportou D. Luís de Meneses, acima referido, em relação a D. Afonso VI, não obstante reivindicar o prémio da veracidade ${ }^{267}$.

Algumas das obras de História escritas por D. Francisco foram solicitadas pelo poder régio ou o próprio rei. Matérias públicas, na maioria dos casos, onde poderia estar ancorado um sentimento pátrio em tempo de guerra. Acrescente-se à encomenda do poder a possível rogativa de amigos em relação a outros trabalhos, como poderia ter sido o caso de El Fenix de Africa, se não foi o rei, ${ }^{268}$ ou a própria deliberação de se oferecer para redigir relaçóes de actos militares levados a efeito por comando amigo, como a relaçáo da armada que a Companhia Geral do Comércio enviou ao Brasil em $1649^{269}$ ou outras tentativas historiográficas ${ }^{270}$.

De qualquer modo, na apreciação destas obras não nos podemos alhear da sentença que ele próprio proferiu em relação a outros: os historiadores que «escrevendo por mandado de príncipes desarrazoados, não vemos que fizessem Historia, mas uma apologia ${ }^{271}$. Os que escreviam, sublinhe-se, "por mandado de príncipes desarrazoados", o que parece fazer crer que não eram assim os seus patrocinadores, régios ou não.

9.

Um dos trabalhos aceites por D. Francisco Manuel foi o de historiar os fundamentos da nova dinastia entronizada em Dezembro de 1640, cuja memória merecia, a todos os títulos,

${ }^{267}$ Quase ao chegar ao fim a obra, explicita no início do livro XII do $4^{\circ}$ volume da História de Portugal Restaurado: «[...] tiveram princípio novas contendas políticas, tão embaraçadas e perigosas, que puseram em contingência a sua conservação. E como esta matéria seja a mais alta de todas as que contém esta história, e foi o principal motivo que nos persuadiu a abraçar a dificultosa empresa de escrevê-la, deitamos de parte todos os outros sucessos, para não interrompermos o fio de negócio tão grave [...]» (p. 409).

${ }^{268}$ El Fenix de Africa (1648) foi escrito a pedido do próprio rei, na opinião de Teensma (Don Francisco Manuel de Melo, p. 138) ou, de acordo com a indicação que este autor dá de Prestage, do conde camareiro-mor João Rodrigues de Sá. A cota que indica a este propósito para Edgar Prestage, D. Francisco Manuel de Mello, pp. 229-230, não corresponde à asserção.

${ }^{269}$ Relaçam dos sucessos da armada que a Companhia geral de Comercio expediu ao Estado do Brasil, o ano passado de 1649. Lisboa: na Officina Craesbeekiana, 1650. Encontra-se republicada por Joel Serrão, Epanaphoras, pp. 540551. Relaçáo publicada anónima, a qual, como decorre da análise interna do documento, parece ter sido escrita, como sugere Teresa Amado, por um novo D. Francisco Manuel ou, então, é preciso duvidar da atribuição da sua autoria (Maria Teresa Amado, A representação do poder, pp. 106-107). O general da armada da Companhia Geral do Comércio era o segundo conde de Castelo Melhor, D. João Rodrigues de Sousa, a quem Melo havia prometido «ser aqui o gazeteiro de seus sucessos» (Cartas, p. 390, datada de 28 de Abril de 1650; sobre o assunto, vide também pp. 393 e 472-473).

${ }^{270}$ Segundo Barbosa Machado, a obra que ficou manuscrita intitulada Relaciones del oriente, que "continha os sucessos do primeiro ano do governo na Índia do Conde de Linhares», foi «dedicada ao Duque de Maqueda, e Naxera, a cuja instancia compoz esta obra» (Bibliotheca Lusitana, tomo II, p. 187).

${ }^{271}$ Hospital das Letras, p. 250. A acusação envolve sete historiadores, os quais nomeia. Por volta de 1614 , teorizava Luis Cabrera de Córdoba: «Las historias estan por cuenta, y cargo de los Principes». É o Príncipe que elege o historiador e lhe dá o tema. "La materia no la inventa el historiador, ni la escoge». O historiador póe a prudência e a eloquência (De Historia, fls. 16v e 27-27v). 
que fosse fixada de imediato, fora da instituição do cronicado-mor do reino ${ }^{272}$. As dinastias, como os edifícios, assentam em alicerces e foi por estes que a história da nova dinastia reinante principiou. Coube a D. Francisco Manuel, com efeito, a incumbência pessoal de historiar a vida de D. Teodósio, II de nome e VII duque de Bragança. A do príncipe D. Teodósio, morto em 13 de Maio de 1653, ficará a cargo de Joâo Nunes da Cunha, por mandato da rainha regente ${ }^{273}$ e a do rei $\mathrm{D}$. João IV será prosseguida por D. Francisco Manuel.

Da história de D. Teodósio, elaborada por D. Francisco Manuel, conhecem-se apenas os três primeiros livros da primeira parte, os quais, como é bem sabido, encontram-se editados, traduzidos em português, desde 1944, supondo-se, com algum fundamento, que se trata apenas de uma parte do texto que foi redigido ${ }^{274}$.

Os críticos têm sido unânimes em considerar o texto destes três livros como trechos de uma obra de história de qualidade inferior às outras do mesmo género do autor ou, quando muito, "pouco acrescenta ao valor de Melo como historiador»" ${ }^{275}$.

Podem ter razão. Não teria sido esta, porém, a opinião de D. Francisco, ao tempo do entusiamo dos começos, o qual esperava que $D$. Teodósio viesse a ser «uma das mais notáveis escrituras da nossa pátria» ${ }^{276}$. «La obra será grande por la materia», repetirá em carta ao Dr. Juan Baptista Moreli, pseudónimo de autor conhecido ${ }^{277}$. Tinha razão D. Francisco, a julgar pelo projecto que elaborou.

D. Teodósio não é propriamente uma biografia, mas antes uma história de Portugal, como o subtítulo bem explicita: História própria e Universal do reino de Portugal e suas conquistas [... ]» ${ }^{278}$ e escrita, como depois o autor dirá do Tácito Português, com maior razão, fora do costume das "proluxas crónicas pasto da vulgaridade» ${ }^{279}$.

${ }^{272}$ Era cronista-mor, desde 9 de Janeiro de 1644, Frei Francisco Brandão (Joaquim Veríssimo Serrão, $A$ historiografia portuguesa, vol. II, p. 30; António da Silva Rego, "Introdução» in Monarquia Lusitana, parte quinta. Lisboa: INCM, 1976, pp. [XI s.]. Foi autor da $5^{\mathrm{a}}$ e $6^{\mathrm{a}}$ parte da Monarquia Lusitana, referente ao reinado de D. Dinis. O reinado de D. Joáo IV, da autoria do cronista-mor Frei Francisco de Jesus (nomeado em 1681), só ficou pronto a publicar em Setembro de 1687, data da censura e aprovação. Veio a editar-se, no entanto, apenas em 1940-1942 e 1958 (Rafael de Frei Jesus, Primeiro volume da $18^{a}$ parte da "Monarchia Lusitana». Coimbra: Biblioteca da Universidade de Coimbra, vol. I, 1958; Rafael de Frei Jesus, Segundo volume da 18a parte da «Monarchia Lusitana; manuscrito original publicado por M. Lopes de Almeida, Damiāo Peres, César Pegado [editores, também, do Primeiro volume]. Coimbra: Biblioteca Geral da Universidade, vols. I e II, 1940-1942). Rafael de Jesus foi ainda autor da $7^{\text {a }}$ parte da Monarquia Lusitana, correspondente a D. Afonso IV, publicada em 1683, para além de outras obras.

$2731^{\circ}$ conde de S. Vicente, antigo vice-rei da Índia e membro da Academia dos Generosos. Segundo Edgar Prestage, chegou a juntar, para o efeito, «alguns documentos dos quais se aproveitou o Pe Manuel Luís [1608-1682], da Companhia de Jesus, para a vida do mesmo príncipe que compoz na lingua latina» (Edgar Prestage, D. Francisco Manuel de Mello, p. 319, n. 4). O príncipe D. Teodósio nasceu em 8 de Fevereiro de 1634. Vide, a propósito, Fernando Castelo-Branco, «Teodósio, Príncipe D.», in Joel Serrão, dir., Dicionário de História de Portugal.

${ }^{274} \mathrm{O}$ original da primeira parte estaria pronto para ser impresso em 28 de Março de 1678, data das licenças da Inquisição, segundo Machado, Barbosa, Bibliotheca Lusitana, vol. II, p. 186, o qual informa estar o manuscrito na posse do irmão, D. José de Barbosa. Quem teria procurado obter a licença de publicação?

${ }^{275}$ Joaquim Veríssimo Serrão, A historiografia portuguesa, vol. II, p. 181.

${ }^{276}$ D. Teodósio, p. 19.

277 Cartas, p. 278. Trata-se de pseudónimo de Frei Fulgencio Leitão.

${ }^{278} \mathrm{O}$ título da primeira parte da obra, segundo o códice de Évora, que Augusto Casimiro publica em fac-símile e transcreve em tradução (D. Teodósio, p. 25), é o seguinte na língua original: Theodosio del nombre segundo, Principe 
Os reis, que neste exemplo são apenas uma ideia, não têm vida privada, ou pelo menos tem afectação pública a sua vida privada. A sua vida reflecte a vida da nação, assim como esta espelha a do príncipe. Por estas razóes, a vida deste é a vida da nação ${ }^{280}$. No caso presente era forçoso que assim fosse, dado que os reis que governaram na maior parte do tempo da vida de D. Teodósio deixaram de ser reis de Portugal, estando simbolicamente abolidos da sua história, em consonância com a cronologia dinástica reinante, como pictograficamente continuam ainda hoje, e desde 1655, ausentes da galeria de retratos régios da sala de actos grandes da Universidade de Coimbra ${ }^{281}$. Assim, os reis naturais sempre governaram Portugal, incluindo obviamente D. Teodósio, sendo o direito à coroa, como era, indiviso ${ }^{282}$.

A nova história de Portugal, cuja área se estende pelos quatro continentes, é também, ao mesmo tempo, uma história integrada no mundo. Ao mesmo tempo que expóe a história de Portugal e suas conquistas onde quer que estas se localizem, são feitas igualmente referências aos principais acontecimentos mundiais, seleccionados com os critérios do seu tempo, como que ao modo de uma história pontifícia, de que no momento estava sob crítica a Quinta parte de la Historia pontifical y catolica [...] por Fray Marcos de Guadalaxara y Xavier ${ }^{283}$.

de Bragança: duque setimo de su Estado, natural Señor de los Portugueses. Historia propria, e Universal del Reino de Portugal, y sus Conquistas en Europa, Africa, Asia, y America, con sufficiente noticia de los sucessos del mundo, el tiempo de la vida deste Principe. Escrita de orden del muy Alto, y muy Poderoso Rey nuestro señor Don Juan el Quarto, su Hijo, y Padre d la Patria. Ofrecida a su Magestad, por D. Francisco Manuel. Parte Primeira. Dividida en ocho libros. Quare? Año Christiano 1648 P. Mortalia vivunt ope calami. Todo debaxo la correccion de la $S^{\text {ta }}$. Me . Iglesia Catli. ${ }^{a}$ Ap. ${ }^{\text {ca }}$ Romana (D. Teodósio, p. 151).

279 Tácito, p. 1. Continua a citação: «depois que passado o tempo da contemporização cada pena se fez atrevida». Da "guerra brasílica em brevíssimo modo» tratou na Epanáfora Triunfante (Epanaphoras, p. 482).

280 «Os príncipes não têm nenhum dia como homens» (Astrea, p. 95).

${ }^{281}$ Os retratos régios da Sala dos Capelos, até D. João IV, foram pintados em Lisboa por Carlos Falch (ou Falque) a partir de 1655 (Vergílio Correia, Obras. Vol. I. Coimbra: por Ordem da Universidade, 1946, pp. 178 e 187-189; Vítor Serrão, A pintura Proto-Barroca em Portugal (1612-1657), vol. II, Os pintores e as suas obras. Coimbra: Faculdade de Letras, 1992, p. 489). Frei Rafael de Jesus (1687), na 18a parte da Monarchia Lusitana, que trata da "História del Rei Dom João $4{ }^{\circ}$ », começa, no tomo I, com as origens da Casa de Bragança e nela integra os aspectos da história do período filipino que seleccionou. Ainda em 1730 (?) se escrevia: «O tempo, em que se introduzirão os tres Reys de Castella [...] não tem historiador particular em Portugal (Chronica do muito alto, e muito esclarecido principe D. Sebastiáo [...]. Composta por Manoel de Menezes [...]. Segunda parte. Lisboa: na Officina Ferreyriana, 1730, prólogo; encadernada com a primeira parte, com paginaçáo separada). Mas em 1734, pelo menos, já se encontra a indicação sumária da história dos Filipes por ordem cronológica antes do desenvolvimento do primeiro de Dezembro (Fernando de Meneses, Historiarum Lusitanorum ab anno MDCXL usque ad MDCLVIII [...], tomus prior. Lisboa: in Aedibus Josephi Antonii da Sylva, Regiae Academiae Typographi, 1734).

${ }^{282}$ Como escreveu D. Francisco Manuel, «muitos, durante muito tempo, supuseram Teodósio desejoso de passar ao irmáo [D. Duarte] a condição, os encargos e as esperanças» (D. Teodósio, p. 142). O que levou Manuel da Veiga Tagarro, em imagem poética, a ter D. Teodósio cometido como que um estelionato (Helena Barbas, "Laura de Anfriso", cap. IV, 2.1.2, nas Odes).

${ }^{283}$ Marcos Guadalajara y Javier, Quinta parte de la historia pontifical y catolica [...]. Madrid: por Melchior Sanchez, 1652. Outra edição, da mesma data e local, segundo parece. De 1630 há duas ediçóes (Quinta parte da historia pontifical), datadas de Barcelona e de Madrid, com aprovação de 28 de Junho de 1629. Consultámos a edição do título que começámos a desenvolver, acrescentada por Iuan de Tamayo Salazar, depois da crítica a que foi submetida em virtude da brevidade com que foram tratados alguns assuntos. D. Francisco Manuel utilizou a obra de Frei Marcos em as Epanaphoras, p. 204, e louvou através de um soneto, onde parece aludir a alguma crítica, o 
Manuel de Faria e Sousa, por exemplo, preferiu fazer uma história de Portugal por continentes. Mas uma das críticas que lhe foi feita a propósito da sua Europa Portuguesa foi precisamente de que nela «no ay sino portugueses y más portugueses». A resposta de Faria e Sousa aos seus críticos nada teve de cosmopolitismo, característica de D. Francisco, defendendo-se pela centralidade do enunciado do título da obra. Mal feito fora, como responde, se, por exemplo, o Padre Juan Mariana, que prometia no título da sua obra «una Historia General de Espańa», «despues cuydasse en ella de poco mas que de lo tocante a Castilla ${ }^{284}$.

Destas críticas, e ainda bem, estava livre D. Francisco Manuel, colocando-se como que acima de uma história nacional ${ }^{285}$, tendo projectado para o tempo de D. Teodósio três volumes ou partes, cada uma dividida em oito livros: o primeiro abrangeria o período de $1567^{286}$ a 1579; o segundo, de 1580 a 1582; o terceiro, de 1582 a $1630^{287}$. Seriam, assim, 62 anos de história de Portugal, tantos quantos os da vida de D. Teodósio ${ }^{288}$, embora os livros que se encontram editados, "confrontados com os acontecimentos do mundo e das nossas

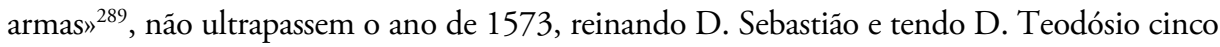
ou seis anos incompletos ${ }^{290}$.

«Doctor Bavia» (Luís Bavia, 1555-1628) autor da 3a e 4a partes da referida história (Obras Métricas, vol. I, p. 28). A mesma metodologia de integraçáo enuncia o título do capítulo II da chamada segunda parte da Crónica de D. Sebastiāo, pretensamente atribuída a Manuel de Meneses: «Do estado do Mundo, e do Reyno de Portugal, quando ElRey D. Sebastiấo passou o governo delle, e do que ordenou logo no princípio» (Officina Ferreyriana, 1730). Também Rafael de Jesus na obra acima referida, apresenta no cap. $9^{\circ}$ do livro 3, numa metodologia de integrar os principais sucessos do mundo na história de Portugal, uma «Sumaria recordação dos Princepes Christãos, Ecclesiasticos, e seculares; e dos sucessos com q̃ governarão seus estados desde o anno de 604. ate o de 1640". Enumera Sumos Pontífices, Imperadores do Ocidente, Reis Católicos de Espanha, Reis Cristianíssimos de França e Reis da Gran Bretanha. No cap. 10 continua com outras enumeraçóes (Inquisidores Gerais, Prelados, Governadores...). Como já em 1597 e 1609 havia feito Frei Bernardo de Brito ao agrupar por «títulos», dentro dos capítulos, «as «cousas do mundo» e, antes dele, com melhor integraçáo, Pedro de Mariz em Dialogos de varia historia, desde a primeira edição (1594). Os capítulos dos volumes da Monarquia Lusitana editados em 1632 e 1650 deixaram de apresentar os referidos epílegos comparativos.Vide infra, n. 346.

${ }^{284}$ Manuel de Faria e Sousa, Europa portuguesa. Lisboa: Antonio Craesbeeck de Melo, 1678, p. 26. Trata-se do primeiro volume, «segunda edicion correta, ilustrada, y añadida en tantos lugares, y con tales ventajas que es labor nuevo por su autor".

${ }^{285}$ A história eclesiástica, sobretudo a apoiada nas collectiones conciliorum, «est universalle en ce qu'elle se pense en termes tridentins d'histoire regroupant dans le seine de l'Eglise l'histoire depuis a naissance du Christ», em contraste com a nova história das pátrias que se estava a desenvolver. Para França, Bernard Chédozeau, «L'histoire religieuse au $\mathrm{XVII}^{e}$ siècle. L'histoire de l'Église, au histoire ecclésiastique, et les collectiones conciliorum", Littératures Classiques. Le temps au XVII siècle. Toulouse, vol. 43 (Automne 2001), p. 180.

${ }^{286}$ D. Sebastiáo tomou conta do governo em 20 de Janeiro de 1568, ao fazer 14 anos (D. Teodósio, p. 205). D. Teodósio teria nascido no ano anterior ou alguns dias depois de D. Sebastiāo ter assumido o governo. Sobre a data do nascimento de D. Teodósio, vide infra, n. 295.

${ }^{287}$ D. Teodósio, pp. 46-47.

${ }^{288}$ Morreu em 26 de Novembro de 1630.

${ }^{289}$ D. Teodósio, p. 47.

${ }^{290}$ D. Teodósio, p. 240 (onde afirma ter D. Teodósio sete anos). Ao longo do texto, no entanto, este período cronológico é ultrapassado ao tratar, por exemplo, dos filhos e netos do sexto duque de Bragança, D. João, e de D. Catarina, com excepçáo da primeira linha (D. Teodósio, p. 148). D. Duarte, por exemplo, morreu em Março de 1627. 
A parte final do texto publicado de D. Francisco Manuel, que diz respeito ao tempo de D. Sebastião, teve por base, como explicitamente refere, um manuscrito de João Cascão, cronista do senhor D. Duarte ${ }^{291}$, intitulado Relação da jornada de El-Rei D. Sebastiáo, quando partiu da cidade de Évora, o qual se encontra editado desde 1887, sendo fácil averiguar o modo como o utilizou ${ }^{292}$.

D. Sebastião chegou à Tapada de Vila Viçosa no dia 12 de Fevereiro de 1573, depois da visita ao Algarve. D. Teodósio náo teria ainda cinco anos completos, mas D. Francisco Manuel atribui-lhe sete e fá-lo participar nas cerimónias da recepção régia efectuada no palácio, tendo, pela primeira vez, beijado a mão régia, pedida «com extrema serenidade [...], que depressa convinha alcansá-la quem táo cedo devia obedecer-lhe ${ }^{293}$. Um começo de poder simbólico de quem um dia herdará a suposta sucessão, depois de libertado de Alcácer-Quibir ${ }^{294}$.

$\mathrm{Na}$ narrativa de João Cascão, tal como se encontra publicada, D. Teodósio não aparece citado entre os presentes na cerimónia da recepção, nem em outro momento. D. Francisco é seguro no aproveitamento da crónica, embora, por exemplo, a duração da viagem náo coincida com o indicado por Cascão nem seja confirmada pelo estudo dos itinerários régios ${ }^{295}$. Teceu, no entanto, judiciosas consideraçóes sobre os objectivos da

${ }^{291}$ Filho do infante D. Duarte, irmão de D. João III, e de D. Isabel, filha do quarto duque de Bragança, D. Jaime. Morreu em 28 de Novembro de 1576. D. Sebastião fez a viagem enquadrado por D. Duarte e o duque de Aveiro, para além dos fidalgos da comitiva.

${ }^{292}$ Conhecem-se duas versóes, uma da Casa do Cadaval e outra dos Arquivos Nacionais/Torre do Tombo (AN/TT), ambas actualmente publicadas. A primeira encontra-se em Francisco de Sales Loureiro, Uma jornada ao Alentejo e ao Algarve; as alteraçóes das linhas de força da política nacional; texto do cronista João Cascão. Lisboa: Livros Horizonte, 1984, edição que utilizámos. O texto da TT está publicado na Revista das Sciências Militares, vols. II (1886), vol. IV (1887), vol. V (1887) e vol. VI (1888), por António Alfredo Barjona de Freitas e, José Manuel Rodrigues, estando explicitadas as diferenças entre os dois manuscritos por Sales Loureiro (pp. 14-16 e 19-20), cujas indicaçōes bibliográficas seguimos (pp. 10-11 e 19). Esta versão, no que diz respeito ao Algarve, foi republicada, com abundante referência histórica e bibliogáfica, por Alberto Iria, «D. Sebastião e o Algarve, donde partiram os primeiros socorros para o cerco de Mazagão", in idem, Da importância geo-política do Algarve na defesa maritima de Portugal nos séculos XV a XVIII. Lisboa: Academia Portuguesa da História, 1976, pp. 48-160. Trata-se da primeira viagem de D. Sebastiâo ao Algarve no inverno de 1573. Esteve outra vez no Algarve, no Outono deste ano, estando já em Sagres em 19 de Setembro e, em Évora, de regresso, em 9 de Outubro.

${ }^{293}$ D. Teodósio, p. 240.

${ }^{294}$ Os que serviam, começavam a fazê-lo «na idade do pião» (João de Barros). D. Teodósio, que acompanhou D. Sebastião a Alcácer-Quibir (1578), tinha «onze anos incoados», segundo Frei Rafael de Jesus, Primeiro volume da $18^{a}$ parte da "Monarchia Lusitana», p. 66). D. Francisco Manuel faz nascer D. Teodósio II em 1567 (D. Teodósio, p. 46), mas na p. 157 escreveu 1568, às cinco horas da tarde de 28 de Abril (segundo a edição em português), e expôs o seu horóscopo "que eu próprio vi por obséquio do seu Augusto neto». É esta a data que anda divulgada, estando certo o Santo do martirológico romano, tendo sido seguida por António Caetano de Sousa, o qual neste e outros pontos se baseia em D. Francisco Manuel de Melo, como parece, o que leva a conjecturar ter tido presente um exemplar manuscrito de D. Teodósio (António Caetano de Sousa, História genealógica da Casa Real Portuguesa. Nova edição revista por M. Lopes de Almeida e César Pegado, vol. VI. Coimbra: Atlântida - Livraria Editora, 1947, pp. 81 e 174). Frei Rafael de Jesus, porém, que emendou algumas datas expostas por contemporâneos dos acontecimentos, fá-lo nascer em 1567, observando a propósito da correcção da data do casamento de D. Teodósio (1603): «Fio mais a obrigação do cuidado q̃ o escreve, q̃ aos descuidos da confiança, q̃ o pratica» (ibidem, p. 46).

${ }^{295}$ D. Francisco afirma que a viagem de D. Sebastião demorou «alguns meses» (p. 238). A narrativa de João Cascâo começa em 2 de Janeiro e termina em 14 de Fevereiro, cerca de mês e meio, portanto. Cf. Joaquim 
viagem ao Algarve, que ainda hoje devem ser ponderados ${ }^{296}$, embora julgue que se tivesse revelado inútil, uma vez reduzida «a touradas, jogos de canas e gastos extraordinários, sem que nunca se descobrissem os benefícios que visara ${ }^{297}$. Não se esqueceu de indicar que na volta passou pela vila de Cheles, em Castela ${ }^{298}$, considerando a incursão um capricho de jovem, a qual Barbosa Machado explica como forma de encurtar caminho ${ }^{299}$.

Para além da história de Portugal integrada na história de D. Teodósio, D. Francisco Manuel prometeu ainda a história do período da vice-realeza da princesa Margarida, o que poderia ser culminada na história posteriormente desenhada de D. João IV, na vida deste enquanto duque. $\mathrm{O}$ estudo dos reis de Portugal desde a sua fundaçáo, considerados pela via da expressão e ensino através dos símbolos, havia-o começado já ${ }^{300}$, devendo surgir, assim, um conjunto de trabalhos sobre os reis de Portugal e da nação, um novo serviço prestado ao poder reinante e à pátria, que bem poderia, segundo solicitou no Prólogo de D. Teodósio, suprir os defeitos da sua vida. Petição e interesse, no entanto, que não afectou a sua imparcialidade de historiador e que não lhe trouxe, afinal, ganhos visíveis no andamento do processo criminal que lhe havia sido movido em 1644.

10.

Para que D. Francisco Manuel tivesse procurado historiar a vida de D. João IV, ou provavelmente até a vida de $\mathrm{D}$. Teodósio, foi necessário que tivesse ocorrido, como é óbvio, o movimento do primeiro de Dezembro de 1640, sobre o qual, para além do que se encontra em o Tácito, escreveu a sua prefiguração através de uma história dos movimentos sociais que o precederam.

Veríssimo Serrão, Itinerários de el-Rei D. Sebastião, pp. 264-277. Para a viagem de Setembro-Outubro, ibidem, pp. 298-300.

${ }^{296}$ D. Teodósio, p. 238.

${ }^{297}$ D. Teodósio, p. 237.

${ }^{298}$ D. Teodósio, p. 238.

${ }^{299}$ Memórias para a história de El-Rei D. Sebastião, parte III, cap. XX, p. 485, segundo citação de Francisco Loureiro (p. 75, n. 26), de onde aproveitamos. Cheles é um município raiano, na actual província de Badajoz. Era senhor de Cheles, segundo Cascão, «D. Francisco [Manuel] e sua mulher D. Teresa de Lima é irmá do alcaide de Mourấo, onde agora reside». Ao tempo do casamento do duque de Bragança, futuro D. João IV, Afonso de Lucena, morgado de Francisco de Lucena, estava casado com «Dona Maior, Senhora de Cheles (António de Oliveira Cadornega, Descrição de Vila Viçosa. Introdução, proposta de leitura e notas por Heitor Gomes Teixeira. Lisboa: IN/CM, 1982, p. 72). A mãe era aparentada com os duques de Bragança e do senhor de Cheles, D. Diogo Manuel, segundo documento transcrito por José Emídio Amaro, Francisco de Lucena. Sua vida, martírio e reabilitação. Subsidios para a história do reinado de D. João IV. Lisboa: Edição do Instituto para a Alta Cultura, 1943, p. 87.

${ }^{300}$ Em D. Teodósio, p. 236, refere o «tratado genealógico dos reis de Portugal». No segundo memorial ao monarca, publicado por Camilo, afirma: «Apenas tive notícia de que V. M. gostaria de ver escritas as vidas dos sereníssimos reis portugueses, que corressem com suas medalhas pelo mundo, logo me dispus a fazer a V. M este serviço; cuja execução esta bem próxima [...]». (Carta de guia de casados. Porto: Typ. Pereira da Silva, 1873, p. 28). E em D. Teodósio, p. 32, explicita: «Continuei logo compondo a história dos reis portugueses, que brevemente, espero, sairão à luz». 
Como é arquisabido, a primeira relação incluída no primeiro volume das Epanaphoras de varia Historia Portugueza tem por título Alteraçoens de Evora, conhecida também por Epanaphora politica Primeira. O texto constituiu, até há uns trinta anos, a melhor fonte sobre a revolta que estalou em Portugal em 1637. Cerca de um século depois de a Guerra de Cataluña sofrer a acusação de que se não tratava de uma obra histórica, a Epanáfora Política saltou para o palco dos levantamentos populares, muito em voga nos anos 60-70 do século passado, representando-se como um clássico de conflitos sociais ${ }^{301}$, os quais, como Melo os qualificou ao tratar das alterações de Évora, constituíram como que um "fausto \& elegante preludio, da redenção Lusitana» ${ }^{302}$.

Entre estas duas obras está a mesma personalidade que as concebeu. D. Francisco era um nobre e, como tal, em caso de conflito armado estaria sempre ao lado dos exércitos reais, que o mesmo é dizer da nobreza. Por ambas as obras, no entanto, perpassa uma humanidade que se insurge contra as prepotências do poder, advertindo-o bem das cautelas com que devia proceder para evitar conflitos como os que tratava.

Assim, por exemplo, a descrição que faz da reunião democrática dos revoltados em Évora, nomeadamente do funcionamento da congregação e do modo como que se convocavam, é justificada, no sentido da história madre da experiência política, "para que se veja até donde alcança a industria dos oprimidos: \& para que a todos os Príncipes sirva de aviso a fim de que cuidem de remediar a opressáo dos Vassallos, antes que elles se disponháo ao remedio della».

Clarividência de quem igualmente defendia a origem popular do poder, teoria comum ao tempo da circunstância, «embora alguns príncipes», esquecidos do pacto original, como sublinha, «fizeram crime aos vassalos do uso da razão», «julgando por uzurpadores da república todos aqueles que em si recolhem o poder que eles enjeitam, ou esperdiçam»" ${ }^{303}$.

Certamente que nesta obra de D. Francisco, como em outras de natureza histórica, há silêncios e alguns pequenos erros ou lapsos que hoje não são difíceis de apontar ${ }^{304}$. Sabe-se

${ }^{301}$ Neste domínio, escreveu Joan Estruch: «no encontraremos en la historiografía española o portuguesa de la época relato alguno que pueda comparársele» (Joan Estruch, "Historia social e historia personal en la Epanáfora Política, de F. M. de Melo", Boletín de la Biblioteca de Menéndez Playo. Santander: Sociedad Menéndez Pelayo, vol. LXXI, Enero-Diciembre, 1995, p. 104. Vide, também, Joel Serrão, "As alteraçōes de Évora (1637) no seu contexto social», in D. Francisco Manuel de Melo, Alteraçôes de Évora, pp. XIII s.

302 Epanaphoras, p. 151.

${ }^{303}$ Tácito, pp. 55-56.

${ }^{304}$ No Tácito, por exemplo, indica que Francisco de Lucena exercitara o lugar de secretário de Estado, em Madrid, durante 36 anos, número já corrigido para 26 anos, no cúmulo com o ofício de secretário das Mercês, por José Emidio Amaro, Francisco de Lucena, p. 143. Foi nomeado secretário de Estado no Conselho de Portugal em Madrid em 23 de Agosto de 1614, por aposentação no ofício do seu tio Fernão de Matos, sob condição de o monarca o poder mandar ir servir a Portugal outro ofício, sem indemnização, quando o houvesse por bem, assim como não tratar «das cousas tocantes a pessoas e casa do Duque de Bragança» (José Emídio Amaro, Francisco de Lucena, p. 97, publicando a carta de nomeação). Foi este secretário de Estado que em 1629 foi recebido no Porto com um motim (António de Oliveira, "Contestação fiscal em 1629. As reacçóes de Lamego e Porto", in idem, Movimentos sociais e poder, pp. 295 s.). Saiu de Madrid, para as diligências que lhe foram incumbidas na província de Entre Douro e Minho, em 28 de Novembro de 1629. Passou depois para a secretaria das Mercês, em Portugal, sendo colocado em 1631, no seu lugar de Madrid, Diogo Soares com o título de secretário de 
bem, por exemplo, qual a exacta tarefa que o corregedor de Évora executava quando o levantamento eclodiu em 21 de Agosto, a inventariação das fazendas. Beja, cidade, ao contrário do que aponta, também se levantou ${ }^{305}$ e conhecem-se agora, com alguma minudência, os nomes das terras que aderiram à contestação, mas não ainda, certamente, a sua totalidade ${ }^{306}$.

Tenha-se em conta que no tempo em que D. Francisco Manuel esteve em Évora, a correspondência oficial circulava de Lisboa para Madrid através de correios ordinários e extraordinários, pelo que não podia ter acesso a ela, sendo hoje em parte conhecida ${ }^{307}$. Nem táo-pouco acedeu à correspondência oficial sobre a preparação militar, embora tivesse observado em Badajoz o estado da força em prevenção, mas não, por muito retirado do caminho de Madrid, o que se passava na área do Conselho de Guerra sediado em Ayamonte, embora dele apresente alguns aspectos. Mas tinha informação, ou soube depois - D. Francisco escreveu uma dúzia de anos após os levantamentos e publicou o texto em 1660 - , que no reino do Algarve se estavam a passar acontecimentos de muito maior gravidade do que no reino de Portugal ${ }^{308}$. Para além do que observou e certamente ouviu, utilizou documentação da época, alguma da qual publica.

Évora, como se sabe, foi a primeira cidade a manifestar-se. Pelo exemplo dos começos, pela importância do lugar, nela residindo nobreza alta, entre ela um antigo dirigente do país, governador e vice-rei, o conde de Basto $^{309}$, assim como pela referida obra de D. Francisco Manuel, Évora tornou-se epónimo das alteraçôes, embora no Alentejo a situação social e política em Portalegre talvez tenha sido pior $^{310}$, havendo-se levantado mais de metade da área geográfica de Portugal continental, com ecos pelo menos nos Açores. Mas foi com a nobreza de Évora que o governo de Madrid abriu directamente diálogo.

D. Francisco Manuel tomou pessoalmente parte nestes acontecimentos em dois momentos distintos. Primeiro, como agente da Casa de Bragança sediado em Madrid,

Estado, Fazenda e Justiça. As alterações na divisão das secretarias foram levadas a cabo em Setembro deste ano. Para lapsos cometidos em D. Teodósio, vide n. 295 e texto da respectiva página.

305 Vide António de Oliveira, Poder e oposição politica em Portugal no período filipino (1580-1640). Lisboa: Difel, 1991, p. 170 e nota; António de Oliveira, Movimentos sociais e poder, p. 499, n. 58; e sobretudo Emília Salvador Borges, "O motim popular de Beja em 1637», Ler História. Lisboa, vol. 43, (2002), pp. 5-37, a partir da documentação camarária da cidade. Melo diz, primeiro, que Beja e Elvas "guardàrão inesperada moderação» para em seguida afirmar "que faltarão de seguir a opinião de toda a Provincia» (Epanaphoras, p. 67). Quanto a Elvas, o cabido, sé vacante, "contribuiu fortemente para que a cidade se não rebelasse, ao mesmo tempo que ajudou a pacificar os lugares levantados da área da sua jurisdição eclesiástica» (António de Oliveira, Poder $e$ oposição política, p. 170). Sobre a matéria, vide os índices dos meus trabalhos já referidos, voc. Elvas.

${ }^{306}$ António de Oliveira, Poder e oposição política, pp. 168 s., onde se publica um mapa dos levantamentos, depois reproduzido em mais do que um local.

${ }^{307}$ Há documentação referenciada por registo de correspondência ou por cotas de arquivo em Espanha que se perdeu ou se encontra por localizar.

308 Epanaphoras, p. 86. Vide, a propósito de todo o movimento António de Oliveira «Levantamentos populares no Algarve em 1637-1638", in idem, Movimentos sociais e poder, pp. 513-687.

309 Vide Rafael Valladares, Epistolario de Olivares y el conde de Basto (Portugal 1637-1638). [Badajoz]: Diputación de Badajoz, Departamento de Publicaciones, 1998.

310 António de Oliveira, «Levantamentos populares no distrito de Portalegre em 1637-1638», in idem, Movimentos sociais e poder, p. 499. 
entregou ao conde-duque e outras personalidades correspondência de D. João, duque de Bragança, a reiterar a sua lealdade no início dos levantamentos, não deixando de estar atento, como impunha a sua perspicácia e as funçôes que desempenhava, às atitudes de Olivares $^{311}$. A segunda deslocou-se a Évora, tendo estado também em Vila Viçosa, ao tempo em que acompanhou o conde de Linhares, sendo depois encarregado de transmitir oralmente ao governo de Madrid o resultado da missão em que esteve integrado e, certamente, a opinião sobre a situação, uma vez instado a pronunciar-se.

A ida a Évora no séquito do conde de Linhares explica-se pelo papel que recentemente havia representado em favor da casa de Bragança e pelas funçóes que temporariamente desempenhou junto do conde, quando este arribou a Málaga, vindo do vice-reinado da Índia.

Foi D. Francisco Manuel de Melo, andando embarcado na Armada de Portugal desde Outubro de 1636, o encarregado, nos finais do ano, de lhe prestar socorro ${ }^{312}$, acabando por servir na capitânia da Índia em Málaga e deslocar-se à corte de Madrid, autorizado por Linhares, em 20 de Janeiro de 1637, a fim de solicitar mercês pelos serviços prestados e despesa do acompanhamento militar de oito criados que levou ${ }^{313}$. Por esta altura era confidente do conde-duque ${ }^{314}$, lisonjeando-o na Política Militar en avisos de generales, assim como a "grandiosa casa de Linhares»" ${ }^{315}$, parecendo, deste modo, inculcar o desejo de um posto elevado a caminho do Brasil ${ }^{316}$, dado que, na data em que escreve Política Militar, o castigo dos exceptuados do perdão geral no movimento de 1637-1638 em Portugal estava decidido e praticamente terminado no tocante ao crime contra o Estado ${ }^{317}$.

${ }^{311}$ Epanaphoras, pp. 70-74. Melo diz ter «cartas para ElRey, Conde Duque, \& outros grandes Ministros de Portugal, \& Castella» (ibidem, p. 73).

${ }^{312}$ Cf. Bernat Vistarini, Francisco Manuel de Melo, p. 117.

${ }^{313}$ Edgar Prestage, D. Francisco Manuel de Mello, pp. 80-82 e documentos que publica. Acontecimentos cantados em epístola dirigida a D. Francisco de Quevedo («Epístola VI, La Fistula da Urania», Obras Métricas, vol. II, pp. 962-968).

${ }^{314}$ Assim refere o relatório do embaixador veneziano Giustiniani, correspondente aos anos de 1634 a 1638, publicado, em excerto, por Gregorio Marañon, El conde-duque de Olivares (La pasión de mandar). Madrid. Espasa Calpe, 1980, p. 109, n. 13. Notícia aproveitada já também por Colomès. Sobre a presença na corte nesta data, escreveu D. Francisco Manuel: «[...] neste tempo eu residia na corte, pretendendo com melhor fortuna para os negocios alheyos, que para os meus proprios, \& não sem algũa inteligencia, \& graça com grandes Ministros» (Epanaphoras, p. 73).

${ }^{315}$ D. Francisco deu a ler o manuscrito, antes de o publicar, ao conde de Linhares.

${ }^{316}$ D. Francisco tinha então trinta anos e era «de boa estatura» para militar, segundo se ajuizava quando um pouco mais novo (Edgar Prestage, D. Francisco Manuel de Mello, p. 440). Era mestre de campo de um terço de infantaria espanhola, havia ganho visibilidade política ao transmitir a Olivares as suas observaçóes sobre a revolta de Portugal em 1637 e o conde de Linhares ainda continuava a preparar-se para embarcar para o Brasil, sendo entáo tratado como «virrey y capitan general del Estado del Brasil, empresa y restauración de Pernanbuco». Ao mesmo tempo, aparece ainda, na dedicatória da Política Militar que estamos a seguir, como «Capitán Generale del Mar Océano, sucesor y lugar teniente de la Serenísima Princesa Margarita, en la Capitania General del Reyno de Portugal», para além do exercício de cargos palatinos. Havia sido, em tempos anteriores, governador de Tânger (1624-1628) e vice-rei da Índia por seis anos e alguns meses, cujo cargo havia terminado em 8.12.1635.

317 António de Oliveira, «Levantamentos populares do Algarve em 1637-1638», in idem, Movimentos sociais e poder, pp. 513-687. 
A guerra no interior da corte, que, como bem definiu D. Francisco, não era «menos crua, ou menos artificiosa, que a verdadeira guerra ${ }^{318}{ }^{3}$, venceu desta vez a oposiçáo existente nas secretarias dos assuntos portugueses em Madrid, tendo o conde de Linhares perdido a graça régia e D. Francisco Manuel, bem provavelmente, a crescença na graduação militar. Mais tarde, pelo menos em 1649, D. Francisco encarregar-se-á de explicar bem as facçôes políticas e as lutas entre os adversários que conduziram Linhares à desgraça ${ }^{319}$, o qual teve outros companheiros de infortúnio por vezes bem maior que o seu, no conjunto dos comandos enviados ou indigitados para o Brasi ${ }^{320}$.

Lutas cortesãs pelo poder em momento de revolta aberta entre o povo, cujos levantamentos demoraram muito tempo a serem apaziguados, a denotar a gravidade da situaçáo.

A pacificação das alteraçóes em Portugal e Algarve fez-se recorrendo a diversos processos, mas nunca os exércitos cantonados em Badajoz e Ayamonte entraram em Portugal como país a reconquistar, sujeitando-o à lei das armas, embora a defesa dos portos algarvios tivesse sido reforçada e, em certo sentido, a principal área revoltada do país (Alentejo e Algarve) acabasse por ficar envolvida por forças militares ${ }^{321}$.

Quanto à ocupaçáo do Algarve, Melo precisa que inicialmente foi acordado, com o governador do reino, «em que algũas companhias castellanas passassem o rio e se viessem alojar nos lugares maiores». O marquês de Valparaíso, um dos conselheiros de guerra de Ayamonte sob comando geral do duque de Medina Sidónia, pressionou a entrada, no entanto, de "seis mil infantes, em lugar das companhias que se lhe haviam consentido", actuando o duque de modo mais «rigoroso e absoluto» do que o de Béjar, em Badajoz ${ }^{322}$. Contingente de guarnição manifestamente exagerado, a julgar pelo que hoje se conhece, se bem que se temesse o socorro dos amotinados pela via marítima a partir de país inimigo de Espanha. Guarniçóes reforçadas estando já o reino do Algarve fiscalmente reduzido à situação anterior aos levantamentos.

A documentação disponível não permite quantificar quantos soldados espanhóis entraram no Algarve para reforço das guarniçóes dos portos, existindo, desde Filipe II, presídios militares estrangeiros em Portugal ${ }^{323}$, embora se conheçam alguns indicadores para certos lugares algarvios ${ }^{324}$. Sabe-se, no entanto, que o castigo dos revoltados, quanto aos

${ }^{318}$ Epanaphoras, p. 106.

319 «Fizeram-no General do Mar Oceano e foi gozá-lo em um castelo preso quatro anos, por culpas imaginárias, sem que tomasse posse, nem tal se pensasse» (Ecco politico, fl. 12v).

${ }^{320}$ Epanaphoras, pp. 104 s. É bem conhecido o que se passou com D. Fradique de Toledo Osório, marquês de Villanueva de Valdueza, ao recusar a segunda ida ao Brasil.

${ }^{321}$ António de Oliveira, «Levantamentos populares no Algarve», pp. 573-574.

${ }^{322}$ Epanaphoras, pp. 6, 136-137.

323 Jean-Frédéric Schaub, Le Portugal au temps du Comte-Duque d'Olivares (1621-1640). Le conflit de juridictions comme exercice de la politique. Madrid: Casa de Vélazquez, 2001, pp. 264 s. Recentemente (Novembro de 2009), o mesmo autor apresentou em Lisboa, em colóquio internacional sobre "Portugal na Monarquia Espanhola. Dinâmicas de integração e de conflito», um estudo sobre a matéria referente aos Açores. Para Coimbra, vide António de Oliveira, A guarnição castelhana de Coimbra ao tempo da realeza de D. António (1580-1595), em vias de publicação.

${ }^{324}$ Para Lagos e outros lugares, vide António de Oliveira, «Levantamentos populares do Algarve», pp. 577579. Foram previstos, inicialmente, dois mil homens para repressão e segurança dos portos, contingente depois diminuído. Muitos dos soldados, pelo menos, chegaram aos seus postos por mar. 
crimes de Estado, foi resolvido pela figura do perdão geral com exceptuados, sendo estes condenados pela justiça, embora em toda a área revoltada tivesse actuado a ameaça do «temor das armas»" ${ }^{325}$. No Algarve, por exemplo, actuou Pedro Vieira da Silva, «Doutor em leis e Desembargador dos Agravos», de quem Melo falou de modo muito comedido: «nesta ocasião deu grandes sinais da prudência e da modéstia com que havia de exercer o supremo lugar de Secretário de Estado, que agora exercita». Recorde-se que foi este secretário que interveio no aperto da prisão de Melo, em determinado momento, como acima referimos ${ }^{326}$.

Sendo assim, D. Francisco Manuel não participou militarmente na repressão das sediçôes de 1637-1638 em Portugal, como é óbvio, e a pacificação dos levantados, incluindo os do Algarve, não se fez através da força viva do exército espanhol ${ }^{327}$. Portalegre, por exemplo, foi convencida a submeter-se, precisamente sob argumento, oferecido pelo duque de Bragança, de ficar sujeita à lei das armas, se o exército tivesse de entrar em Portugal.

Não pode, por isso, D. Francisco Manuel de Melo ser acusado de que «eluda describir en forma dramática la represión de las tropas castellanas que acabaron violentamente con la sublevación de Évora», como já foi publicado por reconhecida autoridade sobre a vida e a obra de D. Francisco Manuel ${ }^{328}$. Ideia igualmente acolhida por outros especialistas, espaldada em textos de historiadores que não puderam utilizar a documentação hoje conhecida ${ }^{329}$.

Nunca o duque de Bragança, sob o ponto de vista formal, apoiou as alteraçóes, como seria de esperar. Pelo contrário, na opinião oficial do governo de Madrid, tendo mesmo conseguido que nas suas terras alteradas não houvesse exceptuados do perdão geral ${ }^{330}$. Outros senhores, que D. Francisco Manuel de Melo nomeia, actuaram também na pacificação das suas terras. E há mesmo um, que qualifica de "grande amigo» numa carta datada de 18 de Setembro de 1637 , que por sinal é seu parente ${ }^{331}$, que se propôs militarmente pacificar "os rumores populares», dispondo, ao que parece, de "pouca gente e mal disciplinada», havendo sido sensatamente dissuadido por Melo.

Em determinado momento da revolta, mas apenas em certo momento, os interesses da nobreza, como reconhece D. Francisco, eram iguais aos do povo, embora expressos de outra maneira. Não só a nobreza, como agência de controlo que era, não actuou com

\footnotetext{
325 António de Oliveira, «Levantamentos populares no Algarve.», pp. 563 s. O duque de Medina Sidónia, comandante general do exército que se encontrava em Ayamonte, não entrou no Algarve. Como bem diz Melo: «[...] se consultava cõ o Duque, que desde Ayamonte dispunha o que julgava mais conveniente» (Epanaphoras, p. 137).

${ }^{326}$ Vide, n. 98.

327 Os portugueses «fácilmente templaron su orgullo a vista de las armas de Mérida, año de treinta y siete» (Guerra de Cataluña, p. 196).

${ }^{328}$ Joan Estruch, «Historia social e historia personal en la Epanáfora Política», p. 91.

${ }^{329}$ Entre outros exemplos: Antonio Bernat Vistarini, Francisco Manuel de Melo, p. 121; R. A. Stradling, Felipe $I V, 1^{\text {a }}$ ed. inglesa, 1988, p. 241; I. A. A. Thompson, Guerra y decadencia: gobierno y administración en la España de los Austrias. Barcelona: Crítica, 1981, p. 191 (1 $1^{\text {a }}$ ed. inglesa, 1976); e o mesmo em José Ramos Coelho, História do infante D. Duarte. Lisboa: por Ordem e na Typographia da Academia Real das Sciencias, 1889, pp. 249-250; mais sensato, seguindo a Epanáfora Política, Luís Augusto Rebelo da Silva, História de Portugal nos século XVII e XVIII, tomo III. Lisboa: Imprensa Nacional, 1867, pp. 450 s.

330 António de Oliveira, «Levantamentos populares no distrito de Portalegre em 1637-1638», in idem, Movimentos sociais e poder", p. 501.

${ }^{331}$ Cartas, pp. 64-65. O amigo é D. Álvaro de Melo, segundo Antonio Bernat Vistarini, Francisco Manuel de Melo, p. 117.
} 
presteza, como outras estruturas repressivas do aparelho régio não agiram inicialmente ${ }^{332}$. Não admira, por isso, que Madrid passasse a temer de modo mais intenso a nobreza portuguesa, como tende a sugerir uma série de actos régios ${ }^{333}$.

Sendo assim, as informaçóes que D. Francisco Manuel diz ter prestado a Olivares, sendo forçosamente verdades, não se teriam revestido de favor especial em relação à casa de Bragança. A narrativa, datada de Setembro de 1649, é favorável, no entanto, a esta casa, chegando mesmo a considerar que em Vila Viçosa, ao tempo do levantamento, gente de fora não só aclamou «a liberdade do reino, mas a transferência dele, a seu Senhor», imagem de que se poderá duvidar ${ }^{334}$.

É possível, no entanto, que tivesse sido cauteloso quanto à nobreza em geral e sabe-se, a crer no que diz num dos memoriais enviados ao monarca, que chegou a transmitir ao duque de Bragança «os secretos e expedientes que se tomavam nas juntas e conselhos acerca» das alteraçóes $^{335}$. E fê-lo, saliente-se, em idade ainda jovem e em tempo que náo passava de «um requerente que em tudo dependia do bom semblante» do conde-duque, como se não esqueceu mais tarde de sublinhar ${ }^{336}$. Mas não é muito crível que Olivares, nos finais de 1640 ou nos inícios do ano seguinte, lhe recordasse que lhe não prestara em 1637 informação cabal, sem que disso tivesse resultado consequências gravosas para D. Francisco, entáo preso como comando militar de que se não teria inteira confiança, não voltando ao exército da Catalunha, uma vez solto. Deve ter-se em conta que D. Francisco Manuel parece que nunca gostou de Olivares ${ }^{337}$, apeado do governo em Janeiro de 1643, salvo talvez episodicamente em 1637, como referimos acima, ao contrário de Filipe IV, de quem fala, aliás, com alguma dorida simpatia em o Tácito ${ }^{338}$. Foi a seguir às alteraçóes que D. Francisco Manuel esteve preso em Lisboa, em 1638, por ordem do corregedor da cidade, devido a actos praticados ao tempo em que, como Mestre de Campo, recrutava em Lisboa para o terço de Martim

332 Para o papel da nobreza, com diferenças entre Alentejo e Algarve, vide António de Oliveira, «Levantamentos populares no Algarve em 1637-1638», in idem, Movimentos sociais e poder, pp. 549 s.

333 «Levantamentos populares no distrito de Portalegre em 1637-1638», pp. 501-502.

334 Epanapforas, p. 42. António de Oliveira Cadornega (Descrição de Vila Viçosa) conta com pormenor o sucedido, considerando a acçáo «uns risquicios» em relaçáo a Évora, mas não faz referência ao relato de D. Francisco Manuel, embora conhecendo-o. As pessoas que entraram de fora logo desapareceram, segundo conta. Cadornega chegou a Angola em 1639, com uns 15 anos. A pormenorização dos acontecimentos, a não tê-lo como "escritor fantástico" (p. 70), deve ter sido baseada em alguma fonte, possivelmente manuscrita, embora declare, em 1683, não aumentar o relato, "como testemunha de vista», por outro autor há pouco tempo (1660) ter tratado o assunto. E repisa: «Só digo do que vi e faz a meu propósito» (p. 102). E páginas anteriores, havia reiterado: «Que isto, que passou há mais de quarenta anos, haver em partes tão remotas quem o tenha no sentido como se o tivera presente, não são cousas estas que as forma a Ideia, senão quem o viu e teve juízo pera o discursar e ter na memória» (p. 91). Há memórias assim, ainda hoje, no Alentejo popular. O que miudamente escreve anteriormente, como as festas do casamento de D. João duque de Bragança, passou-se, no entanto, em 1633, havendo Cadornega nascido em 1624. Como as relata, alguém as viu por ele. Vide, sobre o casamento, Hipólito Raposo, Dona Luisa de Gusmáo. Lisboa: Empresa Nacional de Publicidade, 1947, Livro terceiro.

335 «Memorial a El-Rei D. João IV», in Carta de guia de casados. Nova edição, com um prefacio biographico enriquecido de documentos ineditos por Camillo Castello Branco. Porto: Typ. Pereira da Sylva, 1873, p. 18.

\footnotetext{
${ }^{336}$ Ibidem, p. 18.

${ }^{337}$ Epistola, p. 124.

${ }^{338}$ Tácito, pp. 50 e 84.
} 
Afonso de Ataíde, com destino ao exterior do país ${ }^{339}$. No decorrer desta situação teve de proceder à sua defesa, sendo conhecidos alguns documentos sobre a matéria, embora não esclareçam, com clareza, o crime de que foi acusado ${ }^{340}$.

11.

O século XVII historiográfico em Espanha acaba bem pela época em que sobe ao trono Carlos II (1665), tempo já dos «inovadores» ${ }^{341}$. A caminho destes, sem dúvida, estava já D. Francisco Manuel de Melo, falecido no ano seguinte ao de Filipe IV. O conservadorismo de D. Francisco já foi qualificado, por Óscar Lopes, «como inteligente e

339 «Em 1638 foi preso o Mestre de Campo do Terço de Lisboa (AGS, GA, m. 337, 6 de Março de 1638). Em 2 de Abril de 1638, o Conselho de Estado remeteu ao Conselho de Portugal uma sua pretensão (AHN, Estado, liv. 372, fl. 21v). Ao longo de alguns meses, esteve preso na Torre de Belém, onde escreve um soneto intitulado "Fuegos de la noche de San Juan», in Obras Métricas, vol. I, p. 65, soneto XCIII e Joan Estruch Tobella, "Cuarenta sonetos manuscritos de Francisco Manuel de Melo», Criticón, Université de Toulouse, 61 (1994), pp. 10-11, com o título Considera los fuegos de la noche de S. Juan, hablando con una dama. Desta fortaleza passou para o castelo de Lisboa, onde certamente se encontrava já antes de 14 de Agosto e, de certeza, em 20 de Outubro de 1638, data de um despacho do Conselho de Guerra e aceite e rubricado por Filipe IV (AGS, GA, m. 1325, doc. 335) e mesmo antes do dia 7 (Cartas, p. 74, já citado em Obras Métricas, vol. I, p. 65, nota). Da prisão (?) compôs um soneto «al rey Don Felipe el Grande por la victoria de Fuenterrabía" (7.9.1638), intitulando-o depois da Restauração apenas como "A un rey por una vitoria» (BNP, cód. 7644, soneto 9, p. 177; Joan Estruch Tobella, "Cuarenta sonetos manuscritos de Francisco Manuel de Melo», p. 10; Obras Métricas, vol. I, p. 30; o soneto está datado de Lisboa, mas não diz de onde: «Escrivióse en Lisboa, año 1638»); em 14 de Janeiro de 1639, o vice-rei manda ao provedor dos Armazéns que proceda, na forma do seu regimento, contra os oficiais e soldados que, tendo assentado praça nos mesmos Armazéns para servirem el-Rei, e tendo já recebido soldo, passaram à leva que fazia D. Francisco Manuel (JJAS, Collecção chronologica 1634-1640, p. 186). D. Francisco Manuel foi a Lisboa recrutar para o terço de que foi encarregado Martim Afonso de Ataíde (AGS, GA, m. 1325). Transcrevemos, com alteraçôes, uma anotação que redigimos para a primeira redacção do vol. VI de «Nova História de Portugal», editorial Presença, na parte que nos diz respeito, que se encontra no prelo. A maior parte dos documentos referenciados encontram-se aproveitados in Jean-Frédéric Schaub, Le Portugal au temps du comte-duque d' Olivares (1621-1640), 2001, pp. 282-283. Deparámos com os referidos documentos, sendo então alguns microfilmados ou transcritos, quando iniciámos os trabalhos que levámos a cabo sobre os levantamentos populares.

340 Acrescente-se que o monarca mandou ver o memorial, apresentado por D. Francisco, ao Conselho da Guerra em 14 de Agosto de 1638, relativo à prisão deste ano. O Conselho apreciou-o em Outubro de 1638. O rei, em 20 de Outubro, concordou com o Conselho, rubricando a sua decisão: «esta bien». Mas nada ainda ficou resolvido em definitivo, como diz a resoluçáo do conselho: «Aviendose conferido esta materia en el Consejo, el duque de Villahermosa dijo que por el de Portugal se avia dado quenta de lo referido a V Md y consultado a V Md por aquella via y que por ser leve culpa del suplicante para averle preso sendo V Md servido se dira lo que ay en ello theniendo aôra por conveniente que se de orden a la senora Princesa informe para que con mas noticia se sepa la causa de dicha prision y ajustado todo puede $\mathrm{V} \mathrm{Md}$ tomar la resoluçion que mas convenga a su real serviçio si bien el conoçimiento dello no le pareçe toca ni pertençe a este Consejo. El Consejo se conforma lo que diçe el duque.V Md mandara lo que fuere su real voluntad. En Md a [espaço em branco] de otubre de 1638». Seguem-se três rubricas, de oito membros que tinha o Conselho. D. Francisco Manuel estava bem preso por esta burocracia. Em 7 de Dezembro, porém, estava já solto, mas continuava no castelo ainda no dia 3, segundo a data das suas cartas. Em 25 de Dezembro são-lhe passadas cartas pelo vice-rei para recrutar em Pinhel e Viseu e, certamente, para outros lugares (Edgar Prestage, D. Francisco Manuel de Mello, pp. 468-469, docs. 40-42). Para 1639, vide, n. 20.

${ }^{341}$ José Cepeda Adán, «La historiografía», pp. 821 s; Jesús Villanueva López, Política y discurso historico, pp. $191 \mathrm{~s}$. 
dinâmico» ${ }^{342}$. O que equivale a considerá-lo um conservador com tendências viradas para o futuro, o que se comprova no campo historiográfico ${ }^{343}$.

A escrita da história do seu tempo, por onde andaria a história da própria vida, constituiu desde início uma das finalidades da nova situação de vida. Certamente que ao longo da sua actividade de historiógrafo perpassam concepçóes de providencialismo ${ }^{344}$, organicismo e pragmatismo, com cânones vindos da antiguidade e do humanismo. Soube, porém, aproveitar do seu tempo as novas figuraçóes que conduziram à formação do chamado estado Moderno e trazer para a compreensão da história, roçando as ideias da experiência e da matematizaçáo do real, uma imagem, onde a sombra e o claro marcam a cena, mas já como que pré-iluminada a fim de achar a verdade através de novos cânones, "procurando concertar a novidade e o exemplo», como se exprimiu no prefácio a $D$. Teodósio ${ }^{345}$. Por outro lado, aceitou afoitamente uma concepção de História de Portugal inserta no mundo ${ }^{346}$, abertura cosmopolita que demorará alguns séculos a desabrochar na modalidade de história comparada.

Adverte a "ciência prudente» de hoje, que a natureza, e não apenas o ser humano, tem historicidade. Em sentido diferente, mas que dele se pode aproximar, explicitava já D. Francisco Manuel que o «mundo era um animal vivente», mudando-se com «a idade, os costumes e a natureza».

As raízes da cultura, atravessando os sistemas, mergulham fundo na seiva das naçóes, "provindo o homem do tempo» ${ }^{347}$. Mas continua a ser a experiência mais recente, a história do nosso tempo, a que gostava de estudar D. Francisco Manuel de Melo, a que prepara o futuro, para o qual os homens, ainda hoje, têm dificuldade em passar, cerebralmente presos ao núcleo do pretérito. Incapacidade encoberta às vezes por uma harmoniosa retórica "vestida de palavras antes fermosas que úteis» ${ }^{348}$, explicava D. Francisco, cheio de sabedoria e experiência. Saber multímodo, em que a História e a Política, convivendo com outras muitas ciências, fizeram dele um homem cimeiro na cultura peninsular do século XVII.

342 Óscar Lopes, «D. Francisco Manuel de Melo», in Hernâni Cidade, dir., Os Grandes portugueses, vol. II. Lisboa: Arcádia, 1961, p. 80.

343 «[...] muitas vezes, os praticantes seiscentistas detinham tanto de antigo como de moderno» (Steven Shapin, $A$ revolução científica, p. 28).

${ }^{344}$ Sobre necessidade e contingência, vide Joel Serrão, «Introdução», in Epanaphoras, pp. LIV s.

${ }^{345}$ D. Teodósio, p. 43.

${ }^{346}$ Atitude vincada já, quanto às histórias de Portugal que correram impressas, em Pedro de Mariz (1594) e Frei Bernardo de Brito (1597), como acima referimos. A dificuldade em escrever uma história comparada de Portugal levou este último autor, embora explicite outra razáo para o facto, a elaborar uma história de Portugal «sẽ nenhũa outra mistura de historias estranhas», acrescentando-lhe, «em titulos particulares», "pella ordem dos annos, hũ epelligo géral das cousas do mundo». Lição de história que permitiria aos portugueses, a um tempo, adquirir conhecimento das "rellaçóes antigas» e "afeiçoá-los mais» «as cousas de seus antepassados, quando à vista das do mundo the conhecessem tão notoria ventagẽ» (Frei Bernardo de Brito, Monarchia Lusytana [...] parte primeira. Alcobaça: Mosteiro de Alcobaça, 1597, fl. 4v). Cf. supra, n. 283

${ }^{347}$ Ilya Prigogine, O nascimento do tempo. Lisboa: Ediçôes 70, 1999, p. 22.

${ }^{348}$ Epanaphoras, pp. 120-121. 
Relembrá-lo não é mais do que cumprir um seu desejo «de que algum vindouro, depois dos seus dias, honrasse o seu nome, quanto ele procurava, «eternizar \& engrandecer o dos passados ${ }^{349}$. Concluía então a apresentação da vida e obra de D. Manuel de Meneses. Forma não usual de terminar uma trágica narrativa de um naufrágio, a inculcar a resilência do autor, ao escrever em tempo "quase de outro mundo", o do Brasil do desterro, certamente em hora de desengano, mas já com outra força anímica dos inícios da desventura maior da sua vida, a qual o levava a não desejar nada do mundo «senão do que dele sobeja, o esquecimento» ${ }^{350}$. Dor superada pelo recurso à escrita ${ }^{351}$, de que os textos históricos, que procurámos percorrer, depois de tantos outros, são candeias da luz da verdade.

\footnotetext{
${ }^{349}$ Epanaphoras p. 272 (as primeiras aspas não reproduzem citação literal).

${ }^{350}$ Cartas, p.114, datada de 9 de Dezembro de 1645.

351 «[...] yo no soy el hombre / en que el rey quiera mandar» (Obras Métricas, vol. I, p. 138).
} 

Série

Documentos

Imprensa da Universidade de Coimbra

Coimbra University Press

2010

- U

C • 